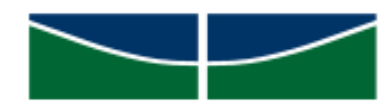

Universidade de Brasília

Faculdade de Economia, Administração, Contabilidade e Gestão de Políticas Públicas

Departamento de Ciências Contábeis e Atuariais

Programa de Pós-Graduação em Ciências Contábeis - PPGCont

Curso de Mestrado Acadêmico em Contabilidade

\title{
A INFLUÊNCIA DOS ATORES NO PROCESSO DE CONVERGÊNCIA DA CONTABILIDADE PÚBLICA BRASILEIRA AOS PADRÕES INTERNACIONAIS
}

Raquel Luz de Lima

Brasília, DF

2017 
Professora Doutora Márcia Abrahão Moura

Reitora da Universidade de Brasília

Professor Doutor Enrique Huelva Unternbäumen

Vice-reitor da Universidade de Brasília

Professora Doutora Helena Eri Shimizu

Decana de Pesquisa e Pós-graduação

Professor Doutor Roberto de Goés Ellery Júnior

Diretor da Faculdade de Economia, Administração e Contabilidade

Professor Doutor José Antônio de França

Chefe do Departamento de Ciências Contábeis e Atuariais

Professor Doutor Rodrigo de Souza Gonçalves

Coordenador de Pós-Graduação em Ciências Contábeis 
Dissertação apresentada ao Programa de PósGraduação em Ciências Contábeis da Universidade de Brasília (PPGCont) como requisito à obtenção do título de Mestre em Ciências Contábeis.

Linha de pesquisa: Impactos da Contabilidade no Setor Público, nas Organizações e na Sociedade.

Orientadora: Profa. Dra. Diana Vaz de Lima 
Ficha Catalográfica

LIMA, Raquel Luz de

A INFLUÊNCIA DOS ATORES NO PROCESSO DE CONVERGÊNCIA

DA CONTABILIDADE PÚBLICA BRASILEIRA AOS PADRÕES

INTERNACIONAIS/ Raquel Luz de Lima - Brasília, 2017.

117. f.

Orientadora: Profa. Dra. Diana Vaz de Lima

Dissertação (mestrado) - Universidade de Brasília, Faculdade de Economia, Administração e Ciências Contábeis e Atuariais - FACE. Programa de PósGraduação em Ciências Contábeis, Brasília, 2017.

Bibliografia.

1. IPSAS 2. Padrões Contábeis Internacionais 3. Teoria Institucional 4. Setor Público 5. Brasil. I. Universidade de Brasília. II. A Influência dos Atores no Processo de Convergência da Contabilidade Pública Brasileira aos Padrões Internacionais.

CDD - 


\section{A INFLUÊNCIA DOS ATORES NO PROCESSO DE CONVERGÊNCIA DA CONTABILIDADE PÚBLICA BRASILEIRA AOS PADRÕES INTERNACIONAIS}

Dissertação apresentada como requisito parcial à obtenção de título de Mestre em Ciências Contábeis do Programa de Pós-Graduação em Ciências Contábeis da Universidade de Brasília.

Data da aprovação: 25/01/2017.

BANCA EXAMINADORA:

Prof. ${ }^{\text {a }}$ Dr. ${ }^{\text {a }}$ Diana Vaz de Lima

Orientadora - UnB

Prof. Dr. Gileno Fernandes Marcelino Membro Examinador Interno - PPGCont/UnB

Prof. Dr. Paulo Carlos Du Pin Calmon Membro Examinador Externo - IPOL/UnB 
À família e aos amigos, em especial, pela grande compreensão durante esse período. 


\section{AGRADECIMENTOS}

À minha família pelo suporte e incentivo ao longo de todos esses anos, em especial ao meu irmão Rafael Luz de Lima pelo apoio incondicional.

À minha orientadora, Prof. Dra. Diana Vaz de Lima, que participou ativamente desta trajetória. O seu incentivo e as suas contribuições foram fundamentais.

Ao Prof. Dr. Ricardo Gomes que esteve sempre disponível para colaborar com questões conceituais e operacionais desta pesquisa. Precisamos de mais professores como você!

Aos amigos do mestrado, ninguém além de vocês aguentaria uma pessoa falar quase o tempo todo sobre assuntos relacionados ao mestrado. Dividir toda a experiência com vocês foi o que tornou esses dois anos, de certa forma, "mais leves".

Aos demais professores que compartilharam um pouco de seus conhecimentos permitindo-me chegar até aqui.

Ao Conselho Federal de Contabilidade e à Secretaria de Tesouro Nacional pela disponibilização de informações, e aos entrevistados pela colaboração com a pesquisa.

Aos membros da banca avaliadora pelas contribuições. 
"Aviso aos intelectuais: não deixem que ninguém vos represente."

Theodor W. Adorno 


\section{RESUMO}

Considerando que na perspectiva da análise institucional a mudança nos padrões contábeis mobiliza vários recursos organizacionais de natureza institucional, que são escassos os trabalhos empíricos no que diz respeito à implementação das IPSAS e que estas pesquisas não têm como foco os países latino-americanos ou não apresentam informações acerca de iniciativas recentes, o presente estudo teve como objetivo analisar a influência dos atores no processo de convergência da contabilidade pública brasileira aos padrões internacionais. Para tratar a questão da pesquisa, o estudo teve como suporte teórico a Teoria Institucional e a revisão da literatura sobre o tema. Em termos procedimentais, além da revisão bibliográfica e documental, foram realizadas entrevistas para a coleta de informações atualizadas do estágio recente da reforma da contabilidade pública no Brasil, e aplicado questionário semiestruturado para captar a interação dos atores envolvidos, além de outros itens relacionados com a promoção e condução do processo, utilizando-se o software NVivo para subsidiar a análise de conteúdo realizada. Ao apresentar o panorama do processo brasileiro, o estudo desenvolve uma linha temporal com os principais normativos sobre o tema, e ratifica os achados de estudos anteriores, apresentando o CFC e a STN como os atores mais influentes no processo de convergência da contabilidade pública brasileira aos padrões internacionais. $\mathrm{O}$ estudo mostra, contudo, que da perspectiva institucional os estímulos para a atuação desses atores na reforma da contabilidade pública brasileira foram diferentes: enquanto o CFC passou a abordar o assunto por pressões normativas relacionadas às demandas da própria profissão contábil, a motivação da STN pareceu estar mais relacionada com a necessidade de padronização e consolidação das contas públicas, sendo influenciada pelas demandas da FMI quanto à elaboração das estatísticas fiscais. Sobre a atuação dos tribunais de contas e dos demais atores, verifica-se a necessidade de maior envolvimento e interação, de forma que compreendam, aceitem e suportem a reforma em andamento para possibilitar a sua institucionalização.

Palavras-chave: IPSAS; Padrões Contábeis Internacionais; Teoria Institucional; Setor Público; Brasil. 


\begin{abstract}
Considering that from the perspective of the institutional analysis the change in accounting standards mobilizes various organizational resources of an institutional nature, that is scarce empirical work on the implementation of IPSAS and that those research does not focus on the Latin American countries or does not present information about recent initiatives, the present study aimed to analyze the actors' influence in the convergence process of Brazilian public accounting with international standards. In order to deal with the research question, the study had as theoretical support the Institutional Theory and the literature review on the subject. In procedural terms, in addition to the bibliographical and documentary review, interviews were conducted to collect updated information on the recent stage of public accounting reform in Brazil, and applied semi-structured questionnaire to capture the interaction of the actors involved, as well as other items related to the promotion and conduction of the process, using the software NVivo to subsidize the content analysis performed. In presenting the panorama of the Brazilian process, the study develops a time line with the main norms on the subject, and ratifies the findings of previous studies, presenting CFC and STN as the most influential actors in the convergence process of Brazilian public accounting with international standards. The study shows, however, that from the institutional perspective the incentives for these actors to act in the Brazilian public accounting reform were different: while the CFC began to address the issue through mimetic pressures related to the demands of the accounting profession itself, STN's motivation seemed to be more related to the need for standardization and consolidation of public accounts, being influenced by the IMF's demands for the preparation of fiscal statistics. Regarding the performance of the courts of accounts and other actors, there is a need for greater involvement and interaction, so that they understand, accept and support the ongoing reform to enable its institutionalization.
\end{abstract}

Keywords: IPSAS; International Accounting Standards; Institutional Theory; Public Sector; Brazil. 


\section{LISTA DE FIGURAS}

Figura 1- Pilares institucionais e variação de níveis: escolas ilustrativas ..............................25

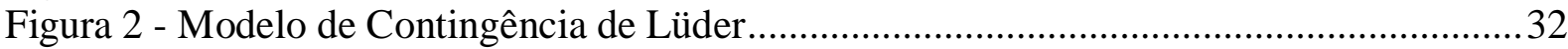

Figura 3 - Modelo Financial Management Reform (FMR) de Lüder ....................................33

Figura 4 - Modelo de Requisitos Básicos para o sucesso da implementação do regime de competência na contabilidade pública dos países desenvolvidos e em desenvolvimento.

Figura 5 - Interação entre grupos de fatores que tem influência sobre práticas contábeis

Figura 6 - Estrutura do Controle Governamental no Brasil......................................................40

Figura 7 - Ordem de observância dos normativos de Contabilidade Pública no Brasil. ..........62

Figura 8 - Linha Temporal dos Principais Normativos da Contabilidade Pública Brasileira e do Processo de Convergência às Normas Internacionais ................................................64 


\section{LISTA DE QUADROS}

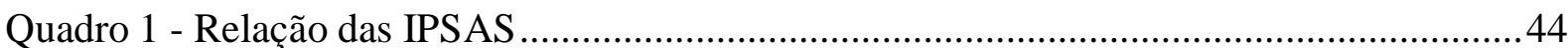

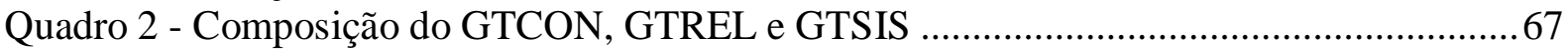

Quadro 3 - Ações de Capacitação realizados desde 2010 e atores envolvidos ........................76

Quadro 4 - Ações Realizadas pelos principais Atores no Processo de Convergência às Normas

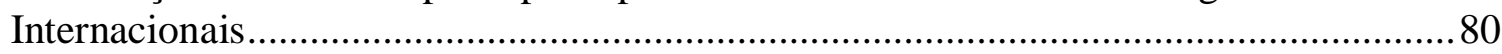




\section{LISTA DE TABELAS}

Tabela 1 - Grau de Percepção acerca do Processo de Convergência da Contabilidade Pública

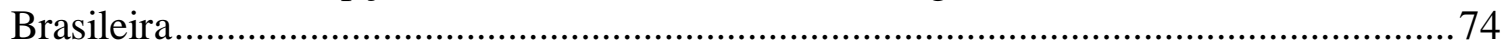

Tabela 2 - Influência dos Atores no Processo de Convergência Brasileiro.............................. 79 


\section{LISTA DE ABREVIATURAS E SIGLAS}

ABM Associação Brasileira de Municípios

AIC Associação Interamericana de Contabilidade

ABRACOM Associação Brasileira dos Tribunais de Contas dos Municípios

ATRICON Associação dos Membros dos Tribunais de Contas do Brasil

BACEN Banco Central do Brasil

BB Banco do Brasil

BID Banco Interamericano de Desenvolvimento

BM Banco Mundial

BSPN Balanço do Setor Público Nacional

CCONF Coordenação-Geral de Contabilidade

CCONT Coordenação-Geral de Normas de Contabilidade Aplicadas à Federação

CF/88 Constituição Federal de 1988

CFC Conselho Federal de Contabilidade

CGF Conselho de Gestão Fiscal

CGU Controladoria-Geral da União

CONACI Conselho Nacional de Controle Interno

CVM Comissão de Valores Mobiliários

DCASP Demonstrações Contábeis Aplicadas ao Setor Público

DF Distrito Federal

EFS Entidades de Fiscalização Superiores

EPSAS European Public Sector Accounting Standards

ESAF Escola de Administração Fazendária

e-SIC Sistema Eletrônico do Serviço de Informação ao Cidadão

FASAB Federal Accounting Standards Board Advisory

FGV Fundação Getúlio Vargas

FMI Fundo Monetário Internacional

GASB Governmental Accounting Standards Board

GFIN Grupo de Finanças Estaduais

GTCON Grupo Técnico de Padronização de Procedimentos Contábeis

GTREL Grupo Técnico de Padronização de Relatórios

GTSIS Grupo Técnico de Sistematização de Informações Contábeis e Fiscais

IBRACON Instituto dos Auditores Independentes do Brasil

IFAC International Federation of Accountants

IIA Institute of Internal Auditors

INTOSAI International Organisation of Supreme Audit Institutions

IPSAS International Public Sector Accounting Standards

IRB Instituto Rui Barborsa

LRF Lei de Responsabilidade Fiscal - LC 101/2000

MCASP Manual de Contabilidade Aplicada ao Setor Público

MDF Manual de Demonstrativos Fiscais

NAO National Audit Office

NBCASP Normas Brasileiras de Contabilidade Aplicada ao Setor Público

OCDE Organização para a Cooperação e Desenvolvimento Económico

PCASP Plano de Contas Aplicado ao Setor Público

PIB Produto Interno Bruto 
RCPGs Relatórios Contábeis de Propósito Geral das Entidades do Setor Público RM Ranking Médio

SCF Sistema de Contabilidade Federal

SIAFI Sistema Integrado de Administração Financeira do Governo Federal

STN Secretaria do Tesouro Nacional

TCE Tribunal de Contas dos Estados

TCM Tribunal de Contas dos Municípios do Estado

TCs Tribunais de Contas no nível subnacional

TCU Tribunal de Contas da União

UNDP United Nations Development Programme 


\section{SUMÁRIO}

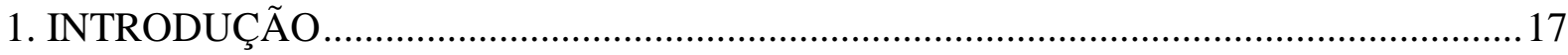

1.1 CONTEXTUALIZAÇÃO DO PROBLEMA DA PESQUISA ……………………….....17

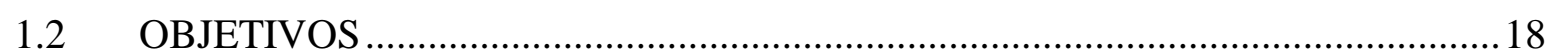

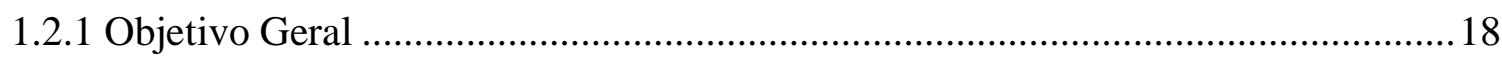

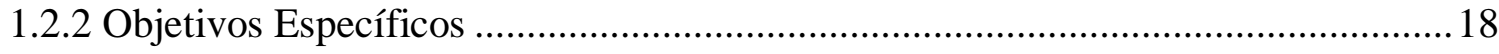

1.3 JUSTIFICATIVA E PRESSUPOSTO ………………………………………......19

1.4 DELIMITAÇÃO DA PESQUISA...................................................................... 20

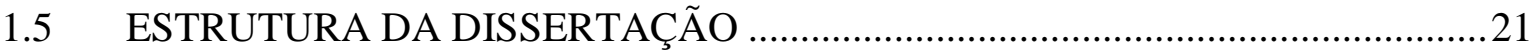

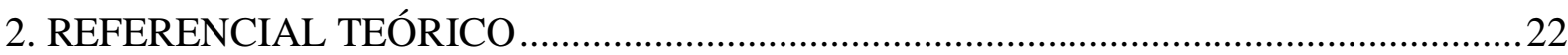

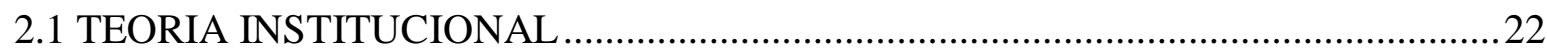

2.2 O PROCESSO DE REFORMA DA CONTABILIDADE PÚBLICA E MODELOS

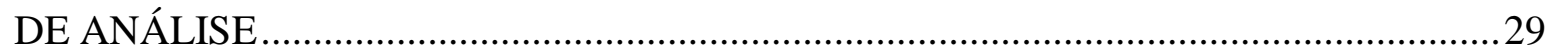

2.3 DISPOSIÇÃO INSTITUCIONAL DO ESTADO BRASILEIRO ............................39

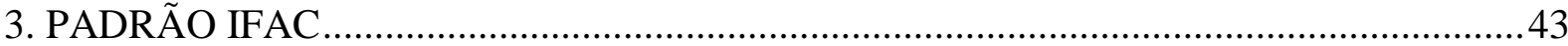

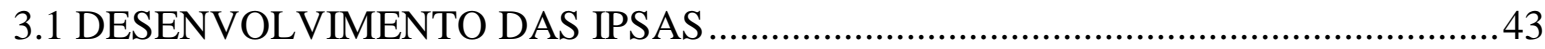

3.2 EXPERIÊNCIAS INTERNACIONAIS NA ADOÇÃO DAS IPSAS ............................47

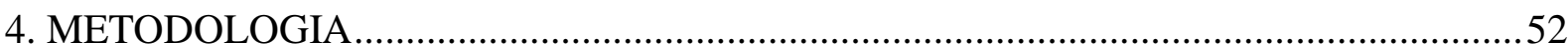

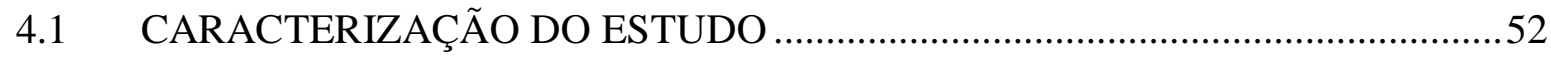

4.2 COLETA E TRATAMENTO DOS DADOS ......................................................53

5. A INFLUÊNCIA DOS ATORES NO PROCESSO DE CONVERGÊNCIA DA CONTABILIDADE PÚBLICA NO BRASIL ......................................................................57

5.1 PANORAMA DO PROCESSO DE CONVERGÊNCIA BRASILEIRO .................57

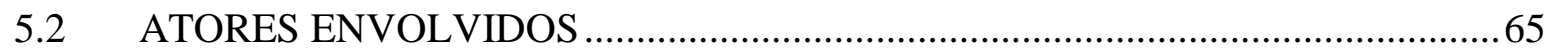

5.3 A TRAJETÓRIA DOS PRINCIPAIS ATORES E A PROMOÇÃO E DIRECIONAMENTO DO PROCESSO DE CONVERGÊNCIA ……...................................68

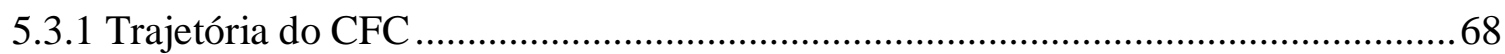

5.3.2 Trajetória da STN …………………………………………………………..... 70

5.3.3 Trajetória do TCU ...........................................................................................

5.3.4 Promoção e Direcionamento do Processo de Convergência ……………………......72

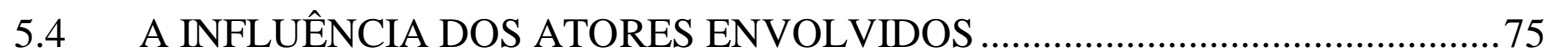

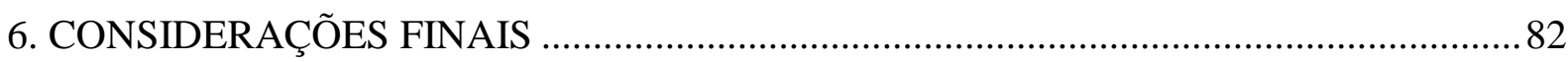

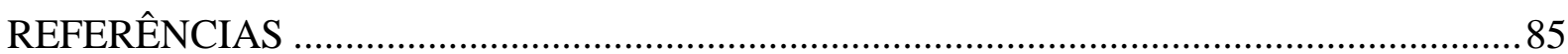


APÊNDICE A - Roteiro Semiestruturado para Entrevistas ...............................................96

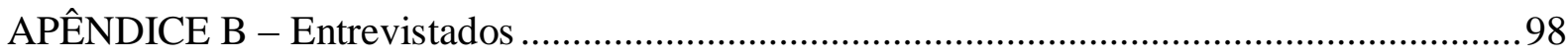

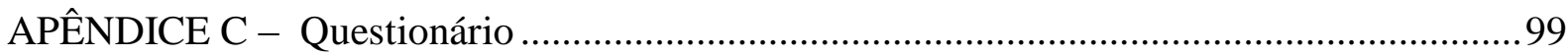

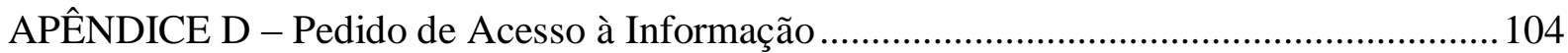

ANEXO A - Adoção das IPSAS: Resumo das Jurisdições que já Adotaram ou estão em

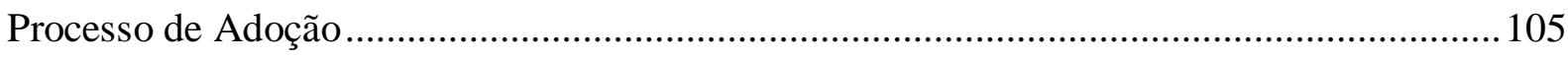

ANEXO B - Portarias CFC relacionadas à Grupos na área de Contabilidade Pública.......... 111

ANEXO C - Histórico de Portarias que fixaram prazos de observância obrigatória dos procedimentos contábeis contidos no MCASP ................................................................. 114

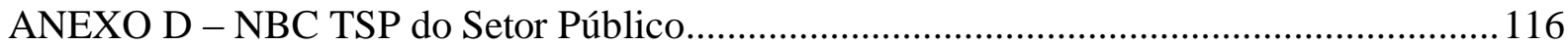




\section{INTRODUÇÃO}

\subsection{CONTEXTUALIZAÇÃO DO PROBLEMA DA PESQUISA}

A literatura apresenta que desde os anos de 1980 a contabilidade governamental vem sofrendo mudanças fundamentais em inúmeros países, sendo que as primeiras orientações internacionais para uma reforma começaram a partir do ano de 2001, quando os pronunciamentos começaram a ser promulgados (LÜDER, 2009). Segundo Nobes e Parker (2008), a pressão para a harmonização internacional vem ocorrendo por parte tanto daqueles que regulam como dos que preparam e utilizam as demonstrações financeiras.

$\mathrm{Na}$ visão de Benito, Brusca e Montesinos (2007), o grau de padronização da contabilidade no setor público é menor do que no setor privado, sendo o interesse na harmonização também menor ou em alguns casos até mesmo inexistente. Entretanto, os autores apontam como razões em favor desse processo de harmonização a externalização da atividade financeira da administração pública, o auxílio na preparação e comparação da contabilidade, e a ajuda na modernização generalizada dos sistemas contábeis nos países menos desenvolvidos.

Para Chan (2010), a reforma da contabilidade governamental é considerada parte da melhoria da gestão pública, com a expectativa que contribua para o desempenho do governo. Nascimento (2007) entende que há cada vez mais a necessidade de confrontação entre as finanças públicas de diversas nações, para que existam parâmetros que permitam verificar o desempenho de cada uma delas.

Diante desse cenário, a Internacional Federation of Accountants - IFAC criou, no ano 2000, o Comitê do Setor Público, que passou a emitir as primeiras Normas Internacionais de Contabilidade do Setor Público ou International Public Sector Accounting Standards (IPSAS, em inglês) (CRUVINEL; LIMA, 2011). A emissão das IPSAS pode ser considerada um importante estímulo para a harmonização da contabilidade do setor público (BENITO; BRUSCA; MONTESINOS, 2007).

No Brasil, o processo de convergência da contabilidade pública às IPSAS vem sendo discutido na academia sob uma perspectiva operacional, quase sempre mostrando os impactos que a aplicação dos novos procedimentos contábeis pode trazer sobre as contas públicas (CARVALHO; COSTA; OLIVEIRA, 2010; SILVA et al., 2012; VIANA et al. 2013; SILVA et al., 2014). 
$\mathrm{Na}$ literatura internacional, estudos também têm sido realizados para analisar como os fatores culturais, a interferência política, o nepotismo e o excesso de burocracia (GODDARD et al., 2015) afetam o processo de convergência aos padrões contábeis internacionais. Em que pese essas informações serem relevantes para compreender como a harmonização contábil vem sendo instituída, ainda são escassos os estudos que mostram como os atores influenciam o processo de mudança nos diferentes países.

\subsection{OBJETIVOS}

\subsubsection{Objetivo Geral}

Considerando que na perspectiva da análise institucional a mudança nos padrões contábeis mobiliza vários recursos organizacionais de natureza institucional (BORGES, 2012), que são escassos os trabalhos empíricos no que diz respeito à implementação das IPSAS e que estas pesquisas não têm como foco os países latino-americanos ou não apresentam informações acerca de iniciativas recentes (BRUSCA; GÓMEZ-VILLEGAS; MONTESINOS, 2016), a questão problema do presente estudo está delimitada da seguinte forma: como os atores vêm influenciando no processo de convergência da contabilidade pública brasileira aos padrões contábeis internacionais?

Assim, o objetivo geral deste trabalho é analisar a influência dos atores no processo de convergência da contabilidade pública brasileira aos padrões internacionais.

\subsubsection{Objetivos Específicos}

Para atingir o objetivo geral foram estabelecidos os seguintes objetivos específicos:

i. Compreender o processo de reforma da contabilidade pública e apresentar os modelos de análise discutidos na literatura;

ii. Apresentar o cenário do Governo brasileiro, identificando a sua disposição institucional e descrever brevemente aspectos da contabilidade pública no País;

iii. Apresentar o Padrão IFAC e as IPSAS como referência internacional para o desenvolvimento de sistemas de contabilidade;

iv. Levantar experiências internacionais no processo de adoção das IPSAS;

v. Fornecer o panorama do processo de convergência da contabilidade pública brasileira aos padrões internacionais, com o desenvolvimento de uma linha temporal dos principais normativos relacionados ao mesmo; 
vi. Identificar os principais atores envolvidos no processo de convergência da contabilidade publica brasileira aos padrões internacionais.

\subsection{JUSTIFICATIVA E PRESSUPOSTO}

Alguns estudos trazem que as normas e políticas contábeis são produtos sociais e, dessa forma, sofrem influência do ambiente institucional (BELKAOUI, 1983; HOPWOOD, 1994). Assim, a contabilidade, como um sistema aberto, é influenciada por diversos fatores, de maneira que a decisão de adotar ou não um padrão internacional está relacionada com o ambiente institucional do país, especialmente o seu sistema legal e características macroeconômicas (NOBES; PARKER, 2008; RADEBAUGH; GRAY; BLACK, 2006; MAPURUNGA; MENESES; PETER, 2011).

Oulasvirta (2014) justifica a utilização da teoria institucional em contabilidade pública por ser uma perspectiva viável para explicar as múltiplas pressões institucionais sobre escolhas contábeis mediante a análise de interação da influência normativa, coercitiva e isomorfismo mimético com outras jurisdições. Segundo o pesquisador, como a abordagem institucional afirma que as organizações estão sujeitas a influências sociais e pressões para a adoção de práticas consideradas adequadas, revela-se coerente para o objetivo da pesquisa. $\mathrm{O}$ autor revela ainda que um ponto forte da análise institucional é que:

[...] ela vê culturas e regimes contábeis, como sistemas abertos com interfaces permeáveis e podem, assim, ser bem aplicada à interação das normas internacionais e as normas nacionais de contabilidade. As normas internacionais têm uma influência sobre regimes e práticas de contabilidade do Setor Público nacionais, mesmo se essas normas não são totalmente e formalmente aceitos em um país. As tradições e regimes, nacionais e locais, de contabilidade estão desenvolvendo na interseção de diferentes forças ligadas ao isomorfismo institucional. (Oulasvirta, 2014, p. 283)

Nesse sentido, a teoria institucional oferece possibilidade para compreender essas mudanças, especialmente relacionadas a regulação contábil, padrões de contabilidade internacional e decisões acerca da adoção de normas internacionais (SOEIRO, 2015). Além disso, os processos de mudança na contabilidade podem ser entendidos como resultado complexo e combinado dos processos de institucionalização, desinstitucionalização e reinstitucionalização (DJELIC; QUACK, 2008).

Entretanto, o enfoque no setor público, a partir dessa teoria, pode ser considerado recente, com destaque para estudos acerca das forças e pressões externas capazes de ocasionar mudanças na contabilidade local, sendo o isomorfismo a principal explicação nas pesquisas que tratam sobre os fatores que influenciam a contabilidade de outros países (SOEIRO, 2015). 
Da perspectiva do isomorfismo, as organizações sofrem influências e pressões sociais para adotar práticas que são consideradas adequadas.

Ademais, pesquisadores como Adhikari e Gårseth-Nesbakk (2016) alertam que falta na literatura do setor público explorar as vozes dos atores a nível organizacional, especialmente de contadores do governo e decisores políticos, envolvidos na implementação da contabilidade. Até porque, segundo os autores, a forma e a profundidade do envolvimento de atores fazem com que organizações respondam de forma diferente para reformas semelhantes.

Desta forma, este estudo trará como pressuposto o conceito de influência defendido por Robert Dahl (1958, p. 203), onde "A tem poder sobre B, na medida em que ele pode levar B a fazer algo que, de outra forma, não faria".

A expectativa é que o presente estudo contribua para uma melhor compreensão, e até mesmo documentação, do processo de convergência das normas de contabilidade pública brasileira aos padrões internacionais. E, especificamente, para a identificação dos atores envolvidos, das ações realizadas e dos que mais tem influenciado no processo. Além disto, cabe acrescentar que a apresentação da experiência brasileira pode ser útil para que países com características institucionais semelhantes aperfeiçoem seus respectivos processos de convergência.

\subsection{DELIMITAÇÃO DA PESQUISA}

A pesquisa terá como suporte teórico a Teoria Institucional, especialmente da perspectiva neoinstitucional, e realizará estudo junto ao governo brasileiro, que se encontra em processo de convergência às IPSAS. A escolha pela IPSAS se deu em razão de essas normas serem a primeira orientação internacional para as reformas na contabilidade do setor público (LÜDER, 2009), e o fato de as mesmas se tornarem uma referência internacional para o desenvolvimento da contabilidade pública (CHRISTIAENS et al., 2015).

A adoção das IPSAS também é vista na literatura como ponto inicial crucial nas mudanças da contabilidade do setor público (GOMES; FERNANDES; CARVALHO, 2015). A escolha do Brasil foi motivada pelo fato de as IPSAS destinarem-se especialmente para os países em desenvolvimento, já que grande parte dos países desenvolvidos possuem normas de contabilidade pública parecidas ou mais rigorosas (CHAN, 2010). 
Registre-se também que a identificação dos atores se deu inicialmente a partir dos achados da literatura e dos normativos emitidos no âmbito do governo brasileiro, e, posteriormente, da percepção dos atores entrevistados.

\subsection{ESTRUTURA DA DISSERTAÇÃO}

Além desta Introdução, esta dissertação está estruturada em mais cinco Seções. Na Seção 2, aborda-se a teoria institucional, seus enfoques e destaca-se a sua utilização no campo contábil, especialmente na área pública. Também, nessa Seção, apresentam-se os aspectos gerais relacionados à necessidade de reforma da contabilidade pública e como esse processo de reforma tem sido conduzido, juntamente com possíveis abordagens para tratar mudanças contábeis no setor público que subsidiam a escolha de variáveis de análise desta pesquisa. Descreve-se, ainda, a disposição institucional brasileira, abordando a estrutura do Estado e a estrutura administrativa, o sistema legal, a qualificação do corpo funcional e aspectos relacionados à cultura, tendo em vista que são variáveis que influenciam as reformas contábeis.

Na Seção 3, apresenta-se o Padrão IFAC, detalhando como as IPSAS são emitidas e as experiências internacionais na adoção dessas normas, buscando apresentar estímulos, características institucionais e a atuação dos atores que influenciaram na condução do processo de reforma nos diversos países.

Os aspectos metodológicos empregados na pesquisa são apresentados na Seção 4, mostrando as classificações da pesquisa e descrevendo a coleta e tratamento dos dados.

$\mathrm{Na}$ Seção 5, é fornecido um panorama do processo de convergência às normas internacionais, desenvolvendo uma linha temporal dos principais normativos da contabilidade pública brasileira, com a identificação dos principais atores envolvidos nesse processo e sua trajetória. Posteriormente, é analisada a influência dos atores envolvidos no processo de convergência da contabilidade pública no Brasil.

Por fim, na Seção 6, são apresentadas as considerações finais e sugestões de pesquisas futuras, seguidas das referências utilizadas. 


\section{REFERENCIAL TEÓRICO}

Nesta Seção, aborda-se a teoria institucional e sua utilização na área contábil, apontando a perspectiva adotada neste estudo. Além disso, discorre-se acerca do processo de reforma da contabilidade pública, diferenciando termos relacionados à convergência contábil e, por fim, apresenta-se modelos que podem ser utilizados para compreensão de mudanças contábeis. Descreve-se, ainda, a disposição institucional brasileira, abordando a estrutura do Estado e a estrutura administrativa, o sistema legal, a qualificação do corpo funcional e aspectos relacionados à cultura, tendo em vista que são variáveis que influenciam as reformas contábeis.

\subsection{TEORIA INSTITUCIONAL}

A teoria institucional pode ser abarcada por diversas perspectivas, sendo, assim, objeto de estudo por diferentes áreas da ciência. Conforme apontam Machado-da-Silva e Gonçalves (1999), essa teoria sofre influências de corpos teóricos oriundos principalmente da ciência política, da ciência econômica e da sociologia.

Selznick (1971, p. 5), considerado um dos precursores no estudo de instituições, faz uma importante distinção no que se refere à instituição e à organização, e define essa última como sendo "[...] um instrumento técnico para a mobilização das energias humanas, visando uma finalidade já estabelecida [...]”. Assim, enquanto a instituição é adaptável, como produto de pressões e necessidades sociais, a organização é um sistema formal de regras e objetivos. Dessa maneira, a institucionalização consistiria em uma "infusão de valores" por parte das organizações, quando elas "[...] passam a simbolizar as aspirações da comunidade, o seu senso de identidade" (SELZNICK, 1971, p. 17). Segundo o autor:

Organizações transformam-se em instituições ao serem infundidas de valor, isto é, avaliadas não como simples instrumentos, mas como fontes de gratificação pessoal direta e veículos de integridade de um grupo. Esta infusão produz uma identidade distinta para a organização (SELZNICK, 1971, p. 34).

De acordo com Burns e Scapens (2000), a teoria institucional pode ser compreendida através de diferentes enfoques: Velha Economia Institucional (OIE - Old Institutional Economics), Nova Economia Institucional (NIE - New Institutional Economics) e Nova Sociologia Institucional (NIS - New Institutional Sociology). 
De forma geral, segundo a ótica OIE, a instituição passa a ser o principal objeto de análise em detrimento do comportamento racional e maximizador dos indivíduos, conforme aceito pela teoria neoclássica. Nesse enfoque, a instituição pode ser entendida como "uma forma de pensamento ou ação de algo prevalecente e permanente, a qual está incorporada nos hábitos de um grupo ou nos costumes de um povo" (HAMILTON, 1932, p. 84). Salienta-se, particularmente na velha economia institucional, a importância do poder e política, aprendizagem e inovação para moldar processos ao longo do tempo (MOLL; BURNS; MAJOR, 2006).

Por outro lado, na NIE busca-se explicar a existência e o surgimento de algumas instituições e a inexistência ou o desaparecimento de outras. Há um abandono do pressuposto neoclássico da maximização da utilidade pelos indivíduos, mas não há um rompimento completo com a teoria econômica neoclássica. Na abordagem da NIE, as instituições existem essencialmente enquanto seus benefícios excederem os custos envolvidos na sua criação e manutenção (MOLL; BURNS; MAJOR, 2006). North (1990, p. 3) afirma que "instituições são as regras do jogo em uma sociedade, ou mais formalmente, são os constrangimentos que moldam a interação humana concebida pelos seres humanos”.

Já na perspectiva da NIS, há uma suposição de que estruturas e procedimentos intraorganizacionais, aí inclusa a contabilidade, são influenciadas em grande parte por fatores externos, em vez de meramente objetivos relacionados à minimização de custos (MOLL; BURNS; MAJOR, 2006).

Na visão de Scott (2001), embora as ideias dos pesquisadores econômicos, políticos e sociológicos possam ser combinadas no intuito de se obter um único, complexo e integrado modelo de uma instituição, é mais útil reconhecer os diferentes pressupostos e ênfase que acompanham os modelos que atualmente orientam a investigação para estes fenômenos.

Entretanto, essas ideias possuem em comum o interesse nas instituições e nas mudanças institucionais (GUERREIRO et al., 2005). Segundo Peci (2006), ambos, o velho e o novo institucionalismo, apresentam ceticismo perante o pressuposto de ator racional, e, assim, nas análises, passa-se a focar na relação das organizações com o seu ambiente, ampliando, contudo, os limites desse ambiente. Conforme aponta Peci (2006), talvez a maior diferença entre essas escolas consista na influência do construtivismo social, que é adotado como perspectiva oficial no novo institucionalismo, e que a visão de realidade como socialmente construída é um ponto comum entre os principais proponentes neoinstitucionalistas. 
No início do neoinstitucionalismo, os pesquisadores tendiam a enfatizar as maneiras pelas quais os mecanismos institucionais limitavam as estruturas e atividades organizacionais, passando, posteriormente, a dar atenção também na forma como os indivíduos e as organizações inovam, agem estrategicamente e contribuem para a mudança institucional (SCOTT, 2001).

Scott (2001) aponta como um diferencial dessa teoria o reconhecimento de que as organizações estão imersas em um ambiente institucional e técnico, e a disponibilidade de recursos não é suficiente para a sobrevivência das organizações, já que também é necessária a legitimidade social. Machado-da-Silva e Fonseca (1996) também buscaram entender essa relação:

Ambientes técnicos, ou espaços de competência na ótica econômica, da troca
de bens ou serviços, de modo que as organizações que nele se incluem são
avaliadas pelo processamento tecnicamente eficiente do trabalho [...]. Os
ambientes institucionais caracterizam-se, por sua vez, pela elaboração e
difusão de regras e procedimentos, que proporcionam às organizações
legitimidade e suporte contextual (MACHADO-DA-SILVA; FONSECA,
1996, p. 103-104)

Segundo Zucker (1987, p. 445), a “[...] conformidade organizacional com o ambiente institucional simultaneamente aumenta a avaliação positiva, o fluxo de recursos e, portanto, as chances de sobrevivência, e reduz a eficiência”. Vale destacar que essa necessidade de aceitação social e credibilidade, necessárias para a sobrevivência as organizações, estão relacionadas com o conceito de legitimidade. Para Suchman (1995), legitimidade é "uma percepção generalizada ou suposição de que as ações de uma entidade são desejáveis, adequadas ou apropriadas dentro de um sistema construído de normas, valores, crenças e definições.".

Assim, sob a ótica da NIS, as instituições são compostas por três pilares: regulador, normativo e cultural-cognitivo, que conferem estabilidade e significado ao comportamento social, de maneira que para uma organização ser socialmente legítima, ela deve adotá-los (SCOTT, 2001). Cada pilar fornece uma base para a legitimidade, ainda que de forma distinta, conforme Figura 1. 
Figura 1- Pilares institucionais e variação de níveis: escolas ilustrativas

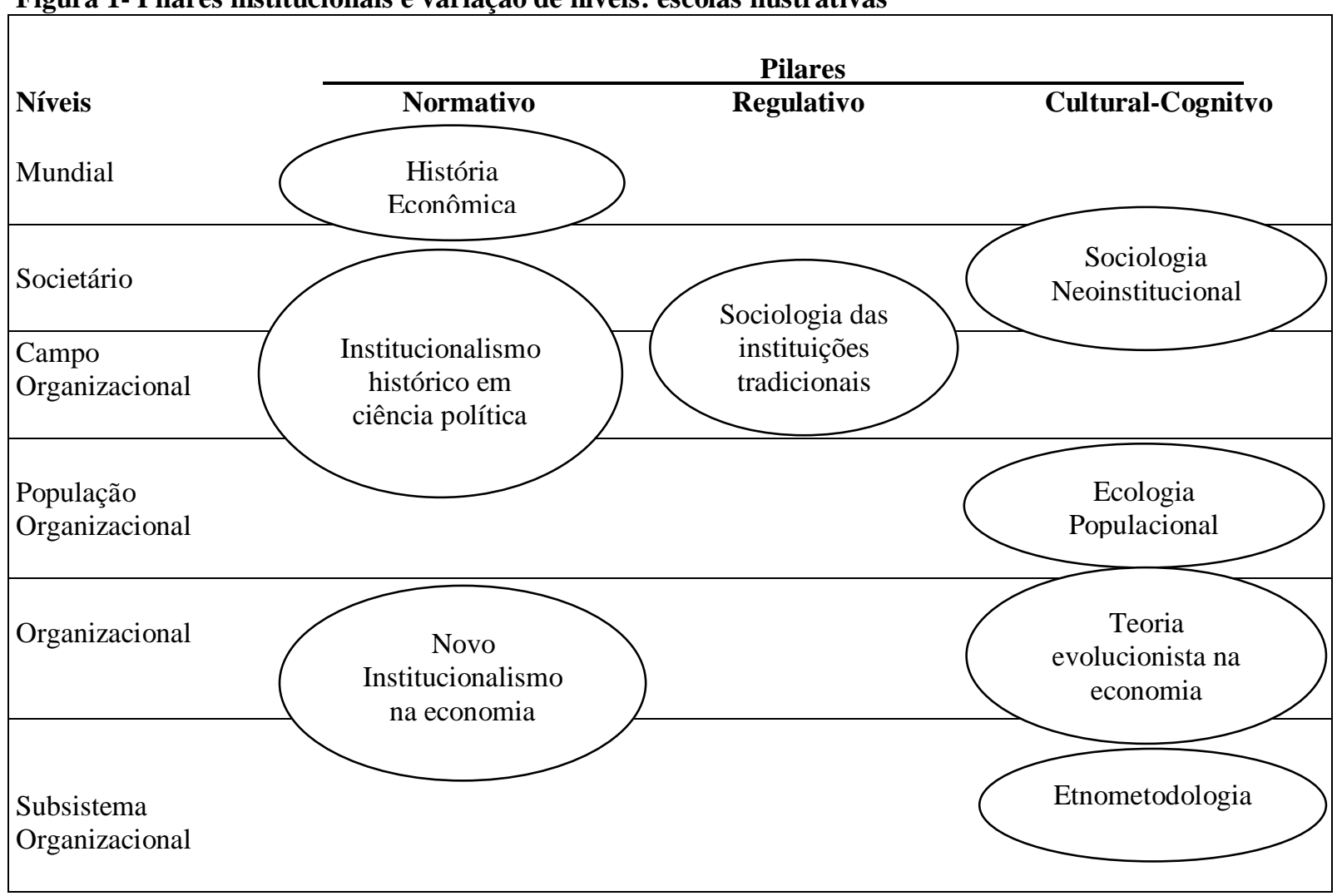

Fonte: Adaptado (tradução nossa) de Scott (2001, p. 87).

Conforme conceitua Scott (2001), a estrutura reguladora está relacionada aos processos sociais, pelos quais regras de comportamento, que orientam condutas, são estabelecidas. As regras são definidas por meio de sanções, que podem ser estabelecidas na forma de recompensas ou punições. Para o pesquisador, esta dimensão das instituições pressupõe racionalidade nas decisões dos atores, assim como a busca do interesse próprio, de maneira que os efeitos das instituições sobre o comportamento social ocorrem através de influência na consideração do custo-benefício dos indivíduos, grupos e organizações.

A estrutura normativa das instituições revela que há "regras que introduzem uma dimensão relacionada a prescrições, avaliações e obrigações na vida social”, e estas são materializadas em normas e valores. A presente estrutura se difere da anterior na questão da racionalidade instrumental, uma vez que nesta estrutura os atores possuem a tendência de agirem de acordo com o que é esperado deles, baseando-se no que é socialmente adequado para a situação (SCOTT, 2001).

O pilar cultural-cognitivo consiste nos "conceitos compartilhados que constituem [para os atores] a natureza da realidade e as estruturas através das quais os significados são produzidos" (SCOTT, 2001, p. 57-61). O pesquisador esclarece que tal nível é o mais "profundo", por basear-se em entendimentos dados como certo (taken-for-granted) e salienta 
o papel central desempenhado pela construção socialmente mediada de um quadro comum de significado (SCOTT, 2001). Assim, tais pilares embasam a concepção de instituição apresentada por Scott:

Instituições são compostas de elementos culturais-cognitivos, normativos e regulativos que juntamente com atividades e recursos associados proporcionam estabilidade e sentido ao comportamento social (SCOTT, 2001, p. 48).

Machado-da-Silva, Fonseca e Crubellate (2005) ressaltam a questão da legitimidade. Esta é tratada como elemento chave da teoria neoinstitucional, ao permitir a manutenção ou mudança das instituições, assim como indagações acerca de adequação das práticas, normas e procedimentos.

Weber (1968) foi um dos primeiros teóricos sociais a chamar atenção para importância central da legitimidade na vida social. O conceito de legitimidade enfatiza a consistência dos objetivos organizacionais com as funções sociais (SCOTT, 2001). Nesse sentindo, Meyer e Rowan (1977) afirmam que:

Assim, o sucesso organizacional depende de fatores que vão além da eficiência na coordenação e controle das atividades de produção. Independentemente de sua eficiência produtiva, organizações inseridas em ambientes institucionais altamente elaborados legitimam-se e ganham os recursos necessários para a sua sobrevivência se conseguirem tornar-se isomórficas nos ambientes (MEYER; ROWAN, 1977, p. 352).

Ainda sob a perspectiva da legitimidade, Meyer e Rowan (1977, p. 341) definem o processo de institucionalização como "[...] os modos pelos quais processos sociais, obrigações ou atualidades passam a ter um status de regra no pensamento e na ação social".

Powell e DiMaggio (1983) tratam a institucionalização como resultante do processo de homogeneização dos campos organizacionais, que ocorre por meio de mecanismos isomórficos. Na visão dos pesquisadores, o isomorfismo pode ser entendido como a tendência das organizações em áreas similares em adotar formas e procedimentos similares no intuito de obter legitimidade.

O princípio do isomorfismo foi aplicado a organizações primeiro pelo ecologista Amos Hawley (1968). Posteriormente, DiMaggio e Powell (1983, p. 147) reforçaram a ênfase no isomorfismo institucional, apontando que ele "faz as organizações mais similares sem necessariamente torná-las mais eficientes”. Assim, os autores distinguem dois tipos de isomorfismo: o competitivo e o institucional, objeto do presente estudo, sendo que esse último pode ser segregado em coercitivo, mimético e normativo. 
O isomorfismo coercitivo resulta de pressões formais e informais realizadas por outras organizações ou pela sociedade. A regulamentação governamental pode ser apontada como uma forte fonte coercitiva. No caso do isomorfismo mimético, as mudanças estão relacionadas à incerteza e ocorrem por meio da adoção de procedimentos implantados com êxito por outras organizações. $O$ isomorfismo normativo, por sua vez, decorre da profissionalização, conduzindo a formas semelhantes de interpretação e atuação diante de demandas e problemas organizacionais (DIMAGGIO; POWELL, 1983).

Para Scott (2001) as mudanças institucionais podem ocorrer de duas formas: a natural e via ação de agentes de mudança ou empreendedores institucionais. Enquanto a primeira decorre de adaptações espontâneas ao ambiente em que a instituição está inserida, emergindo de ações coletivas, a segunda envolve uma intenção por parte dos agentes em modificar as instituições vigentes, ou criar novas instituições. Assim, os empreendedores institucionais podem ser compreendidos como "atores com interesses em arranjos institucionais específicos e que mobilizam recursos para criar novas instituições ou transformar as existentes" (BATTILANA, 2006, p. 654). Nesse contexto de mudança institucional, deve-se observar também a institucionalização do campo organizacional, já que quanto mais institucionalizado mais difícil é para realizar mudanças (DIMAGGIO; POWELL, 1983).

Ademais, Baratter, Ferreira e Costa (2010) ressaltam que a influência exercida pelos atores nas instituições tem sido um tema não muito abordado. E Argento e Van Helden (2010, p. 793) destacam a importância da participação dos atores envolvidos no processo de reforma, nas suas diversas etapas, já que a coesão e colaboração desses demonstram ser fatores determinantes para atingimento dos objetivos esperados.

Ressalta-se que para Potter (2005) a contabilidade, como prática social e institucional, é capaz de influenciar indivíduos, organizações e a sociedade como um todo. No entanto, da mesma forma que influencia o ambiente, a contabilidade molda-se pelo seu contexto institucional, tanto no que se refere à sua forma quanto à sua função (MOLL; BURNS; MAJOR, 2006). Assim, as práticas contábeis podem ser vistas como uma instituição, de forma que a institucionalização seria compreendida como um processo social, de caráter durável e dinâmico, tendo em vista que são continuamente reconstruídas por atores sociais (GUARIDO FILHO; COSTA, 2012).

Soeiro (2015, p. 48) revela que a escolha pelo isomorfismo de DiMaggio e Powell (1983) parece ser a principal escolha entre os pesquisadores ao tratar sobre pressões e forças externas que influenciam a contabilidade das organizações ou dos países (OULASVIRTA, 2014; ALBU; ALBU; ALEXANDER, 2014; HASSAN; RANKIN; LU, 2014). Dessa forma, a 
teoria institucional tem sido bastante utilizada nos estudos que buscam uma compreensão do porquê e como a contabilidade se torna o que é (MOLL; BURNS; MAJOR, 2006).

Não obstante a teoria institucional ser utilizada principalmente em pesquisas gerenciais, ela também pode ser aplicada em outras áreas da contabilidade como a societária, a ambiental e social. Ela tem sido útil para compreender a regulação contábil, os padrões de contabilidade internacional, assim como as decisões acerca da adoção de normas internacionais (SOEIRO, 2015).

Cieslewicz (2014) fornece evidências de que internacionalmente as diferenças contábeis estão relacionadas às diferenças culturais e institucionais, indicando que a contabilidade em uma determinada nação está ligada a instituições de apoio da nação, e essas instituições, por sua vez, são influenciadas pela cultura econômica nacional daqueles que as mantêm. Tal resultado é relevante por implicar que as mudanças contábeis, no caso a convergência, dentro de uma nação, envolve não apenas a aprovação formal das normas, sendo necessários ajustamentos institucionais.

Na literatura já há estudos também analisando a contabilidade pública sob a teoria institucional (EZZAMEL et al., 2007; OULASVIRTA, 2014; HYNDMAN et al., 2014), ora abordando as forças externas e configurações de padrões no setor público (AHN, et al., 2014; OULASVIRTA, 2014) ora estudando a evolução de sistemas contábeis e a mudança no referido setor (COVALESKI; DIRSMITH; WEISS, 2013; VAN HENGEL; BUDDING; GROOT, 2014).

No entanto, Goddard et al. (2015) apontam a falta de estudos comparando a implementação de reforma em diferentes configurações do setor público de países em desenvolvimento utilizando tal teoria. Para os autores, os conceitos da teoria institucional, de legitimidade e de isomorfismo são úteis na compreensão de práticas contábeis no setor público nesses países.

Ressalta-se que quando há introdução de procedimentos contábeis compatíveis com as regras, rotinas e padrões de pensar e fazer já existentes no âmbito da organização, a mudança se mostra menos problemática (BURNS; SCAPENS, 2000). Além disso, em países onde a contabilidade pública pode ser considerada forte, a adoção do padrão internacional sofre uma grande resistência (AHN et al., 2014; OULASVIRTA, 2014). A capacidade técnica, o poder e os velhos hábitos de atores locais influenciam na extensão em que um novo sistema de contabilidade pode ser internalizado (HARUN; KAMASE, 2012).

Nesta pesquisa adota-se a perspectiva sociológica para análise do problema de pesquisa. Neto e Colauto (2010) afirmam que a abordagem sociológica tem chamado a 
atenção dos pesquisadores na área contábil brasileira, apesar de estudos sobre o tema ainda serem incipientes. Para Fachin e Mendonça (2003), a perspectiva sociológica oferecida pela referida teoria pode ser vista como uma das mais robustas na teoria organizacional.

Para o Conselho Federal de Contabilidade (CFC) do Brasil, como órgão regulador dos procedimentos contábeis e membro da IFAC (AMARAL; LIMA, 2013), a institucionalização da contabilidade aplicada ao setor público perpassa todos os níveis de atuação, devendo, dessa forma, ser inserida tanto no modo de vida, como no vocabulário e nas preocupações cotidianas, para um exercício pleno de cidadania (CFC, 2007).

\subsection{O PROCESSO DE REFORMA DA CONTABILIDADE PÚBLICA E MODELOS DE ANÁLISE}

A contabilidade, considerada como linguagem "dos negócios", passou a servir de instrumento de processo decisório em nível internacional, especialmente no cenário atual de mercados globalizados. Entretanto, devido às particularidades de cada país, as práticas adotadas são diferentes. Nesse sentido, a fim de proporcionar a compreensão dessa linguagem e sua comparabilidade, observou-se uma necessidade de buscar critérios contábeis harmônicos, ou seja, a harmonização contábil internacional (NIYAMA, 2009).

O CFC (2007) ratifica esse entendimento ao afirmar que a globalização, a disseminação de empresas multinacionais, a necessidade de alternativas de investimentos para o desenvolvimento dos países emergentes e a expansão dos mercados de capitais com oferta de ações em bolsas de valores internacionais, ensejaram a criação de procedimentos padronizados de contabilidade e auditoria.

Nesse sentido, é importante realizar uma distinção entre normatização (standardization) e harmonização. Enquanto o primeiro parece implicar em um conjunto de regras mais rígidas e restritas, a harmonização é um processo com vistas ao aumento de comparabilidade, definindo limites no seu grau de variação. No entanto, no campo contábil, as palavras tornaram-se quase termos técnicos, e, assim, não se pode contar com as diferenças normais de seus significados (NOBES; PARKER, 2008).

Os pesquisadores comentam que se deve realizar uma diferenciação também quanto à harmonização de regra (de jure) da harmonização de práticas (de facto), pois, segundo Tay e Parker (1990), a harmonização de facto é mais útil do que de jure. E, por fim, há também a questão da uniformidade, onde dois ou mais conjuntos de regras ou práticas são os mesmos. 
Em princípio, pode-se ter harmonia sem ter necessariamente a uniformidade, e vice-versa (NOBES; PARKER, 2008).

Weffort (2005) entende que a harmonização é um processo no qual as diferenças nas práticas contábeis entre os países são reduzidas. De acordo com a pesquisadora, essa redução não deve ser confundida com a eliminação, tendo em vista que os países devem atender às suas especificidades, o que ocasiona, obrigatoriamente, diferenças entre eles.

Para Pohlmann (1995, p. 13), a "harmonização das normas contábeis é um processo necessário e natural" devido ao atual cenário de internacionalização e globalização dos negócios, que traz como provável consequência a necessidade de mais informações de natureza contábil, com conteúdo claro e compreensível.

Zeff (2007) afirma que o termo convergência passou a ser adotado na área contábil no final da década de 1990, inclusive, por organismos de normatização nacional, relacionando o mesmo ao aumento da compatibilidade dos padrões a um alto nível de qualidade. Niyama e Silva $(2009$, p. 16) afirmam que o termo convergência está relacionado à ideia de "movimento em direção a", o que indica um processo para a adoção de uma linguagem comum. A harmonização e convergência internacional podem se tornar uma realidade através da adoção das IPSAS a nível nacional, no entanto, o processo pode demandar uma abordagem incremental (BRUSCA; MARTINEZ, 2015).

De acordo com Sutcliffe (2003), os padrões internacionais de contabilidade pública são ferramentas indispensáveis para o fortalecimento da transparência e governança pública, além de promovem a utilização de boas práticas, que contribui para uma maior consistência dos relatórios financeiros emitidos pelos governos. Ao atender aos padrões contábeis internacionais, as contas apresentadas passam a ter maior credibilidade tanto para os cidadãos quanto para as autoridades públicas e a comunidade internacional de uma maneira geral, incluindo financiadores e agências de rating (CAVANAGH; BENITO, 2015).

Nesse contexto, Mapurunga, Meneses e Peter (2011) destacam que os organismos internacionais que tratam de normatização contábil têm desenvolvido diversas ações no intuito de criar as condições para que ocorra a convergência dos procedimentos contábeis adotados nos diversos países aos aceitos e praticados internacionalmente.

No setor privado, o processo de harmonização teve início em 1973, com a criação do Internacional Accounting Standards Committee - IASC, que tinha como objetivo formular e publicar, de forma independente, um novo padrão de normas contábeis internacionais. Em 2001 foi criado o Internacional Accounting Standards Board - IASB, que assumiu as 
responsabilidades técnicas do IASC. Já no setor público, esse papel foi assumido pela Internacional Federation of Accountants - IFAC (CRUVINEL; LIMA, 2011)

Ribeiro e Bizerra (2011, p. 56) apontam que na área privada a convergência está relacionada à expansão do mercado e à necessidade de uma linguagem contábil comum. No entanto, na área pública este processo pode ser visto como parte de uma reforma mais ampla, conhecida como New Public Management (NPM). Assim, no setor público, na maior parte dos casos, essas reformas fazem parte desse processo mais amplo de modernização da gestão pública em que há uma intenção de restrição e controle das despesas públicas (BENITO; BRUSCA; MONTESINOS, 2007).

Brusca e Martinez (2015) relatam que a profundidade das reformas tem sido variada, e, na maioria dos casos, elas foram realizadas em todos os níveis (nacional, regional e local). Baseado em estudos anteriores, os autores afirmam que nestes processos de reforma, as IPSAS, emitidas pelo IPSASB, têm desempenhado um papel importante.

Gomes, Fernandes e Carvalho (2015) argumentam que apesar de existir um movimento para harmonização das normas de contabilidade pública, pesquisas têm mostrado poucas evidências de eficiência na adoção do sistema de competência no setor público. Entretanto, deve-se ressalvar que quando se fala em convergência às normas internacionais de contabilidade pública, as mudanças abrangem questões mais amplas que a mudança de regime contábil.

Diante desses fatores, a literatura evidencia diferentes possibilidades de abordagem das mudanças contábeis no setor público (LÜDER, 2001; OUDA 2001, 2004; GODDART, 2010; ADHIKARI; GÅRSETH-NESBAKK, 2016), como os Modelos de Contingência, o Financial Management Reform (FMR) e o Modelo de Requisitos Básicos.

Para Revoredo (2008), ao desenvolver o Modelo de Contingência de inovações da contabilidade pública no ano de 1990, Lüder contribuiu para o conhecimento dos fatores que podem ocasionar nas diferenças nos sistemas contábeis governamentais. O modelo, fundamentalmente econômico, identificou inicialmente variáveis contextuais, segregadas em (i) estímulos, (ii) ambiente social do governo, (iii) características do sistema políticoadministrativo e (iv) barreiras de implementação (CHAN; JONES; LÜDER, 1996).

A segunda geração desse modelo de Lüder introduziu a diferenciação do papel dos atores políticos e dos atores administradores, em resumo, passando a considerar que a política também afeta a contabilidade governamental. A utilização em campo do modelo, assim como o aumento da complexidade das relações, gerou a necessidade de adaptações e uma separação mais clara das variáveis contextuais e de comportamento (CHAN; JONES; LÜDER, 1996). 
Assim, a terceira geração do modelo de Lüder incluiu as consequências da inovação no próprio modelo, já que essas podem produzir efeito que afetam outras variáveis (CHAN; JONES; LÜDER, 1996). Os aperfeiçoamentos realizados resultaram no modelo apresentado na figura 2:

Figura 2 - Modelo de Contingência de Lüder

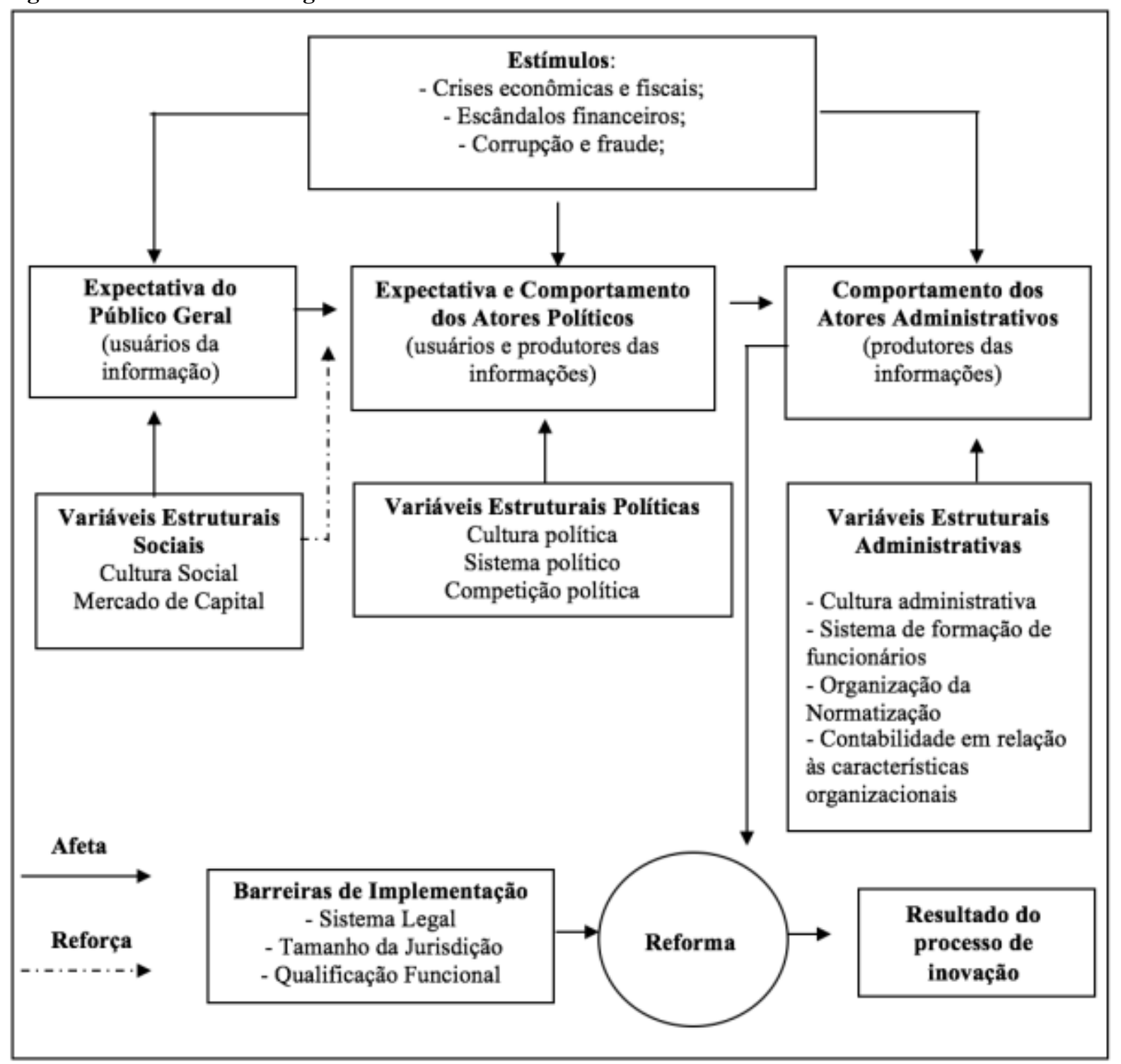

Fonte: Lüder (2001 p. 18), tradução livre.

Diante da adoção de outras modificações sugeridas, bem como experiências e discussões adicionais, Lüder desenvolveu uma revisão completa do modelo, que passou a ser chamado de "Modelo de Processo de Reforma da Gestão Financeira" (Financial Management Reform Process Model ou FMR, em inglês). Dentre as inovações trazidas pelo modelo FMR está a possibilidade de um processo multi-estágio, a partir do estabelecimento de feedback que 
relaciona o comportamento e atitudes de atores chaves no processo com os resultados do processo (LÜDER, 2001).

Registre-se que o FMR agregou variáveis contextuais de estímulo e de disposição institucional; variáveis comportamentais relacionadas aos direcionadores de reforma, aos promotores de reforma e aos stakeholders; e variáveis instrumentais acerca do conceito de reforma e da estratégia de implementação (LÜDER, 2001) (Figura 3).

Figura 3 - Modelo Financial Management Reform (FMR) de Lüder

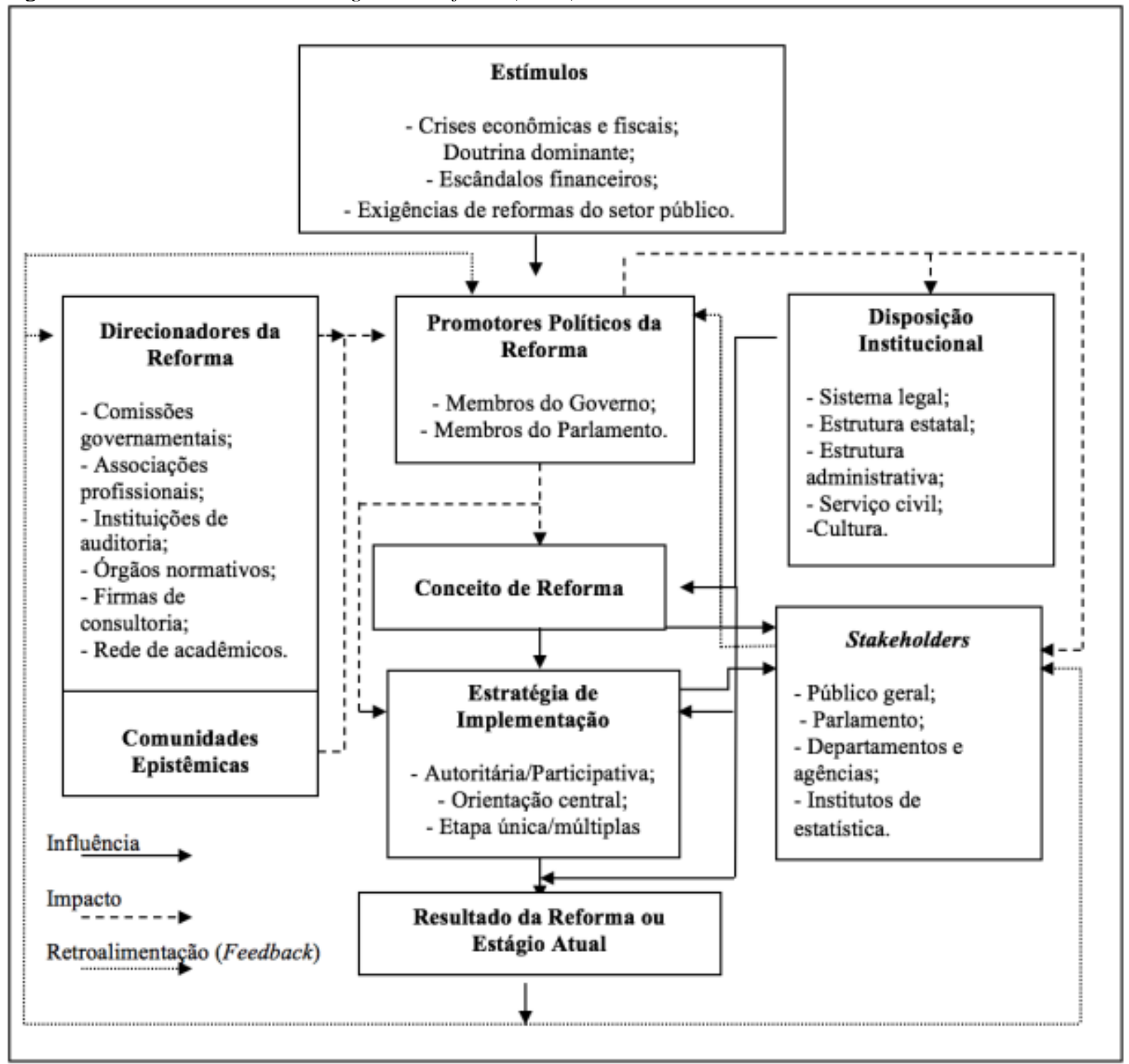

Fonte: Lüder (2001 p. 18), tradução livre.

Dentre as variáveis do modelo detalhadas Lüder (2001) estão o estímulo, os direcionadores e promotores das reformas, a disposição institucional, os stakeholders e a estratégia de implementação, conforme segue:

a. Estímulo: mantém-se basicamente inalterado, apesar da mudança de nomenclatura de 
"pressão fiscal” por "crises econômicas e financeiras", no entanto, geralmente este é fator subjacente da pressão fiscal. "Necessidades derivadas de reformas administrativas" são adicionadas, o que ressalta a realização de reformas contábeis governamentais por motivos relacionadas a reforma administrativas, especialmente em países em desenvolvimento. Lüder passa a considerar também a questão da legitimidade, já que acrescenta o "empreender para melhorar a reputação internacional" como estímulo relevante para as reformas;

b. Direcionadores da reforma: instituições e profissionais reconhecidos, que promovem as reformas através de palestras e publicações voltadas para a reforma da contabilidade pública, visando tornar o assunto uma questão política e influenciar os “fazedores" de decisões políticas. O autor destaca que uma comunidade epistêmica de especialistas pode fortalecer a influência dos direcionadores da reforma;

c. Promotores das reformas políticas: sempre necessários, iniciam a reforma e tem poder para compelir e assegurar tal reforma, normalmente são membros do governo. Para Lüder, o Ministro das Finanças e o Primeiro-Ministro exercem possuem um papel chave no processo de mudança;

d. Disposição institucional: envolve as variáveis consideradas no modelo de contingência, isto é, variáveis estruturais administrativas e políticas, e inclui também as barreiras de implementação. São categorias amplas que, segundo o próprio autor, necessitam de maiores especificações para uma compreensão adequada da disposição institucional de um país;

e. Stakeholders: instituições ou pessoas afetadas positivamente ou negativamente pela reforma, excluídos os promotores políticos e os direcionadores da reforma, do mesmo modo que os institutos de estatística;

f. Estratégia de implementação: a maneira como a reforma vai ser implementada afeta sua probabilidade de sucesso ou de fracasso, bem como os desvios entre o conceito de reforma e o resultado da reforma.

O conceito de reforma não é abordado pelo autor, mas, segundo Revoredo (2008), essa variável pode estar relacionada à motivação da reforma, sua necessidade e relevância, grupos que apresentam resistência e a distância da reforma desejada em relação à realidade governamental.

Já Ouda (2001, 2004), no que tange a análise de reformas no setor público, delimitou sua análise à questão de implementação bem-sucedida do regime de competência na contabilidade pública, diferenciando-se, dessa maneira, do modelo de Lüder, que aborda de 
maneira mais ampla os processos de reforma e de inovação da contabilidade governamental. Ouda (2004) apresenta como justificativa do seu estudo a falta de um quadro referencial de implementação claro que possibilite a criação de um contexto favorável para a introdução bem-sucedida do novo sistema de contábil, tendo em vista que o Modelo de Contingência apenas descreve os fatorem que influenciam a introdução das mudanças e o fato de que a maioria das decisões de reforma são tomadas espontaneamente.

Ouda (2004), baseado em seus estudos acerca das barreiras de implementação do regime de competência no setor de países desenvolvidos e em desenvolvimento, apresenta dez pressupostos acerca dos fatores e mudanças necessários para a criação de condições apropriadas para a introdução e implementação do regime de competência, resultando na Equação 1.

$$
M C(s p)=f(M G+A P B+A P A+C S+V M+C C+O C A+Q C E+C T I)
$$

Onde:

MC $(\mathrm{sp})$ = Mudanças Contábeis (aplicação do regime de competência na contabilidade aplicada ao Setor Público (sp))

$\mathrm{f}=$ Função

MG = Mudanças Gerenciais (mudanças de gestão interna/NPM)

$\mathrm{APB}=$ Apoio Político e Burocrático (apoio legislativo e executivo)

APA = Apoio profissional e Acadêmico (nas áreas de contabilidade e de auditoria)

CS = Estratégia de Comunicação (inclui livretos, revistas, conferências, seminários, etc.)

$\mathrm{VM}=$ Vontade de mudança (motivação do pessoal, vontade e formação e qualificação)

$\mathrm{CC}=$ Consulta e Coordenação (com as entidades governamentais que serão aplicadas o regime de competência contábil).

OCA = Orçamento para os Custos de Adoção (para todo o período de implementação) QCE = Questões Contábeis Específicas (identificação de ativos e avaliação, de ativos registradores, entidade que relata, etc.)

CTI = Capacidade da Tecnologia de Informação

Há que se considerar, contudo, que no setor público dos países em desenvolvimento há um requisito básico adicional que deve ser considerado na equação, que é o apoio financeiro internacional (OUDA, 2004, p. 97). Assim, o Modelo de Requisitos Básicos (Basic Requirements Model - BMR) desenvolvido pelo pesquisador busca fornecer um panorama geral sobre os fatores que devem ser considerados no processo de mudança, conforme Figura 4. 
Figura 4 - Modelo de Requisitos Básicos para o sucesso da implementação do regime de competência na contabilidade pública dos países desenvolvidos e em desenvolvimento.

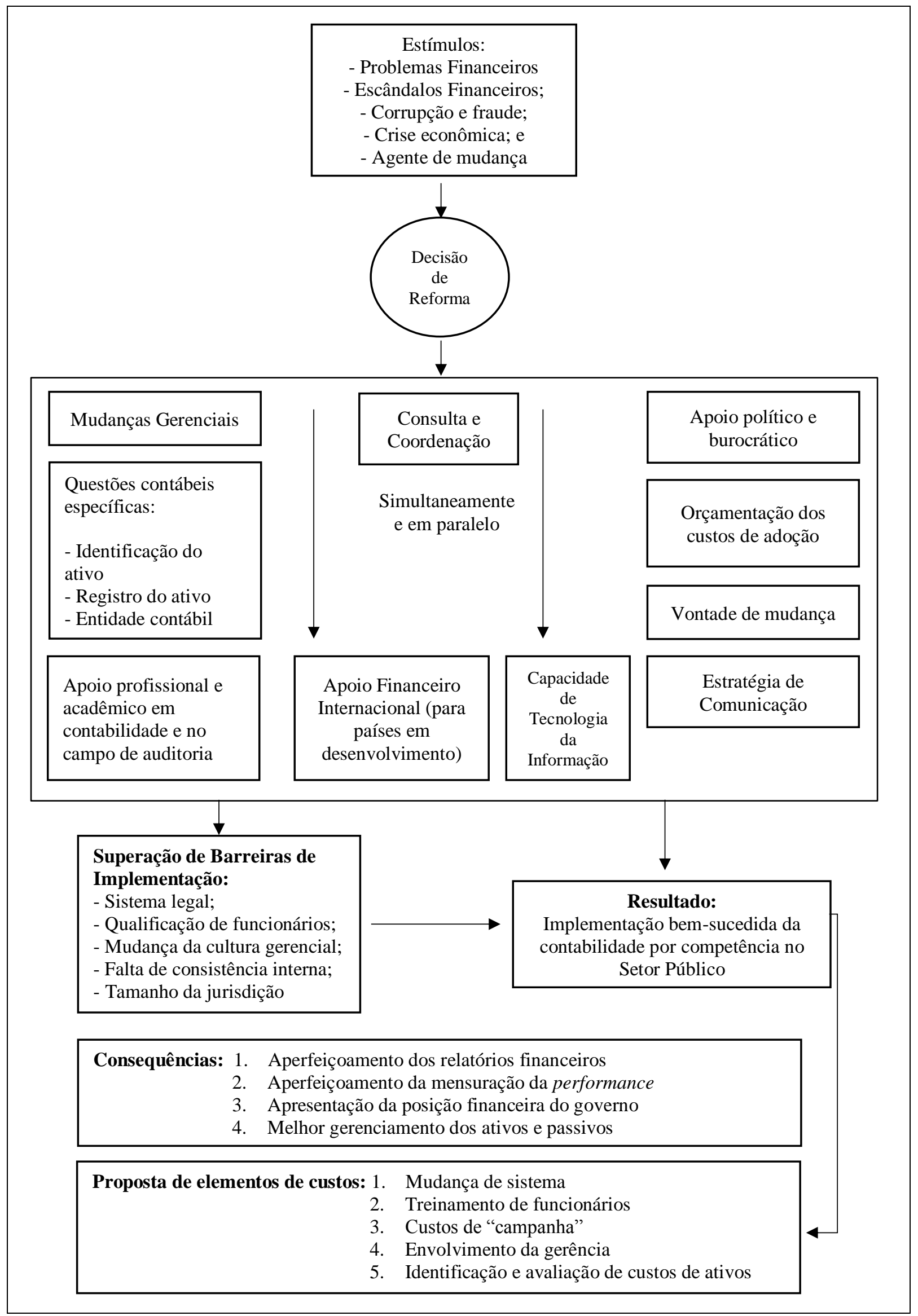

Fonte: Ouda (2004, p. 84), adaptado 
Dessa forma, a expectativa de Ouda é que seu Modelo de Requisitos Básicos complemente o Modelo de Contingência de Lüder, uma vez que este último destaca os fatores explicativos, ao passo que o primeiro identifica os fatores que facilitam o processo de implementação. Assim, a utilização dos dois permite uma melhor compreensão sobre o processo de mudança (OUDA, 2004).

Em 2010, Ouda desenvolve um novo modelo prescritivo para a implementação bemsucedida do regime de competência na contabilidade pública, reconhecendo que a transição para a contabilidade de competência envolve significativas mudanças culturais, administrativas e técnicas. Na visão do pesquisador, a reforma deve ser realizada em fases e o plano de progresso deve ser estabelecido desde o início e de maneira clara. Assim, o novo modelo consiste em três fases: a de tomada de decisão da reforma, a de transição e a fase de pós-transição (OUDA, 2010).

$\mathrm{O}$ autor ressalta que a criação de condições adequadas para a adoção do regime de competência no setor público não é suficiente para completar a mudança na prática, nesse sentido detalha quatro subfases que devem ser realizadas na fase de transição: fase de transição inicial; fase de fundação; fase de conversão; e fase de teste e confirmação.

Já no que se refere às reformas contábeis no setor público especificamente dos países emergentes, Van Helden e Ouda (2016) afirmam que estas são resultados da interação entre três grupos de fatores, como pode ser observado na Figura 5.

Figura 5 - Interação entre grupos de fatores que tem influência sobre práticas contábeis

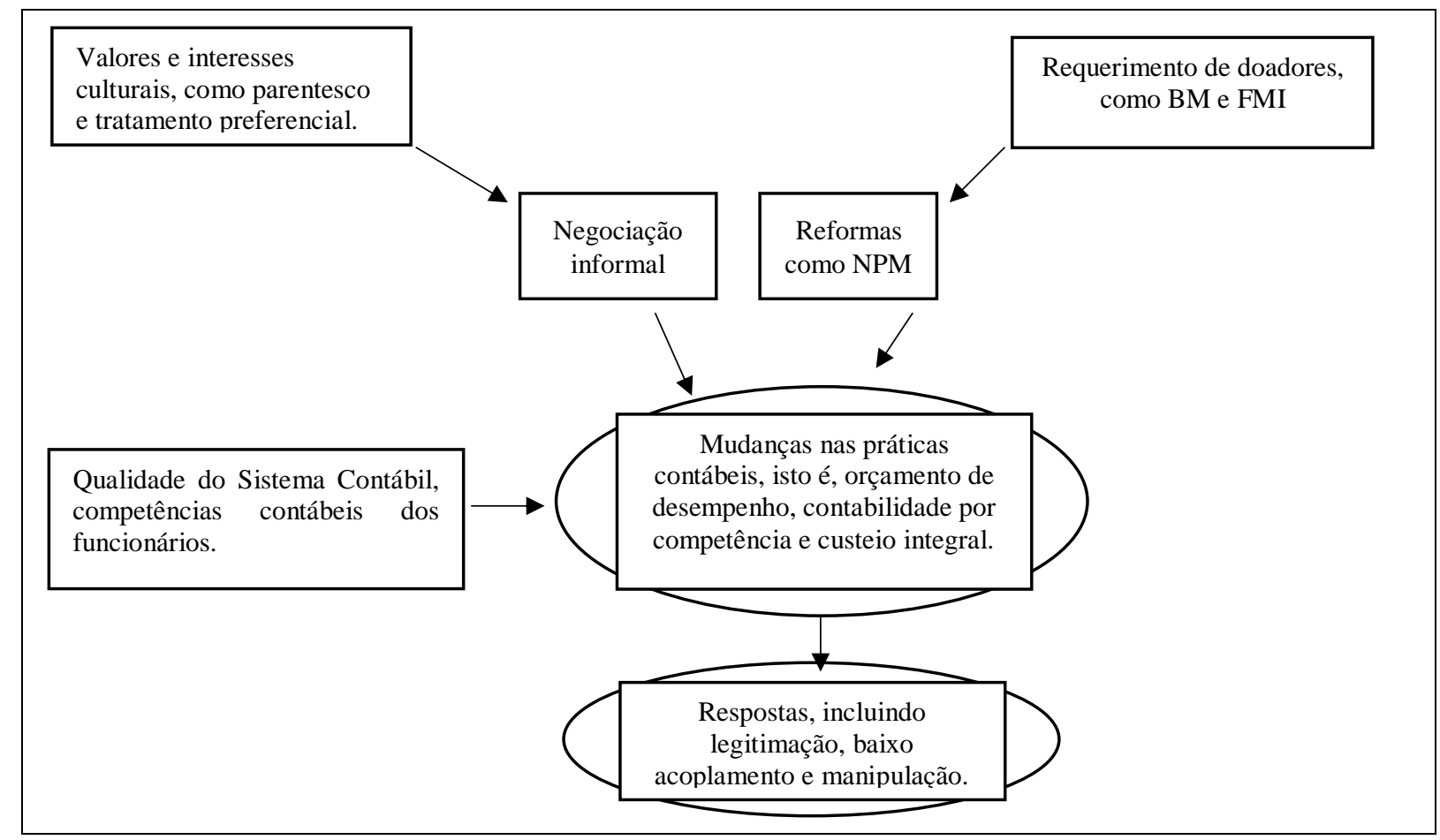

Fonte: van Helden e Ouda (2016, p. 1). 
Cabe ressaltar que os autores utilizam uma noção de economia emergente mais ampla, incluindo os países mais pobres do mundo. Assim, apontam que nessas economias geralmente não há capacidade institucional para adotar formas avançadas de orçamento e contabilidade, resultando em dificuldades tanto na adoção como no uso destes (VAN HELDEN; OUDA, 2016).

Alguns estudos relacionados à contabilidade aplicada ao setor público têm mostrado uma tendência crescente na adoção das IPSAS nesses países, como tentativa de imitar "melhores práticas" adotadas por organizações internacionais e os países ocidentais (ADHIKARI; GÅRSETH-NESBAKK, 2016). Portanto, há uma suposição geral de que países de economias subdesenvolvidas mudam suas práticas contábeis com a finalidade de uma impressão de modernização (ANTIPOVA; BOURMISTRO, 2013).

Diante do exposto, o que se observa em comum nos modelos retrocitados é um reconhecimento de que o ambiente influencia a forma e a maneira como as mudanças contábeis ocorrem, reforçando a visão de contabilidade como prática social e institucional (POTTER, 2005) e a aplicabilidade das contribuições da perspectiva institucional.

Ainda, os modelos apresentados incluem, além da questão do ambiente institucional, a influência dos atores. Quanto a estes, Gama, Duque e Almeida (2014) ressaltam não só a necessidade de participação dos atores envolvidos, como também a de compartilhamento de informação entre eles e de incentivo para que contribuam com o processo de implementação de mudanças.

A literatura tem utilizado esses modelos para descrever mudanças em contextos específicos (JORGE, 2005; VILLEGAS; JULVE, 2012) e para análises comparativas no setor público, tal como o estudo de Caba-Perez, López-Hernandez e Ortiz-Rodríguez (2009), que propõe, inclusive, uma adaptação ao modelo de Contingência de Lüder com vistas a analisar os efeitos de mudança do sistema político no sistema de informação financeira e sua reforma na Argentina, no Chile e no Paraguai, utilizando contribuições de Ouda (2001, 2004). Botelho e Lima (2015), ao analisar os requisitos e desafios dos países na transição para o regime de competência no setor público, baseiam-se nos procedimentos apontados no BRM de Ouda.

Tais modelos também têm sido aplicados em estudos que buscam descrever o processo de convergência para IPSAS. Por exemplo, Alesani, Jensen e Steccolini (2012) analisam, sob a ótica dos dois modelos de Lüder (Contingência e FMR), a reforma da primeira organização do sistema das Nações Unidas: o Programa Alimentar Mundial (PAM), na implementação das IPSAS por competência. 


\subsection{DISPOSIÇÃO INSTITUCIONAL DO ESTADO BRASILEIRO}

O Brasil é estruturado sob a forma federada de Estado, isto é, é integrado por diferentes entidades políticas: União, 26 Estados, Distrito Federal (DF) e 5.564 Municípios. Os entes federados brasileiros são dotados de autonomia política, nos termos da Constituição Federal (BRASIL, 1988). Segundo Mendes, Coelho e Branco (2010) essa forma revela-se interessante devido à diversidade existente em territórios amplos, e, assim, permite que o governo busque satisfazer as necessidades nacionais ao mesmo tempo em que considera outras peculiaridades mediante a atuação do governo local.

Nesse sentido, o modelo federativo pressupõe a repartição de competências tanto administrativas, como tributárias e legislativas entre os entes federados (MORAES, 2010). Para a repartição de competências, adotou-se como princípio a predominância do interesse, portanto, matérias de interesse predominantemente local foram atribuídas aos Municípios, as de interesse predominantemente regional foram destinadas aos Estados-membros e as de interesse predominantemente geral couberam à União. Assim, a competência para legislar sobre direito tributário, financeiro e econômico, compete concorrentemente à União, aos Estados e ao DF, de forma que a primeira edita lei de normas gerais enquanto os Estados e DF suplementam a legislação, editando normas específicas para atender às suas particularidades. Por fim, vale acrescentar que essa competência concorrente não inclui os Municípios, no entanto, eles podem suplementar a legislação federal e a estadual no que couber, conforme artigo 30 da Constituição Federal (BRASIL, 1988).

Quanto à organização da Administração Pública brasileira, essa é regulamentada pelo Decreto $n^{\circ}$ 200/1967. Segundo o referido decreto, a Administração Federal é dividida em: (i) Administração Direta, que é composta pelos órgãos que integram as pessoas políticas do Estado; e (ii) Administração Indireta, composta por autarquias, empresas públicas, sociedades de economia mista e fundações públicas. Além disso, o Decreto prevê normas de administração financeira e de contabilidade (BRASIL, 1967).

No que tange à forma de governo, tem-se que o Brasil adotou a forma republicana, caracterizada pela eletividade, temporalidade dos mandatos e necessidade de prestação de contas. O sistema de governo brasileiro é o presidencialista, marcado pela divisão dos Poderes (Executivo, Legislativo e Judiciário). O Presidente da República é o Chefe do Poder Executivo e exerce com auxílio de Ministros de Estado a direção da administração pública federal (ALEXANDRINO; PAULO, 2010).

Ressalta-se que a separação dos poderes não é absoluta, sendo que a própria 
Constituição Federal estabelece funções precípuas dos Poderes, prevendo também mecanismos de interferência para o controle da atuação estatal, de forma a assegurar um Sistema de Freios e Contrapesos (DI PIETRO, 2014). Uma das formas de controle estabelecidas é a fiscalização.

Assim, em relação à fiscalização, destaca-se que, no Brasil, é exercida pelo Congresso Nacional, mediante controle externo, cabendo ao Tribunal de Contas União (TCU) o deverpoder de auxílio a este controle, e também pelo sistema de controle interno de cada Poder, sendo realizada sob aspectos contábeis, financeiros, orçamentários, operacionais e patrimoniais (BRASIL, 1988). A estrutura do controle governamental brasileiro pode ser visualizada na figura 6.

Figura 6 - Estrutura do Controle Governamental no Brasil

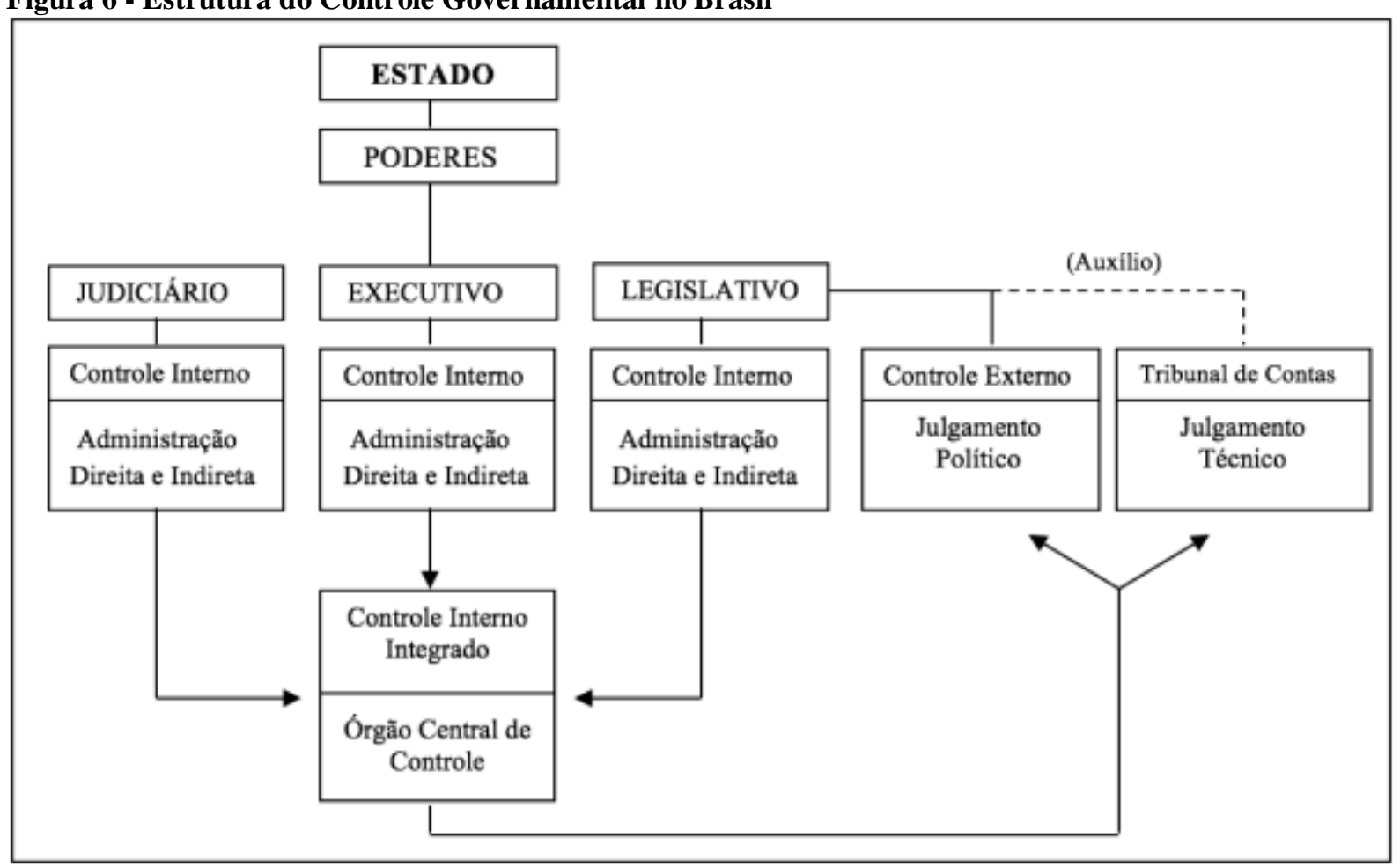

Fonte: Jund (2007, p. 191), adaptado.

Em relação à contabilidade pública, um importante marco foi a edição da Lei ${ }^{\circ} 4.320$, de 17 de março de 1964, que trouxe normas de direito financeiro para a elaboração e controle dos orçamentos e balanços dos entes. Para Giacomoni (2007, p. 48), a Lei $n^{\circ} 4.320$ foi além das normas gerais, abordando particularidades, especialmente na adoção do plano de contas para as três esferas. Lima, Santana e Guedes (2009), apontam a referida lei como o principal diploma legal da contabilidade pública no País.

Outro avanço foi a Lei Complementar $\mathrm{n}^{\mathrm{o}} 101$, de 4 de maio de 2000, também conhecida como Lei de Responsabilidade Fiscal (LRF) que definiu normas de finanças 
públicas com vistas a uma gestão responsável, ressaltando a necessidade de ações planejadas e transparentes para o equilíbrio das contas públicas, estabelecendo uma série de limites nos gastos públicos. Soares e Scarpin (2010) reconhecem a importância da LRF, no entanto, apontam que, na prática, a contabilidade pública no Brasil ainda se movia de acordo com regras defasadas, de caráter legalistas e carentes de mudança.

Diante das características do País, o sistema contábil brasileiro pode ser enquadrado no modelo continental (NIYAMA, 2009). De acordo com Niyama (2009), o modelo continental apresenta como características uma profissão contábil fraca e pouco atuante, bem como uma forte interferência governamental no estabelecimento de padrões contábeis.

Ademais, quanto à estrutura legal, o Brasil pode ser classificado como code law, em que há um alto grau de detalhamento das regras contábeis, e, segundo Niyama (2009), existe ainda uma certa falta de flexibilidade na preparação e apresentação de demonstrações contábeis, sendo que a ênfase das demonstrações é para os credores. Segundo Ladipo et al. (2009), os arranjos de gestão das finanças públicas nos países latino americanos foram influenciados pela herança política, legal e cultural da colonização, ou seja, pelo Direito Romano, em que as regras são codificadas e prescritivas. Apesar disso, ainda segundo os autores, a proximidade com os Estados Unidos tem influenciado o surgimento de uma estrutura institucional e legal híbrida.

Em relação à qualificação funcional, estudo realizado pela Escola Nacional de Administração Pública (ENAP, 2015) revela que no Poder Executivo a maioria dos servidores possui nível superior $(44,6 \%)$, seguido por servidores com nível médio ou técnico $(23,8 \%)$. Especificamente em relação aos profissionais contábeis, pesquisa realizada pelo Conselho Federal de Contabilidade (CFC, 2013) mostra que 45,7\% dos contadores possuem nível superior, e que 47,1\% possuem titulação máxima de pós-graduação lato sensu. Esse percentual reduz drasticamente quando se considera a pós-graduação stricto sensu, com apenas $6,3 \%$ titulados como mestre e $0,8 \%$ como doutores. Ademais, considerando o total de contadores, apenas $7,1 \%$ atuam no setor público.

Para Revoredo (2008), embora a qualificação funcional não demonstre ser obstáculo para a realização de reformas na administração pública, as características conservadoras dos agentes burocráticos do governo federal podem representar obstáculo para reformas governamentais, de maneira geral.

Quanto aos aspectos culturais, Lima (2016) ao analisar suas dimensões e seu impacto nas práticas contábeis no Brasil, conclui que os operadores da contabilidade também são conservadores, sendo que a aversão à incerteza e distância do poder são as dimensões 
culturais que mais impactam as práticas contábeis. Apesar de apresentar, historicamente, um Poder Legislativo e cidadãos pouco exigentes acerca do accountability de seus governantes, essas características do Estado brasileiro apresentam indícios de mudança, com uma tendência para que se amplie o nível de exigência (REVOREDO, 2008).

De maneira geral, a organização da administração pública brasileira e a maneira como é regulamentada, assim como aspectos da cultura, parecem não ser propícios a reformas, o que destaca a necessidade de definição de estratégias para condução do processo, tais como estratégias participativas e com implantação em múltiplas etapas (REVOREDO, 2008). A autora conclui que apesar de a adoção integral das IPSAS no País parecer o melhor caminho para atender as demandas internacionais, as características do Brasil demonstram uma maior propensão para a convergência aos padrões internacionais da IFAC. 


\section{PADRÃO IFAC}

Nesta Seção, apresenta-se o Padrão IFAC, detalhando como as IPSAS são emitidas e as experiências internacionais na adoção dessas normas, buscando apresentar o estímulo dos países para convergir às IPSAS, bem como as características institucionais e a atuação dos atores que influenciaram na condução do processo de reforma nos diversos países.

\subsection{DESENVOLVIMENTO DAS IPSAS}

Em que pese existir outros padrões contábeis internacionais aplicáveis ao setor público, como o padrão americano (ROYBARK; COFFMAN; PREVITS, 2012) e projeto de padrão europeu (BIONDI, 2014), a literatura aponta que o padrão IFAC se tornou referência internacional para o desenvolvimento de sistemas de contabilidade no setor público em todo o mundo, inclusive, Christiaens et al. (2015) argumentam que ela merece atenção tanto por parte daqueles que desenvolvem políticas contábeis quanto de profissionais e estudiosos.

A International Federation of Accountants (IFAC) surgiu em 1977 após o XI Congresso Mundial de Contadores, com o objetivo de desenvolver a profissão contábil internacionalmente. Na ocasião, o Comitê de Coordenação Internacional para a Contabilidade Profissão (ICCAP), formado em 1972, foi extinto (NOBES; PARKER, 2008).

Trata-se de uma organização global destinada à profissão contábil, composta atualmente de 175 membros e associados em mais de 130 países (IFAC, 2015). É estruturada por quatro órgãos normatizadores independentes, entre eles o International Public Sector Accounting Standards Board (IPSASB), que é responsável pela emissão das International Public Sector Accounting Standards - IPSAS (IFAC, 2016).

Apesar de parte da literatura questionar os benefícios da adoção da contabilidade pública por competência e das IPSAS (ADHIKARI; GÅRSETH-NESBAKK, 2016, p. 126), tendo em vista a baixa qualidade de informação financeira atualmente disponível para os gestores públicos em muitas jurisdições, para Sutcliffe (2003) é provável que os usuários internos sejam beneficiados com o desenvolvimento e aplicação destas normas. Além disso, segundo o pesquisador, a sua adoção também pode proporcionar maior eficiência e eficácia na auditoria e análise de relatórios financeiros governamentais, sendo, dessa forma, uma iniciativa importante para o fortalecimento da transparência financeira do governo e governança. 
Estudo da PricewaterCoopers (2015) mostra que atualmente há uma tendência para reformas de modernização contábil em todo o mundo, sendo que sete em cada 10 governos demonstram a intenção de utilizar o regime de competência nos próximos cinco anos, e que as IPSAS têm se destacado como referencial global para essas reformas.

Para Chan (2008), as IPSAS podem ser caracterizadas de diferentes maneiras: como uma versão internacional das normas nacionais, por serem substancialmente o modelo anglosaxão de contabilidade pública elevado ao nível internacional; ou como uma versão governamental das normas de contabilidade privada, isto é, das International Financial Reporting Standards (IFRS), definidas pelo International Accounting Standards Board (IASB), que também podem ser aplicáveis ao setor público.

Estudos esclarecem que o processo de elaboração das IPSAS pode ser visto em duas fases. Na primeira fase, compreendendo o período de 1996 a 2002, o IPSASB, essencialmente, importou as normas contábeis do setor privado, emitidas pelo IASB, realizando alterações relativamente pequenas. $\mathrm{Na}$ segunda fase, a partir de 2003, o comitê passou a focar temas mais particulares do setor público, como tributos e implicações do orçamento para relatórios financeiros (CHAN, 2010).

Acrescenta-se que o desenvolvimento inicial das IPSAS foi realizado com a colaboração do Asian Development Bank, do International Monetary Fund (Fundo Monetário Internacional - FMI), do United Nations Development Programme - UNDP e do World Bank (GRECO, 2008). Até dezembro de ano de 2016, o IPSASB havia desenvolvido 39 IPSAS, sendo 34 em vigor, conforme Quadro 1.

\begin{tabular}{|c|c|}
\hline Pronunciamentos & Descrição \\
\hline IPSAS 1 & Presentation of Financial Statements \\
\hline IPSAS 2 & Cash Flow Statements \\
\hline IPSAS 3 & Accounting Policies, Changes in Accounting Estimates and Errors \\
\hline IPSAS 4 & The Effects of Changes in Foreign Exchange Rates \\
\hline IPSAS 5 & Borrowings Costs \\
\hline IPSAS 6 & Consolidated and Separate Financial Statements \\
\hline IPSAS 7 & Investments in Associates \\
\hline IPSAS 8 & Interest in Joint Ventures \\
\hline IPSAS 9 & Revenue from Exchange Transactions \\
\hline IPSAS 10 & Financial Reporting in Hyperinflationary Economies \\
\hline IPSAS 11 & Construction Contracts \\
\hline IPSAS 12 & Inventories \\
\hline IPSAS 13 & Leases \\
\hline IPSAS 14 & Events after the reporting date \\
\hline IPSAS 15 & $\begin{array}{l}\text { Financial Instruments: Disclosure and Presentation (substituída pelas IPSASs } 28 \text { a } 30 \\
\text { a partir de 2013) }\end{array}$ \\
\hline IPSAS 16 & Investment Property \\
\hline IPSAS 17 & Property, Plant, and Equipment \\
\hline IPSAS 18 & Segment Reporting \\
\hline IPSAS 19 & Provisions, Contingent Liabilities and Contingent Assets \\
\hline
\end{tabular}




\begin{tabular}{|ll|}
\hline Pronunciamentos & Descrição \\
\hline IPSAS 20 & Related Party Disclosures \\
IPSAS 21 & Impairment of Non-Cash-Generating Assets \\
IPSAS 22 & Disclosure of Financial Information about the General Government Sector \\
IPSAS 23 & Revenue from Non-Exchange Transactions (Taxes and Transfers) \\
IPSAS 24 & Presentation of Budget Information in Financial Statements \\
IPSAS 25 & Employee Benefits \\
IPSAS 26 & Impairment of Cash-Generating Assets \\
IPSAS 27 & Agriculture \\
IPSAS 28 & Financial Instruments: Presentation \\
IPSAS 29 & Financial Instruments: recognition and measurement \\
IPSAS 30 & Financial Instruments: disclosures \\
IPSAS 31 & Intangible Assets \\
IPSAS 32 & Service Concession Arrangements: Grantor \\
IPSAS 33 & First-time Adoption of International Public Sector Accounting Standards (IPSAS) \\
IPSAS 34 & Separate Financial Statements \\
IPSAS 35 & Consolidated Financial Statements \\
IPSAS 36 & Investiments in Associates and Joint Ventures \\
IPSAS 37 & Joint Arrangements \\
IPSAS 38 & Disclosure of Interests in Other Entities \\
IPSAS 39 & Employee Benefits (irá substituir a IPSAS 25 a partir de 2018) \\
\hline
\end{tabular}

Fonte: IFAC. Disponível em: <www.ifac.org>.

Para Kutianski (2015), as IPSAS possuem correlação com as normas elaboradas pelo IASB (IAS/IFRS), exceto as IPSAS 22, 23 e 24, que abordam questões específicas do setor público, como, por exemplo, transferências e receitas de transações sem contraprestação ou receitas derivadas. Menezes Júnior et al. (2016), ratificam esse entendimento, mostrando que as diferenças entre as IPSAS e as IFRS estão relacionadas, em sua maior parte, à inclusão de termos específicos e à adaptação de nomenclaturas, para que a aplicação das IPSAS se torne mais clara nas entidades do Setor Público.

No que se refere ao procedimento de emissão das IPSAS, o IPSASB publica minutas para a discussão das normas propostas para consulta pública, e, eventualmente, lança chamada para comentários antes do desenvolvimento da minuta. Com essa ação, a entidade espera desenvolver normas que considerem as perspectivas dos afetados pelos pronunciamentos (CFC, 2010). Esse projeto conjunto na definição de um padrão internacional possibilita analisar as respostas de diferentes sistemas contábeis (LUTHARDT et al., 2008).

Uma característica importante das normas emitidas pelo IPSASB é que elas não são mandatórias, dessa maneira, a sua adoção ou não depende da intenção e realidade de cada país. A adoção das IPSAS tem sido estimulada baseada nos possíveis benefícios que estas geram, entre eles, a melhora na qualidade e comparabilidade das informações financeiras do setor público (CFC, 2010).

No entanto, vale destacar que, conforme estudo realizado em 2010, algumas jurisdições optaram por não aplicar as IPSAS, devido ao fato de elas serem relativamente 
desconhecidas e a primazia de seus próprios padrões contábeis (CHRISTIAENS; REYNIERS; ROLLÉ, 2010).

Ao analisarem o grau de conformidade das normas contábeis nacionais de diferentes países com as IPSAS, Benito, Brusca e Montesinos (2007) concluem que existe ainda uma diversidade de práticas contábeis nos países objeto da pesquisa, evidenciando que ainda não há uma harmonização contábil. Em seu estudo, os pesquisadores afirmam que os países que apresentaram maiores níveis de conformidade com as IPSAS (superior a 75\%) incluem a Nova Zelândia, Suécia, Austrália, Estados Unidos, México, Holanda e Reino Unido. Por outro lado, o grupo de países com baixa conformidade, isto é, inferior a 50\%, é composto de países como a Argentina, Canadá, Suíça, Áustria, Chile, Noruega e França.

Por outro lado, Christiaens et al. (2015) ressaltam que entre as razões para a adoção das IPSAS está a conformidade com as organizações internacionais, como, por exemplo, a Organização para a Cooperação e Desenvolvimento ou Econômico - OCDE. Chan (2010) aponta que as referidas normas fornecem "um mecanismo de coordenação para reduzir os custos de accountability", sendo essa a possível razão pela qual os organismos internacionais têm apoiado o processo de adoção das IPSAS.

A partir dos principais fatores institucionais apontados na literatura como capazes de influenciar os sistemas contábeis (NOBES; PARKER, 2004; PINA; TORRES; YETANO, 2009; ZEFF, 2012), Christiaens et al. (2015) concluem que há uma tendência mais forte de aplicação das IPSAS por competência nos países com sistemas legislativos burocráticos, com estilo democrático de participação dos cidadãos, com uma forte tradição de contabilidade, com uma harmonização vertical e com um sistema financeiro centralizado. Os autores apontam que na América Latina os sistemas legislativos são burocráticos e o sistema financeiro centralizado, entretanto, os outros fatores não são observados nessa região.

Para Gomes, Fernandes e Carvalho (2015), quando o sistema de informação atual é considerado aceitável e é capaz de responder as demandas de informação, a necessidade de mudança é reduzida. No que se refere ao estímulo para adoção das IPSAS, os pesquisadores apresentam que as pressões institucionais e a combinação de forças coercitivas, normativas e miméticas são determinantes no processo de mudança. Assim, os achados de seus estudos mostram as mudanças na contabilidade pública como uma consequência do um contexto institucional e político favorável para a adoção das IPSAS. 


\subsection{EXPERIÊNCIAS INTERNACIONAIS NA ADOÇÃO DAS IPSAS}

A adoção das IPSAS pelos diversos países tem sido crescente, especialmente devido às recomendações para a implementação de competência nos governos realizadas por organismos internacionais, tais como o Banco Mundial e o FMI. Nesse sentido, Brusca, Gómez-Villegas e Montesinos (2016) destacam que as experiências de países pioneiros podem servir como lição para os outros.

Como as IPSAS foram criadas para que a informações de qualidade sejam fornecidas nos relatórios financeiros, especialmente nos países em desenvolvimento, incluindo os da América Latina, Pérez e Hernández (2007) afirmam que para a realização de mudança a atual qualidade dos relatórios financeiros públicos apresentados pelos governos centrais dos países latino-americanos deve ser insuficiente. Assim, ao estabelecer em que medida as práticas de relatórios financeiros públicos adotadas pelos países latino-americanos convergem com as recomendadas pelo IFAC, os pesquisadores concluem que apenas a Argentina, Colômbia, Panamá e Peru conseguiram atingir a $50 \%$ das informações a serem apresentadas como recomendado pelas IPSAS.

Pérez e Hernández (2007) apontam também que no âmbito do projeto "Transparência das Contas Públicas", assinado em 2000, envolvendo o Banco Interamericano de Desenvolvimento (BID) e a Associação Interamericana de Contabilidade (IAC), a adoção das IPSAS foi destacada como necessária para alcançar a harmonização e a comparabilidade dos relatórios financeiros.

Na Espanha, destaca-se a influência do Tribunal de Contas, instituição suprema de auditoria (SAI), que, pela primeira vez, em 2006, fez uma recomendação sobre normas de contabilidade, solicitando a harmonização de normas de contabilidade pública. Isso resultou em uma moção parlamentar para o estudo de viabilidade da adoção de um sistema harmonizado para todas as entidades (BRUSCA; MONTESINOS; CHOW, 2013). Enquanto o partido político no poder espanhol era favorável à adoção das IPSAS, a oposição desejava a adaptação das normas do setor privado (IFRS). Ao fim do estudo, os pesquisadores não puderam concluir sobre o resultado da adoção das IPSAS no País.

Adhikari e Mellemvik (2010) analisam como e em que medida os países sul asiáticos têm planejado as mudanças contábeis em direção às IPSAS, evidenciando uma maior tendência de adaptação em detrimento da adoção IPSAS. Como utilizam a perspectiva institucional, exploram ainda o papel das instituições financeiras internacionais, como o Banco Mundial e o FMI, apontando-o como determinante para disseminar IPSAS em países 
em desenvolvimento. No caso analisado pelos autores, essas instituições criaram um mito de que a contabilidade por competência não poderia ser introduzida antes de se possuir conformidade com as IPSAS por regime de caixa. Isso é demonstrado a partir da experiência da Maldivas, do Paquistão e da Sri Lanka que, apesar de já estarem em um processo em direção ao regime de competência, tiveram de aceitar as IPSAS por regime de caixa.

Villegas e Julve (2012) apontam que, na Colômbia, os principais condutores da reforma da contabilidade pública foram os membros do governo, em especial, o Contador Geral da Nação e o Ministro da Fazenda, influenciando diretamente no conceito e na estratégia adotados. Segundo os autores, a atuação do órgão de controle externo tem se mostrado determinante para o impulsionar os gestores na implementação da nova contabilidade, no entanto, observa-se ainda uma falta de interesse por parte de outros membros do governo.

No caso da Rússia, Antipova e Bourmistro (2013) relatam que mesmo após transcorrido vários anos do início da reforma, o processo no país ainda se encontra em um estágio inicial. Os resultados apresentados, baseados em levantamentos e entrevistas, mostram uma figura de contadores públicos que ainda não tem conhecimento dos objetivos e benefícios da reforma e estão relutantes para "desaprender" as antigas tradições contábeis, isto é, a fim de desinstitucionalizar a tradição antiga baseada na cultura de compliance. As autoras defendem a necessidade de a comunidade epistêmica desempenhar o papel de "embaixadores de contexto", mediando conhecimento que permita a efetiva transformação das ideias da reforma em prática local.

Já na Costa Rica, Leandro (2014) analisa as ações realizadas pelo país à luz do modelo de Requisitos Básicos formulado por Ouda (2004). No que tange ao prazo do processo, tem-se que apesar de o primeiro decreto, emitido em 2008, estabelecer que a implementação das IPSAS deveria estar consolidada a partir de 1 de janeiro de 2012, houve uma prorrogação do prazo até o exercício de 2016. Todavia, considerando que no Reino Unido e Nova Zelândia o processo durou mais de seis anos, o autor defende prazos maiores para a implementação de inovações. Dessa maneira, conclui que as ações realizadas pelo país favorecem o sucesso no processo de implementação das IPSAS.

Oulasvirta (2014) analisa a relutância da adoção das IPSAS na Finlândia, demostrando que não houve envolvimento e interesse político no processo de reforma da contabilidade pública. Isso aliado a certa relutância do país e uma fraca coerção normativa e mimética, revelou a falta de sucesso nas reformas.

No caso de Malta, apesar de ter iniciado o processo de reforma para a contabilidade 
por competência em 1999, apenas em 2011 é que houve a decisão de adoção integral das IPSAS. O país desenvolveu suas normas (Accounting standards for the Government of Malta - MGAS) em 2002, baseadas nas IPSAS e nas IAS (International Accounting Standards, as atuais International Financial Reporting Standards - IFRS), mas, de acordo com o ContadorGeral, elas não tinham uma "marca", portanto, não forneciam a credibilidade requerida pelo país. A decisão para adoção das IPSAS foi influenciada por uma mudança no ator principal do processo e por pressões institucionais (JONES; CARUANA, 2015).

Em Portugal, observou-se a insatisfação de diversos atores diante dos diferentes regimes e ritmos de adoção de mudanças contábeis nos subsetores do governo. Esse contexto, aliado a pressões externas, especialmente devido a grande dependência do país de instituições financeiras, serviram como estímulo favorável para a adoção das IPSAS (GOMES; FERNANDEZ; CARVALHO, 2015). Ao explorar o processo de mudança em direção às IPSAS, os autores ressaltam a necessidade de cooperação entre os diversos grupos interessados no processo.

Na visão de Brusca, Gómez-Villegas e Montesinos (2016), há uma tendência internacional à adoção das IPSAS em países latino-americanos, embora existam obstáculos comuns para o atingimento das metas da reforma como, por exemplo, a necessidade de capacitação e tecnologias para a implementação. Ao analisar o estímulo determinante no processo de harmonização ou adoção das IPSAS, os autores mostram que o Peru e a Colômbia, considerados os países pioneiros na aplicação das referidas normas na América Latina, tinham como objetivo a modernização dos sistemas contábeis, com vistas ao aumento de transparência no uso dos recursos públicos.

Sob a ótica da teoria institucional, a pesquisa aponta que a adoção das IPSAS tem ocorrido principalmente por isomorfismo mimético, com alguns componentes de isomorfismo normativo. Ressalta-se que o National Audit Office (NAO), órgão superior de fiscalização de contas, do Peru e a Colômbia tiveram um papel importante no processo ao apontar as insuficiências do sistema de contabilidade governamental desses países (BRUSCA; GÓMEZVILLEGAS; MONTESINOS, 2016).

Adhikari e Gårseth-Nesbakk (2016) utilizam a perspectiva neoinstiucional para reconhecer a perspectiva de atores envolvidos na implementação das IPSAS por competência em países membros da OCDE. Ao demonstrar que os países analisados subestimaram a complexidade da implementação da contabilidade por competência, os referidos autores ressaltam a necessidade de desenvolver uma cooperação entre os atores, tanto no nível econômico, como no político e no organizacional. 
No que tange às estratégias de implementação para adoção ou adaptação de sistemas dos países da América Central às IPSAS, Leandro, Pérez e Hernandez (2016) afirmam que em El Salvador, Honduras, Guatemala, Nicarágua e Panamá o processo tem sido conduzido basicamente pelo órgão regulador contábil, de forma centralizada, com pouca participação de acadêmicos, organizações profissionais e auditores externos.

Ao analisar a situação da região sob análise, os autores apontam a Costa Rica como o país mais avançado no que diz respeito à mudança em direção as normas internacionais da IFAC e inovação de seus sistemas contábeis, mostrando os avanços realizados pelo país do ponto de vista regulatório e de implementação prática mediante desenvolvimento de planos de ação, treinamentos de competências específicas e contratação de consultoria (LEANDRO; PÉREZ; HERNANDEZ, 2016). Assim, o estudo revela a importância do planejamento do processo de convergência ao afirmar que as ações realizadas pelo país refletiram num maior nível de convergência das demonstrações contábeis às IPSAS 1 e 2.

Ainda segundo Leandro, Pérez e Hernandez (2016), em nenhum dos países da América Central houve uma estimativa adequada acerca dos custos relacionados ao processo de implementação das IPSAS, impedindo, consequentemente, uma alocação específica de recursos para tal. Ao analisar a similaridades das informações disponibilizadas pelos países com as recomendações feitas nas IPSAS, os autores concluíram que ainda não se atingiu um nível de convergência alto nesses países.

O próprio IPSASB retratou a experiência de alguns países na adoção de suas normas. De acordo com o Board, no caso da Guatemala o processo foi descontinuado devido a questões financeiras e de comprometimento, sendo constituído, no ano de 2011, um comitê com o objetivo de institucionalizar as normas contábeis internacionais no país (IFAC, 2013a). No caso da Costa Rica, o primeiro passo dado foi a alteração do arcabouço legal, no entanto, os prazos fixados inicialmente não eram baseados em um plano de implementação, e o país se deparou com o desafio de mudanças culturais, especialmente no que diz respeito à cultura contábil versus cultura orçamentária, a resistência às mudanças e integrações de sistemas e informações. Entre as lições aprendidas o país ressalta a necessidade de apoio político e de participação ativa dos gestores (IFAC, 2014a). Nessas experiências retratadas pela IFAC, há o reconhecimento geral de que o processo é lento e gradual.

Na Malásia, as normas utilizadas no nível federal são baseadas nas IPSAS por competência, sendo que as IPSAS por regime de caixa já eram utilizadas desde 2005 . Na condução do processo no país, há também a figura de um Comitê, no caso o Government Accounting Standards Advisory Committee (GASAC), que tem atuando levando em conta 
cronograma e recomendações do FMI (IFAC, 2013b).

Na Suíça, a necessidade de obtenção de informações mais abrangentes acerca da situação do governo, pelo parlamento e pelo público, ensejou a tentativa de se harmonizar o framework contábil dentro do próprio país, considerando os outros níveis de governo. Assim, em 2001, foi iniciado um processo de revisão do sistema contábil suíço com base nas IPSAS. Destaca-se que, no país, os membros do parlamento mostraram envolvimento com o projeto desde o início, sendo que os novos orçamentos e demonstrações financeiras, com base no regime de competência, foram intensamente debatidos nas comissões parlamentares (IFAC, 2014b).

Harun et al. (2016) mostram que a promoção do uso das IPSAS na Indonésia, a nível econômico ocorreu devido a razões econômicas (déficit fiscal na década de 80), além de uma busca de maior semelhança às práticas adotas por países desenvolvidos. A nível político, a adoção formal das IPSAS pode ser relacionada ao colapso do regime autoritário no país em 1998. A nível organizacional, a adoção é relacionada ao papel crescente de atores não governamentais e as implicações de suas ações no processo de reforma contábil. Assim, os achados do estudo confirmam que as ações dos atores não influenciam apenas os aspectos técnicos da contabilidade, mas também na extensão da internalização na adoção de um sistema contábil (HARUN et al., 2016).

Dessa forma, pode-se observar que apesar de haver resistências, há uma tendência em direção a adoção das IPSAS, até em razão da ausência de outro padrão no setor público com o intuito de regulação internacional. E os principais promotores desse modelo têm sido órgãos supranacionais e multilaterais, tais como a Organização do Tratado do Atlântico Norte (OTAN) e a Organização das Nações Unidas (ONU), que têm aplicado as IPSAS em seus sistemas de informação com vistas a contribuir com a legitimidade destas normas (BRUSCA, GÓMEZ-VILLEGAS, MONTESINOS, 2016).

Para obter uma relação atualizada dos países que utilizam ou estão em processo de adoção às IPSAS, foi enviado e-mail no mês de janeiro de 2016 ao comitê do IPSASB, sediado em Toronto no Canadá. De acordo com a lista obtida (Anexo A), mais de 70 jurisdições estão nessa condição, considerando as IPSAS por competência, e o processo de convergência às IPSAS por competência no Brasil está em andamento tanto no nível nacional, como no estadual e municipal. 


\section{METODOLOGIA}

Nesta Seção são apresentados os aspectos metodológicos empregados nesta pesquisa, mostrando as classificações da pesquisa e descrevendo a coleta e tratamento dos dados.

\subsection{CARACTERIZAÇÃO DO ESTUDO}

No que concerne aos objetivos, a presente pesquisa classifica-se como explicativa, uma vez que busca analisar, interpretar e identificar os fatos e suas causas (PRODANOV; FREITAS, 2010). Para Kuark, Manhães e Medeiros (2010), a pesquisa explicativa exige maior investimento em reflexão a partir do objeto de estudo, e visa identificar os fatores que contribuem para a ocorrência dos fenômenos, explicando o porquê das coisas.

Quanto à abordagem do problema, esta pesquisa classifica-se como qualitativa, pois, nesse tipo de pesquisa, concebem-se análises mais profundas em relação ao objeto de estudo, sem o emprego de um instrumento estatístico como base do processo de análise do problema (RAUPP; BEUREN, 2006). Em muitos casos, a pesquisa qualitativa mostra-se como a mais efetiva para a condução de investigações empíricas que buscam uma melhor compreensão de um fenômeno em seu contexto (BERDÁRD; GEDRON, 2004)

Em termos procedimentais, a pesquisa foi desenvolvida mediante análise bibliográfica e documental, com suporte de entrevistas e questionários. A estratégia metodológica de estudo de caso foi adotada, tendo em vista que consiste em uma investigação empírica e compreende um método de planejamento, coleta e análise de dados que revela ser adequado para descrever de maneira ampla e mais aprofundada determinado fenômeno social (YIN, 2010).

Previts, Parker e Coffman (1990) esclarecem que os estudos de caso oferecem uma grande relevância na apresentação e explicação de situações complexas. Na visão de Ventura (2007), a retratação profunda e de maneira abrangente da realidade, assim como o uso de múltiplas fontes de informação e a possibilidade de obtenção de diferentes pontos de vista sobre o objeto de estudo, são características apontadas como fundamentais em estudos de caso com enfoque qualitativo. Tal metodologia, segundo Soeiro $(2015$, p. 88$)$ tem sido bastante utilizada, tanto internacionalmente, como nacionalmente, em pesquisas contábeis que adotam a perspectiva institucional. Neste estudo, foi feito um estudo de caso único, obedecendo a lógica de replicação detalhada na Seção 4.2. 
Assim, para triangular os dados, foram realizadas entrevistas para a coleta de informações atualizadas do estágio recente da reforma da contabilidade pública no Brasil, fornecendo, ao mesmo tempo, uma visão histórica desde o início do processo, tendo em vista a escolha dos entrevistados. As entrevistas foram semiestruturadas (Apêndice A), trazendo como vantagem a obtenção de um maior direcionamento para o tema, permitindo uma cobertura mais profunda sobre determinadas questões, inclusive as mais complexas (BONI; QUARESMA; 2005). Ressalta-se que as entrevistas foram gravadas e utilizou-se o software NVivo para subsidiar a análise.

Em um segundo momento, foi realizada a aplicação de questionários, visando corroborar com as informações coletadas junto aos atores entrevistados. Os questionários permitem uma economia de tempo e obtenção de grande número de dados; maior liberdade nas respostas, devido ao anonimato; menos risco de distorção, em razão da não influência do pesquisador; e mais uniformidade na avaliação, dada a natureza impessoal do instrumento (MARCONI; LAKATOS, 2003).

Tratando-se de uma abordagem qualitativa, o método escolhido para a análise das entrevistas e dos questionários foi a análise de conteúdo. Bardin (2009) a define como um conjunto de técnicas de análise das comunicações, que possibilita a inferência de conhecimentos relacionados às variáveis inferidas das mensagens.

\subsection{COLETA E TRATAMENTO DOS DADOS}

A primeira etapa do trabalho consistiu em uma revisão bibliográfica e documental sobre o processo de convergência brasileiro, que, além de fornecer informações que susbsidiariam o desenvolvimento de um panorama do processo no país, permitiu identificar os principais atores promotores e direcionadores da reforma. Dessa forma, utilizou-se leis, decretos, portarias e demais normativos emitidos.

Em seguida, foi feita uma pesquisa nos sites institucionais dos atores com os termos "contabilidade pública", "convergência" e termos similares, a fim de se obter informações oficiais sobre o processo, possibilitando, especialmente, por meio das notícias divulgadas, obter detalhes do processo de convergência. Também foram levadas em consideração diversas apresentações realizadas por esses atores acerca do processo de convergência, disponíveis na internet. Após esse levantamento, foi desenvolvida uma linha temporal dos principais normativos da contabilidade pública brasileira e do processo de convergência às normas internacionais no País. 
Tendo em vista o conceito de influência defendido por Robert Dahl (1958), onde "A tem poder sobre B, na medida em que ele pode levar B a fazer algo que, de outra forma, não faria", partiu-se da premissa de que quanto mais ações são realizadas pelo ator, maior a sua capacidade de influência. Dessa forma, buscou-se identificar as ações realizadas pelos atores, sendo consideradas a emissão de documentos (normativos e outras publicações), a realização de cursos de capacitação e disseminação, acordos de cooperação técnica, parcerias, entre outros.

Apesar de a revisão da literatura e análise dos sites institucionais ter permitido a identificação de algumas ações realizadas, para complementá-las foi solicitado aos principais atores identificados no estudo dados de ações realizadas com vistas à implementação do processo de convergência da contabilidade pública aos padrões internacionais, mediante pedido de informações via Sistema Eletrônico do Serviço de Informação ao Cidadão (e-SIC), nos meses de julho e agosto (Apêndice D). Essa etapa adicional tornou-se necessária tendo em vista que o grau de disponibilização de informações divergia nos sites dos atores, de forma, que a análise meramente a partir dessas informações divulgadas poderia afetar os resultados desta pesquisa. Assim, buscou-se captar outras ações que porventura não foram divulgadas.

No entanto, em alguns casos, as respostas não se mostraram satisfatórias, considerando o objetivo da pesquisa. Assim, levando em conta ainda a escassez de literatura sobre o estágio recente da reforma nos países da América Latina (BRUSCA; GÓMEZ-VILLEGAS; MONTESINOS, 2016), a realização de entrevistas mostrou-se imprescindível para fornecer um panorama do processo e responder à questão de pesquisa.

Dessa forma, escolheu-se um representante para cada um dos atores considerados como principais na condução do processo de convergência, assim, foram realizadas três entrevistas (Apêndice B). As entrevistas tiveram uma duração média de uma hora e 30 minutos.

A escolha do representante do CFC foi baseada no número de participações desse profissional nos grupos de estudo e de trabalho na área pública do Conselho (Anexo D). Dessa forma, entrevistou-se via telefone, em agosto de 2016, o Sr. Joaquim Osório Liberalquino Ferreira.

O representante da Secretaria do Tesouro Nacional (STN) foi o Sr. Leonardo Silveira do Nascimento, que, além de ser o Coordenador-Geral de Normas de Contabilidade Aplicadas à Federação do referido órgão, é membro do Grupo Assessor do CFC das Normas Brasileiras de Contabilidade Aplicadas ao Setor Público e também representante do CFC no IPSASB/IFAC, possuindo um papel tríplice que permite uma visão detalhada do processo. A 
entrevista foi realizada pessoalmente em setembro de 2016, na cidade de Brasília.

O entrevistado do Tribunal de Contas da União (TCU) foi o Sr. Laércio Mendes Vieira, tendo em vista que atuou como representante do TCU junto ao Grupo de Trabalho da Convergência em Contabilidade Aplicada ao Setor Público do CFC. A entrevista foi realizada pessoalmente em setembro de 2016, também na cidade de Brasília.

Posteriormente, levantou-se a trajetória dos principais atores identificados. Foram analisadas questões relacionadas à motivação para a mudança, ações implementadas, planejamento, resultados obtidos e esperados com tais ações, bem como as dificuldades encontradas. A escolha desses itens de análise se deu em razão dos principais pontos em comum trazidos pelos modelos de Lüder (2001) e Ouda (2004, 2010), tais como estímulo e estratégia de implementação, tendo sido considerados, nesta pesquisa, variáveis úteis para análise da mudança e sua institucionalização.

Visando a triangulação dos dados, ainda foi aplicado questionário na reunião do GTCON, realizada em 11 de novembro de 2016, na Escola de Administração Fazendária (ESAF), na cidade de Brasília. A escolha de aplicação do instrumento de coleta de dados no referido evento foi motivada pelo fato de as reuniões do GTCON já contemplarem diversos atores envolvidos nas discussões acerca do processo de convergência, além da dificuldade operacional de obtenção de respostas no envio de questionários via internet. Considerando os 149 presentes na data de aplicação dos questionários, obteve-se 63 respostas, representando uma taxa de resposta de $42 \%$.

O questionário foi estruturado em três partes: (i) Perfil do Entrevistado, (ii) Processo de Convergência no Brasil e (iii) Atores (Apêndice C). Na primeira parte, buscou-se identificar características dos interessados no processo de convergência, especialmente o setor de atuação profissional e quantidade de participações em cursos e capacitações sobre a Contabilidade Aplicada ao Setor Público.

$\mathrm{Na}$ segunda parte, buscou-se captar percepções acerca das razões que levaram o governo brasileiro a decidir introduzir as IPSAS, dos efeitos e resultados observáveis e de possíveis dificuldades na implementação das normas internacionais no País, visando comparar com as informações obtidas junto aos principais atores envolvidos na promoção e condução do processo de convergência brasileiro.

$\mathrm{Na}$ segunda parte, buscou-se captar percepções acerca das razões que levaram o governo brasileiro a decidir introduzir as Normas de Contabilidade Aplicadas ao Setor Público, dos efeitos e resultados observáveis e de possíveis dificuldades na implementação das normas baseadas nos padrões internacionais. Dessa forma, foi possível comparar as 
percepções dos diversos atores envolvidos com as informações obtidas junto aos principais atores na promoção e condução do processo de convergência brasileiro.

Por fim, na terceira parte do questionário, buscou-se captar a percepção acerca da interação dos atores envolvidos na convergência da contabilidade pública, além de outros itens relacionados com a promoção e condução do processo. Primeiramente, foi feita uma pergunta aberta, buscando não influenciar as respostas, dos principais atores no processo de convergência brasileiro. Posteriormente, utilizando a escala Likert, de cinco pontos, buscou-se captar a percepção acerca da influência dos seguintes atores no processo: academia (universidades), CFC, STN, TCU e TCs com vistas a corroborar com a análise da pesquisa. Ressalta-se que os respondentes poderiam acrescentar outros atores além desses retrocitados, caso achassem relevante. Deixou-se, inclusive, um espaço permitindo que realizassem comentários adicionais, caso desejassem, sobre o processo de convergência e a atuação dos atores.

Os dados das questões que utilizaram a escala Likert foram analisados primeiramente pela demonstração da participação de cada alternativa em relação à respectiva questão e do cálculo do Ranking Médio (RM). As questões abertas foram analisadas utilizando análise de conteúdo e com suporte do NVivo para identificação das palavras mais utilizadas e da árvore de palavras.

Dessa forma, similarmente ao estudo de Jones e Caruana (2015), utilizou-se múltiplas fontes de dados como objetivo trazer várias perspectivas para dar suporte a análise e, consequentemente, a conclusão. A triangulação de evidência documental com oral possibilitou o aumento da confiabilidade e validade dos achados devido à evidência corroborativa. 


\section{A INFLUÊNCIA DOS ATORES NO PROCESSO DE CONVERGÊNCIA DA CONTABILIDADE PÚBLICA NO BRASIL}

Esta Seção tem como objetivo fornecer um panorama do processo de convergência às normas internacionais, desenvolvendo uma linha temporal dos principais normativos da contabilidade pública brasileira, com a identificação dos principais atores envolvidos nesse processo e sua trajetória. Posteriormente, é analisada a influência dos atores envolvidos no processo de convergência da contabilidade pública no Brasil.

\subsection{PANORAMA DO PROCESSO DE CONVERGÊNCIA BRASILEIRO}

No que diz respeito à convergência em si, do ponto de vista institucional, a primeira iniciativa se deu no ano de 2004, com a publicação da Portaria CFC n 37 , que instituiu um grupo de estudos com a missão de elaborar as primeiras normas brasileiras de contabilidade aplicadas ao Setor Público, integrado por membros do CFC, da STN e Secretaria Executiva do Ministério da Fazenda (FEIJÓ; BUGARIM, 2008; VICENTE; MORAIS; PLATT NETO, 2012; DINIZ et al., 2015).

Em 2007, foi publicado o documento intitulado "Orientações Estratégicas para o Desenvolvimento da Contabilidade Pública do Brasil", com vistas a reafirmar a contabilidade pública como ciência e o patrimônio como seu objeto de estudo, fundamentada em três diretrizes: a promoção e ao desenvolvimento conceitual, a convergência às normas internacionais, o fortalecimento institucional da Contabilidade, sendo que cada diretriz se desdobra em macro objetivos.

$\mathrm{Na}$ visão do CFC (2007) as IPSAS dispõem sobre uma contabilidade patrimonial integral e estabelecem o regime de competência para o reconhecimento de receitas e despesas. De acordo com a entidade, sem a adoção do regime de competência diversos ativos e passivos podem não ser reconhecidos, e o objetivo de evidenciar a situação financeira e os resultados do exercício fica fortemente prejudicado (CFC, 2007; CRUVINEL; LIMA, 2011; FRAGOSO et al., 2012; MACHADO; HOLANDA, 2010; CHAN, 2010).

Neste mesmo ano, por meio da Resolução CFC n ${ }^{\circ} 1.111$, foi apresentada pela primeira vez a interpretação dos Princípios de Contabilidade sob a perspectiva do Setor Público, considerando que as novas demandas sociais estavam a exigir um novo padrão de informações geradas pela Contabilidade Pública, de forma a facilitar a adequada interpretação e acompanhamento dos fenômenos patrimoniais, orçamentários, dos resultados econômicos e 
do fluxo financeiro. Ainda em 2007, houve a emissão de portarias da STN n 135 e 136 que criaram o GTREL e o GTCON.

Em 2007, foi criado o Comitê Gestor da Convergência, mediante Resolução CFC n ${ }^{\circ}$ 1.103/07, sendo composto, entre outros, pelo grupo de estudos da área pública. Inicialmente, buscava-se realizar ações que possibilitassem a convergência na área pública até 2012.

Em 25 de agosto de 2008, o Ministério da Fazenda editou a Portaria $n^{\circ}$ 184, dispondo sobre diretrizes a serem observadas pelos entes públicos para convergir às Normas Internacionais de Contabilidade Aplicadas ao Setor Público. Para Feijó e Bugarim (2008), a Portaria MF nº 184/2008 tinha como objetivo aumentar o nível de institucionalização do processo, prevendo, tacitamente, que a STN, como órgão central do Sistema de Contabilidade Federal, conduzisse o desenvolvimento das ações de convergência às Normas Internacionais de Contabilidade de Contabilidade da IFAC e às Normas Brasileiras de Contabilidade aplicadas ao Setor Público editadas pelo CFC.

Considerando o Ofício n 1920/08/COTEC-CFC, de 28 de setembro de 2008, em que o CFC solicitava apoio do TCU ao projeto de modernização da contabilidade pública (materializado nas Orientações Estratégicas), foi celebrado um acordo de cooperação entre o CFC e o TCU, com o objetivo de promover tanto o desenvolvimento conceitual como o fortalecimento institucional da contabilidade pública brasileira e o estímulo à convergência às normas internacionais. Ressalta-se que o acordo de cooperação não teve prazo de vigência determinado, ficando este condicionado à finalização da implantação das Normas Internacionais de Contabilidade aplicadas ao Setor Público no País. Também foi assinado pelo CFC juntamente com a ATRICON/ABRACOM e o IRB Termo de Cooperação Técnica com a finalidade de capacitação abrangendo os Princípios Fundamentais de Contabilidade sob a perspectiva do Setor Público e as NBC T 16.

Ainda em 2008, por meio da Portaria no 253 do TCU, a Corte de Contas reconheceu a necessidade de sua inserção nas discussões acerca das mudanças contábeis e, assim, designou servidores para representar o TCU e participar junto ao grupo assessor da área pública instituído pelo CFC.

Entre as discussões travadas pelo CFC, ficou estabelecido que as normas a serem convergidas não eram e não deveriam ser cópia da legislação, devendo respeitar o sistema legal, sem prejuízo de que o patrimônio seja tratado como objeto de uma ciência, pautada nos seus princípios e postulados (CFC, 2007). Com base nesse entendimento, os grupos de trabalho do CFC atuaram no sentido de elaborar as normas brasileiras (FEIJÓ; BUGARIM, 2008 , p. 80). Nesse sentido, em novembro de 2008, o CFC aprovou as primeiras Normas 
Brasileiras de Contabilidade aplicadas ao Setor Público (NBC T 16) por meio das Resoluções CFC $\mathrm{n}^{\mathrm{o}} 1.128 / 08$ a 1.137/08, alinhadas com as normas emitidas pelo IPSASB. As NBC T 16 deveriam ser observadas, obrigatoriamente, a partir de 2010.

Neste mesmo ano, o CFC instituiu uma parceria com a STN, que passou a atuar como operadora do processo de convergência. Também em 2008, foi apresentada a primeira edição do Manual de Contabilidade Aplicada ao Setor Público (MCASP), válido para o exercício de 2009 e aplicável a toda a Federação, elaborado pela STN, com o objetivo de uniformizar as conceitos e práticas contábeis, em conformidade com os documentos emitidos pelo CFC, isto é, as Orientações Estratégicas e as NBC T 16 (STN, 2016).

A Portaria STN n 467/2009, de 6 de agosto, foi a primeira a determinar os prazos de adoção obrigatória das partes do MCASP. Esses prazos sofreram várias alterações ao longo das edições do Manual (Anexo C). Foram estabelecidas datas de observância diferentes conforme os procedimentos, por exemplo, para o Plano de Contas de Contabilidade Aplicada ao Setor Público (PCASP), para as Demonstrações Contábeis Aplicadas ao Setor Público (DCASP) e os procedimentos contábeis foram segregados em patrimoniais (PCP), específicos (PCE) e orçamentários (PCO).

Além disso, vale acrescentar, que o Decreto $n^{\circ} 6.976$, de 7 de outubro de 2009, ao dispor sobre as competências do Sistema de Contabilidade Federal, definiu como um dos objetivos do referido sistema a promoção da convergência da contabilidade pública aos padrões internacionais, reforçando o papel da STN nesse processo.

Em 2010, o CFC disponibilizou a tradução das Normas Internacionais de Contabilidade Aplicadas ao Setor Público editadas pela IFAC, em uma ação conjunta com o Ibracon e a STN, na busca da adoção no Brasil de um modelo de contabilidade patrimonial, bem como da convergência das normas contábeis brasileiras às normas internacionais (CFC, 2010). Observa-se tanto em 2009 como em 2010 ações referentes à capacitação, realizadas a partir da cooperação técnica e convênios entre as organizações supracitadas.

Em fevereiro de 2011, mediante a Portaria STN n ${ }^{\circ} 111$, foi criado o grupo de Sistematização de Informações Contábeis e Fiscais - GTSIS. No final deste mesmo ano, foi emitida, por meio da Resolução CFC n ${ }^{\circ}$ 1.366/11, a décima primeira Norma Brasileira de Contabilidade Pública, a NBC T 16.11. Tal norma merece destaque por abordar o Sistema de Informação de Custos do Setor Público, já exigidos pela LRF.

Em 2012, destacam-se dois acórdãos do Tribunal de Contas da União (TCU) sobre o tema: 158/2012 e 1979/2012. O primeiro acórdão expressa o entendimento do TCU acerca da legalidade do Princípio da Competência e da mudança para o paradigma patrimonial no 
reconhecimento dos fenômenos da área pública. Nesse documento, o processo de convergência da contabilidade pública brasileira é comparado com o processo do setor privado, destacando a necessidade de alterações na lei para a normatização dos padrões contábeis em desconformidade com o previsto na Lei $\mathrm{n}^{\circ} 4.320 / 64$, e também questionando a legitimidade da emissão de normativos pela STN. Ainda, cita-se o Conselho de Gestão Fiscal previsto no artigo 67 da LRF, realçando o papel temporário da STN no que tange a edição de normas de consolidação de normas públicas. Apesar disso, o Ministro Raimundo Carneiro do TCU destaca a importância do processo de convergência e reconhece os esforços empreendidos pelo Poder Executivo e pelo CFC.

O segundo acórdão apresenta várias constatações, entre elas a fragilidade da legitimidade normativa da STN no processo de reforma da contabilidade pública no Brasil, registrando a percepção generalizada das setoriais contábeis sobre a inadequação das políticas de treinamento e a insuficiência de profissionais na contabilidade federal (TCU, 2012).

Em 2013, a Portaria STN no 634 disciplinou prazos para a adoção de procedimentos contábeis específicos, culminando na publicação, em 2015, da Portaria STN no 548, que previu prazos-limite de adoção dos procedimentos contábeis patrimoniais, trazendo em seu anexo o Plano de Implantação dos Procedimentos Contábeis Patrimoniais (PIPCP). A palavra que se destaca no documento é "gradual", depois de anos estabelecendo e prorrogando prazos, a adoção gradual é apontada como um elemento chave para a implementação das normas de contabilidade pública convergidas.

Em março de 2015, o CFC renovou o Termo de Cooperação Técnica com o IFAC com objeto de promoção, desenvolvimento e aprimoramento da profissão contábil mediante a busca de uniformização de normas internacionais. Dessa forma, destaca-se que uma das obrigações do órgão de classe é a atuação junto aos órgãos governamentais para que adotem as IPSAS.

Na Portaria $n^{\circ} 548 / 2015$, assim como na Portaria $n^{\circ}$ 634/2013, a STN utiliza como mecanismo de enforcement para a observância dos prazos estabelecidos a quitação prevista na LRF. Assim, no caso de descumprimento, o ente fica impedido de receber transferências voluntárias e contratar operações de crédito (BRASIL, 2000).

Em 2016, o Grupo Assessor da área pública divulgou um cronograma para a convergência às normas internacionais emitidas pela IFAC, cuja aprovação passou a seguir uma estratégia de cinco etapas: (i) apresentação de aspectos gerais da norma; (ii) apresentação de minuta da norma convergida; (iii) revisão e submissão à consulta pública; (iv) análise das 
contribuições; e (v) aprovação da norma pelo Grupo Assessor, com seu encaminhamento para o plenário do CFC para aprovação e publicação (CFC, 2016).

Ressalta-se que a composição do Grupo Assessor da Área Pública alterada substancialmente em 2015, de forma que o grupo passou a ter uma predominância de participantes da STN, reduzindo o número de representantes da academia. Ademais, passou a ser dividido em cinco subgrupos: (i) Governança e Articulação Institucional, com o papel de articular com órgãos de controle, Legislativo, reguladores, academia e demais entidades; (ii) Convergência, responsável por emitir as NBC TSP já convergidas às normas internacionais; (iii) Custos, para buscar o desenvolvimento conceitual e o estímulo do uso das informações de custos no governo; (iv) Disseminação, trazendo a responsabilidade de disseminar os grupos anteriores e suas ações; e (v) Práticas, como o papel de estimular trocas de experiências práticas em Contabilidade (BRASIL, 2016).

Em setembro de 2016, o CFC publicou a Norma Brasileira de Contabilidade Aplicada ao Setor Público (NBC T SP) - Estrutura Conceitual, reconhecida como a primeira norma convergida às normas internacionais, revogando a partir de janeiro de 2017 a Resolução CFC n $1.111 / 2007$, que trazia os Princípios de Contabilidade sob a Perspectiva do Setor Público, as NBC T 16.1, 16.2, 16.3, 16.4 e 16.5, e algumas partes das demais NBC T 16.

Essa ação por parte do CFC evidenciou uma intenção mais clara de adoção às IPSAS, já que as normas elaboradas anteriormente pelo órgão de classe, apesar de estarem alinhadas com as IPSAS, apresentavam uma estrutura própria e peculiar, inclusive abordando diversos aspectos não trazidos nas normas internacionais (Anexo D). No momento atual, há uma linha de trabalho que busca manter as NBC TSP o mais similar possível às IPSAS, retirando apenas os itens que realmente não são aplicáveis, tendo em vista o arcabouço brasileiro.

Em outubro de 2016, foram aprovadas as NBC TSP 01 - Receita de Transação sem Contraprestação, NBC TSP 02 - Receita de Transação com Contraprestação e NBC TSP 03 Provisões, Passivos Contingentes e Ativos Contingentes. De acordo com o CFC (2016), as novas normas já estarão inseridas na sétima edição do MCASP, válida a partir de 2017. Acrescenta-se que, diferentemente do que ocorre no setor privado, no setor público a numeração das normas convergidas não mantém relação com a numeração das normas originais.

Em suma, nota-se que no Brasil utiliza-se as IPSAS como fonte normativa para elaboração das NBC TSP, havendo, portanto, no processo de convergência brasileiro, uma certa adaptação. Na visão do CFC, a estratégia é a de "convergência integral", ou seja, as IPSAS passariam a ser traduzidas e adaptadas, sempre que necessário, à realidade do País. 
Ressalta-se que apesar de o CFC estar utilizando o termo "convergência integral", nesse primeiro momento, se nota mais uma adoção das IPSAS no país, revestidas sob a nomenclatura de normas brasileiras (NBC T SP). Assim, conforme apontado por Nobes e Parker (2008, p. 75), nota-se que no país que alguns termos se tornaram quase termos técnicos e têm sido utilizados como sinônimos, mas possuem diferenças entre si.

Quanto ao papel da STN, sua atuação é no sentido de subsidiar a operacionalização das normas emitidas pelo CFC, especialmente, mediante a publicação do MCASP, que traz normas de consolidação das contas da federação e busca basear-se nas NBC T SP facilitando a sua implementação. A Figura 7 esclarece a ordem de observância dos normativos de contabilidade pública no Brasil. A Figura 7 esclarece a ordem de observância dos normativos de contabilidade pública no Brasil.

Figura 7 - Ordem de observância dos normativos de Contabilidade Pública no Brasil.

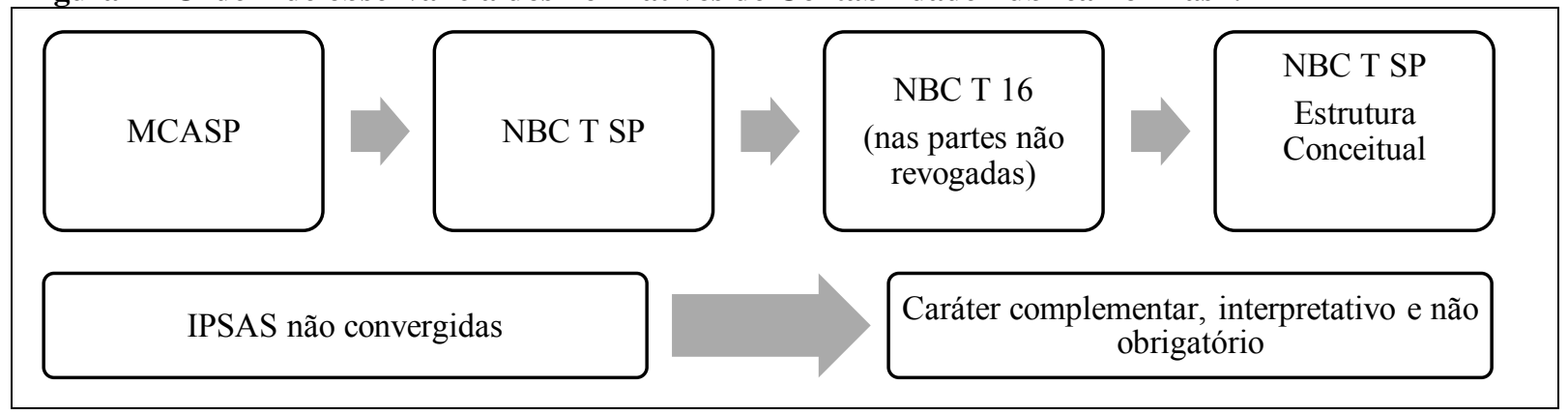

Fonte: STN, 2016.

Registre-se que está prevista a aprovação de mais duas normas até o fïm do exercício de 2016. Para os anos para os anos de 2019 a 2021, está prevista a convergência de mais 12 NBC T SP. A nona edição do MCASP, prevista para julho de 2021 e válida a partir de 2022, deve abranger as dezesseis NBC T SP restantes (BRASIL, 2016).

Cabe acrescentar ainda o Projeto de Lei Complementar PLP n ${ }^{\circ}$ 295/2016, que visa regulamentar o disposto no art. $165, \S 9^{\circ}$, da Constituição Federal, que prevê a criação de lei complementar para "dispor sobre o exercício financeiro, a vigência, os prazos, a elaboração e a organização do plano plurianual, da lei de diretrizes orçamentárias e da lei orçamentária anual", além de estabelecer normas de gestão financeira e patrimonial.

Em sua parte principal, o projeto, que se encontra em tramitação, substitui a Lei $\mathrm{n}^{\circ}$ 4.320/64, um dos marcos da contabilidade pública brasileira. Segundo o autor da proposta, o Senador Tasso Jereissati, o objetivo é reforçar a responsabilidade na gestão das finanças públicas, o que inclui tanto os processos de planejamento e orçamento, como o de gestão financeira, contábil e patrimonial. No que se refere especificamente à contabilidade, caso aprovado, a convergência passará a constar em lei, reforçando a reforma da contabilidade 
pública: “[...] as normas específicas editadas pelo órgão central de contabilidade do Poder Executivo federal, as quais buscarão, subsidiariamente, a convergência às normas brasileiras de contabilidade e aos padrões internacionais de contabilidade do setor público [...]" (BRASIL, 2016).

Diante do exposto, a Figura 8 apresenta na ordem cronológica alguns dos principais normativos necessários para compreender o processo de convergência da contabilidade pública às normas internacionais no Brasil. 
Figura 8 - Linha Temporal dos Principais Normativos da Contabilidade Pública Brasileira e do Processo de Convergência às Normas Internacionais

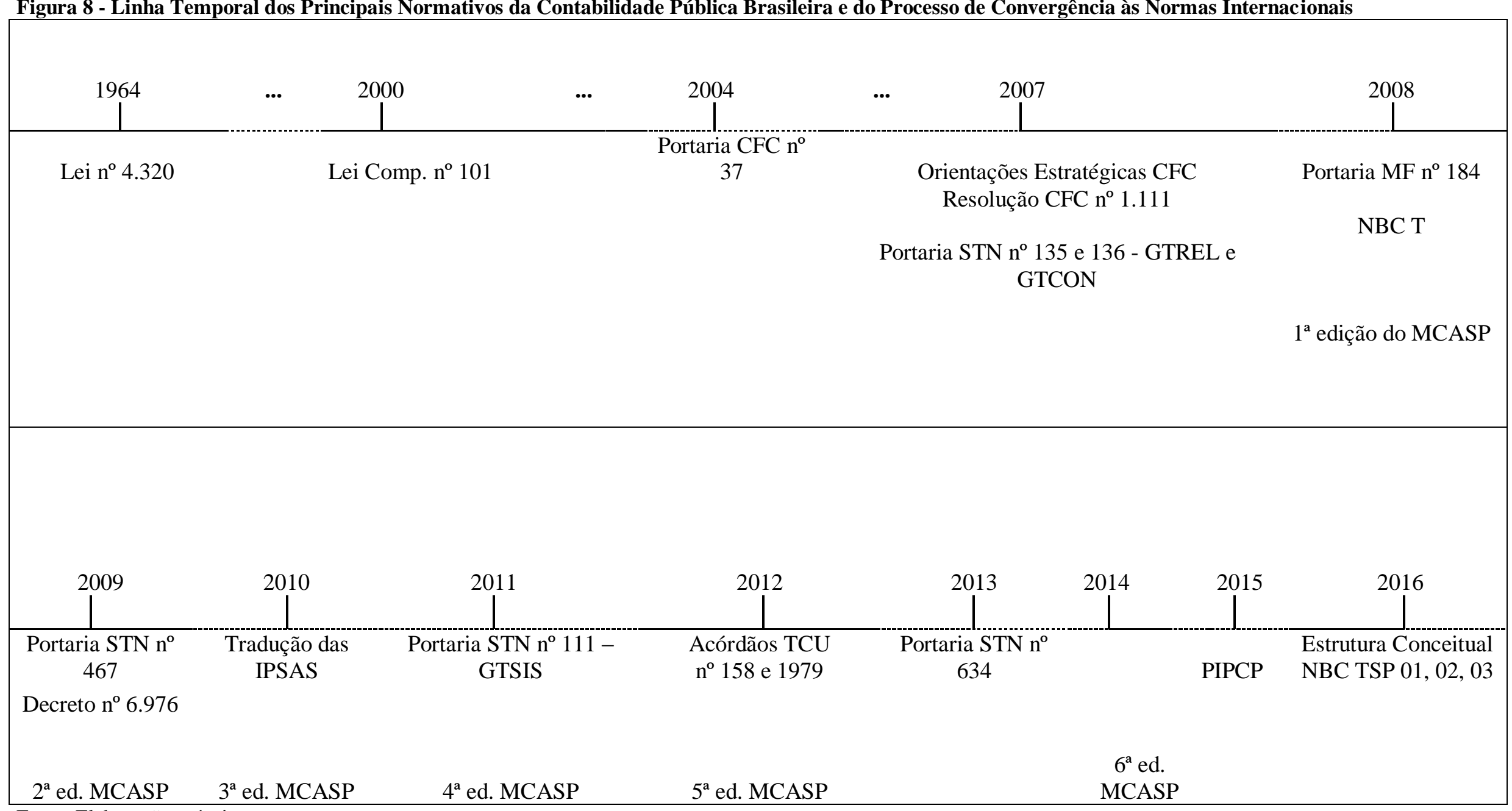




\subsection{ATORES ENVOLVIDOS}

$\mathrm{Na}$ literatura internacional, destaca-se a influência das instituições financeiras internacionais ao recomendar para diversos países a convergência aos padrões internacionais emitidos pelo IPSASB. E a nível nacional, pode-se afirmar que cada país tem seus atoreschave na condução e implementação das IPSAS: enquanto em alguns se tem a figura de Comitês de Convergência, em outros o Tribunal de Contas assume papel determinante (BRUSCA; MONTESINOS; CHOW, 2013; IFAC, 2013). A participação dos atores no processo é ponto fundamental para a adequada implementação das mudanças desejadas. (GAMA; DUQUE; ALMEIDA, 2014).

Mapurunga, Meneses e Peter (2011) esclarecem que no contexto brasileiro o processo de convergência brasileiro tem sido conduzido pelo esforço mútuo de diversos atores: CFC, STN, Tribunais de Contas, Instituições de Ensino Superior e representantes das esferas Federal, Estadual e Municipal.

O CFC, órgão de classe profissional contábil no Brasil, foi criado em 1946, por meio do Decreto-Lei $n^{\circ}$ 9.295, com a finalidade de orientar, normatizar e fiscalizar o exercício da profissão contábil, e tem atuado na edição das Normas Brasileiras de Contabilidade de natureza técnica e profissional. Especificamente quanto à edição de normas, o CFC criou em 2004 um grupo de trabalho no intuito de elaborar as Normas Brasileiras de Contabilidade Aplicadas ao Setor Público (NBCASP), integrado por professores universitários e por membros do CFC, da STN e dos Tribunais de Contas (TCs).

Já a STN, criada em março de 1986 mediante o Decreto ${ }^{\circ}$ 92.452, pertence à estrutura do Ministério da Fazenda e é o órgão central do Sistema de Administração Financeira Federal e do Sistema de Contabilidade Federal do Brasil. Como órgão central desses sistemas, tem uma série de competências enumeradas na Lei 10.180/01. Entre essas competências, destacam-se: a edição de normas sobre a programação financeira e a execução orçamentária e financeira, bem como o acompanhamento, a sistematização e a padronização da execução da despesa pública; a manutenção e aprimoramento o Plano de Contas; o estabelecimento de normas e procedimentos para o adequado registro contábil dos atos e dos fatos da gestão orçamentária, financeira e patrimonial nos órgãos e nas entidades da Administração Pública Federal (BRASIL, 2001). Ademais, nos termos da LRF, enquanto não for criado o Conselho Fiscal, cabe à STN a edição de normas gerais para consolidação das contas públicas.

No que tange o papel do TCU, deve-se considerar a Declaração de Lima da International Organisation of Supreme Audit Institutions (INTOSAI). Segundo tal 
documento, considerado a carta magna da auditoria governamental, é recomendável que os regulamentos que visam estabelecer procedimentos de contabilidade sejam elaborados de acordo com a orientação da Entidade de Fiscalização Superior (EFS) (INTOSAI, 2016). Portanto, o Tribunal de Contas da União deve se inserir nas discussões de mudanças na normatização contábil, tendo em vista o impacto tanto na gestão, no controle e na transparência do setor público.

Ressalta-se ainda que cabe ao TCU emitir Parecer Prévio sobre contas prestadas anualmente pelo Presidente da República, de forma a avaliar e se pronunciar acerca das informações do Balanço-Geral da União (BGU) e informações contábeis consolidadas do Setor Público Federal (BRASIL, 1988). Dessa forma, o TCU possui um papel relevante para a transparência na Administração Pública, tendo em vista que a confiabilidade das informações dependem da realização de auditorias contábeis.

Cabe ainda acrescentar o papel do Ministério da Transparência, Fiscalização e Controle, órgão central do sistema de controle interno do Poder Executivo, que, além de também atuar nas fiscalizações contábeis, deve apoiar o controle externo no exercício de sua missão institucional.

Apesar dessa diversidade de atores, pesquisadores como Vicente, Morais e Platt Neto (2012) trazem, contudo, que o processo brasileiro tem sido basicamente conduzido pelo CFC e pela STN. Herbest (2010) compartilha de posicionamento similar quanto aos promotores da reforma no Brasil. Segundo Fragoso et al. (2012), há uma escassez na literatura nacional de pesquisas que tratem a convergência das normas de contabilidade do setor público, apesar desse fator, os estudos que abordam o tema citam na maior parte dos casos os referidos atores: STN e CFC.

Cabe acrescentar, ainda, que o Comitê Gestor da Convergência, criado pela Resolução CFC $\mathrm{n}^{\circ} 1.103 / 07$, tem como objetivo identificar e monitorar as ações a serem implantadas para viabilizar a convergência das Normas Contábeis e de auditoria, a partir das Normas Brasileiras de Contabilidade editadas pelo CFC, dos Pronunciamentos de Contabilidade e Auditoria editados pelo Comitê de Pronunciamentos Contábeis (CPC) e IBRACON, respectivamente, bem como de assuntos regulatórios no Brasil, visando o alinhamento às Normas Internacionais de Auditoria e Asseguração emitidas pela IFAC e às melhores práticas internacionais em matéria regulatória, segundo informações disponíveis no site do CFC. Na prática, contudo, não há muita clareza no papel que tem exercido, quando apresentado na bibliografia brasileira, menciona-se basicamente a sua criação. 
Do ponto de vista institucional, há que destacar também a criação de três grupos de trabalho pela STN: o Grupo Técnico de Padronização de Procedimentos Contábeis (GTCON), o Grupo Técnico de Padronização de Relatórios (GTREL) e o Grupo de Sistematização de Informações Contábeis e Fiscais (GTSIS), que atuam no âmbito da União, Estados, Distrito Federal e Municípios.

O GTCON é o grupo técnico responsável pela análise e pela elaboração de diagnósticos e estudos visando à padronização mínima de conceitos e práticas contábeis, plano de contas e classificação orçamentária de receitas e despesas. Já ao GTREL cabe a elaboração de análises, diagnósticos e estudos, visando à promoção, à harmonização e à padronização de relatórios e demonstrativos, destacadamente os previstos pela Constituição Federal e pela Lei Complementar nº 101/2000. Com relação ao GTSIS, sua função é analisar e elaborar diagnósticos e estudos visando à harmonização das regras e funcionalidades dos sistemas contábeis e fiscais.

Os três grupos têm caráter técnico e consultivo e são compostos por membros representantes de cada ente federativo, representantes de órgãos de controle interno e externo, do CFC, entre outros. A Composição dos referidos grupos é apresentada no Quadro 2.

Quadro 2 - Composição do GTCON, GTREL e GTSIS

\begin{tabular}{|c|c|c|c|}
\hline Participantes & GTCON & GTREL & GTSIS \\
\hline Associação Brasileira das Secretarias de Finanças das Capitais (ABRASF) & $\mathrm{X}$ & $\mathrm{X}$ & $\mathrm{X}$ \\
\hline Associação Brasileira de Municípios (ABM) & $\mathrm{X}$ & $\mathrm{X}$ & $\mathrm{X}$ \\
\hline Associação dos Membros dos Tribunais de Contas do Brasil (ATRICON) & $\mathrm{X}$ & $\mathrm{X}$ & $\mathrm{X}$ \\
\hline Confederação Nacional dos Municípios (CNM) & $\mathrm{X}$ & $\mathrm{X}$ & $\mathrm{X}$ \\
\hline Conselho da Justiça Federal (CJF) & & $\mathrm{X}$ & $\mathrm{X}$ \\
\hline Conselho Federal de Contabilidade (CFC) & $\mathrm{X}$ & $\mathrm{X}$ & \\
\hline Conselho Nacional de Controle Interno (CONACI) & $\mathrm{X}$ & $\mathrm{X}$ & $\mathrm{X}$ \\
\hline Conselho Nacional de Justiça (CNJ) & & $\mathrm{X}$ & $\mathrm{X}$ \\
\hline $\begin{array}{l}\text { Conselho Nacional de Secretários Estaduais do Planejamento } \\
\text { (CONSEPLAN) }\end{array}$ & & $\mathrm{X}$ & \\
\hline Conselho Nacional do Ministério Público (CNMP) & & $\mathrm{X}$ & \\
\hline $\begin{array}{l}\text { Consultoria de Orçamento e Fiscalização Financeira da Câmara dos } \\
\text { Deputados (CONOF) }\end{array}$ & $\mathrm{X}$ & $\mathrm{X}$ & \\
\hline Consultoria de Orçamento, Fiscalização e Controle, do Senado (CONORF) & $\mathrm{X}$ & $\mathrm{X}$ & $\mathrm{X}$ \\
\hline Controladoria-Geral da União (CGU) & $\mathrm{X}$ & $\mathrm{X}$ & \\
\hline Departamento de Economia da Saúde e Desenvolvimento (DESD) & & $\mathrm{X}$ & \\
\hline Departamento dos Regimes de Previdência no Serviço Público (DRPSP) & $\mathrm{X}$ & $\mathrm{X}$ & \\
\hline Frente Nacional de Prefeitos (FNP) & $\mathrm{X}$ & $\mathrm{X}$ & \\
\hline Fundo Nacional de Desenvolvimento da Educação (FNDE) & & $\mathrm{X}$ & \\
\hline Grupo dos Gestores de Finanças Estaduais (GEFIN) & $\mathrm{X}$ & $\mathrm{X}$ & $\mathrm{X}$ \\
\hline Instituto Brasileiro de Geografia e Estatística (IBGE) & $\mathrm{X}$ & $\mathrm{X}$ & \\
\hline Instituto Rui Barbosa (IRB) & $\mathrm{X}$ & $\mathrm{X}$ & $\mathrm{X}$ \\
\hline Ministério Público Federal (MPF) & & $\mathrm{X}$ & $\mathrm{X}$ \\
\hline Secretaria de Orçamento Federal (SOF) & $\mathrm{X}$ & $\mathrm{X}$ & \\
\hline Tribunal de Contas da União (TCU) & $\mathrm{X}$ & $\mathrm{X}$ & \\
\hline
\end{tabular}

Fonte: Adaptado de Lino (2015). 
A constituição do GTCON foi relevante para a consolidação de um ambiente de debates envolvendo profissionais que atuam nas três esferas de poder e área e para a aproximação dos Tribunais de Contas aos debates prévios do processo contábil, que não era usual (NEVES, 2014). Feijó e Ribeiro (2014) destacam a importância do GTCON, especialmente mediante a "teoria do pertencimento", ressaltando a contabilidade como ciência social e os desafios que isso traz numa mudança de cultura, de forma que todos os atores devem contribuir de forma ativa para que sintam partem do processo de mudança. Além disso, segundo os pesquisadores, a criação do referido grupo foi motivada pela busca de maior contribuição, saindo do âmbito apenas da STN, pelo incentivo ao processo criativo e convicção de que há menos questionamentos quando as decisões são democráticas, permitindo que as publicações sejam de fato aplicáveis.

Periodicamente, a STN realiza reuniões com esses grupos técnicos de trabalhos para implementar ações visando a continuidade do processo de convergência. Contudo, apesar da participação de outros órgãos, a revisão da literatura evidencia como principais atores envolvidos no processo o CFC e a STN, destacando-se a relevância de participação do Tribunal de Contas da União, no incentivo e controle da reforma da contabilidade pública.

\subsection{A TRAJETÓRIA DOS PRINCIPAIS ATORES E A PROMOÇÃO E DIRECIONAMENTO DO PROCESSO DE CONVERGÊNCIA}

Aborda-se na trajetória dos atores a motivação de sua atuação no processo, o papel que vem sendo realizado, bem como as ações realizadas e dificuldades observadas na concretização dessas, e os resultados obtidos e esperados.

\subsubsection{Trajetória do CFC}

$\mathrm{Na}$ perspectiva do membro do Grupo Assessor do CFC entrevistado, havia certa insatisfação dos contadores em relação ao próprio órgão de classe devido à falta de espaço da área pública no CFC. Entendia-se que havia necessidade de aprimoramento de aspectos tratados pela Lei $\mathrm{n}^{\circ} 4.320 / 64$ e de uma maior aproximação da contabilidade pública aos aspectos científicos da contabilidade como ciência. Nesse sentido, o grupo foi segregado em duas frentes de trabalho: uma para propor alterações à lei de finanças públicas e o outra para desenvolver um arcabouço conceitual a nível de normas brasileiras de contabilidade. O que resultou na interpretação dos Princípios Contábeis ao setor público e na elaboração das primeiras dez primeiras NBCT 16. 
$\mathrm{Na}$ visão do entrevistado em nome do CFC, observa-se que os grupos iniciais de contabilidade pública surgiram por uma questão interna relacionada ao aperfeiçoamento por parte dos próprios contadores, especialmente numa busca de critérios mais objetivos e de evidenciação clara dos ativos e passivos públicos. No entanto, a questão da convergência, propriamente dita, também foi impactada por fatores externos, como a exigência de transparência em relação ao endividamento público e critérios mais objetivos e de evidenciação dos ativos e passivos públicos. O entrevistado entende que o processo de convergência foi apressado devido à bolha imobiliária dos Estados Unidos da América (EUA), que teve consequências a níveis sistêmicos, e também a crise ocorrida na Grécia, onde o endividamento se tornou incompatível com capacidade de pagamento do País, levantando questões relacionadas à melhoria das informações contábeis.

Quanto às ações implementadas pelo CFC, o entrevistado destaca a relevância de elaboração e publicação das Normas Brasileiras de Contabilidade (NBC T 16). Considerando o estágio em que se encontrava a contabilidade, o entrevistado do CFC, acredita que o processo já mostra resultados positivos, tendo em vista que grande parte dos Estados e Municípios já seguem as orientações emitidas pelo CFC, além da evolução na divulgação do patrimônio, especialmente com as mudanças da forma de evidenciação e nas demonstrações contábeis exigidas. De forma geral, o entrevistado aponta como resultado esperado do processo de convergência a melhor evidenciação e controle do patrimônio público, ressaltando que o tempo que irá levar para a conclusão do processo dependerá da sociedade e de como o órgão vai exigir as mudanças para as demais instituições públicas.

Do ponto de vista do entrevistado do CFC, no que tange ao papel normativo do Conselho, o órgão tem mostrado avanços, especialmente a partir na elaboração das normas brasileiras de contabilidade públicas, no entanto, quanto ao papel de fiscalização, parece que até o momento não foi tão exercido, tento em vista que houve falha na fiscalização da aplicação das referidas normas.

Quanto ao planejamento da implementação das normas, apontou-se que os cronogramas de adoção obrigatória emitidos pela STN foram acordados com o CFC, e tinhase uma vontade de que o processo fosse rápido. No entanto, a dificuldade enfrentada pelos entes federados no processo de adoção das normas levou a Confederação Nacional de Municípios (CNM), através de seus representantes nos grupos de trabalho da STN, a pressionar por uma agenda diferenciada dependendo do porte do Município.

Sobre a mudança de composição do grupo assessor em 2015, de acordo com o entrevistado do CFC, foi acompanhada de uma mudança no entendimento do grupo que 
passou a ser mais voltado para um processo de adoção das normas internacionais, sendo que para ele, uma possível justificativa seria o convênio do CFC firmado com a IFAC, em que se falava em adoção das normas.

Em relação às dificuldades observadas na implementação, o entrevistado do CFC afirma a falta de sistema e pessoal qualificado para atuar no setor público. Ademais, quanto às ações de formação de multiplicadores, foram encontradas algumas dificuldades adicionais na medida em que alguns dos profissionais que foram capacitados para atuar com a disseminação do conhecimento se apropriaram desse e passaram a vender no mercado, através de cursos pagos e congêneres. O entrevistado também cita o problema da dimensão do Brasil, de forma que não há profissionais suficientes para atender a demanda do país.

Diante desse cenário, o entrevistado do CFC ressalta a importância do papel colaborativo dos atores para a implementação das normas de contabilidade pública, não só no âmbito do CFC e STN, mas também dos TCs, tendo em vista a necessidade de aprimoramento das ações de fiscalização.

\subsubsection{Trajetória da STN}

Na visão do entrevistado da STN, uma motivação importante para o início do processo de convergência da contabilidade pública brasileira foi a necessidade de migrar para o novo padrão de finanças públicas, em que seria necessária uma contabilidade por competência. Mas também havia uma necessidade de aperfeiçoamento das normas nacionais, então, o processo surgiu muito mais do corpo técnico do que do corpo político. Como o padrão internacional tem sido adotado por diversos outros países, a escolha das IPSAS era vista, na visão do entrevistado, como "o processo mais natural".

Em relação às ações implementadas, menciona-se o MCASP e as capacitações realizadas. Segundo o entrevistado, os resultados obtidos com essas ações realizadas são difíceis de se avaliar, no entanto, as ações de capacitação têm possibilitado uma melhoria na transparência das contas públicas. Ademais, é citada a Avaliação da Transparência Fiscal, realizada pelo FMI, em junho de 2016, que relata a implementação das normas baseadas nas IPSAS como uma iniciativa na busca de melhoria da transparência e confiabilidade das informações, sendo que essa implementação tem contribuído para a produção de demonstrações contábeis mais abrangentes.

De acordo com o entrevistado, espera-se que ao fim do processo de convergência possa-se atingir um maior grau de transparência, possibilitando identificar o grau de 
comprometimento de gerações futuras, desconstruir um pouco dos ciclos políticos e, de maneira geral, uma melhor gestão das finanças públicas.

As principais dificuldades apontadas pelo entrevistado da STN para a concretização das ações planejadas foram o descrédito do processo, a falta de envolvimento dos gestores públicos, que demonstram certa resistência, a falta de planejamento inicial e, por fim, a complexidade da federação brasileira.

Ao ser questionado acerca dos cronogramas de implementação, o entrevistado da STN menciona a falta de conhecimento dos próprios envolvidos e, inclusive, da dimensão do processo e do que seria enfrentado pela frente. Então, a ideia inicial era estabelecer prazos para forçar a preparação, o que de certa forma, segundo o entrevistado da STN, foi importante porque alguns atores já começaram a se preparar e implementar ações necessárias para a convergência da contabilidade pública aos padrões internacionais.

\subsubsection{Trajetória do TCU}

De acordo com o entrevistado do TCU, não houve muitas pressões externas para a adoção das IPSAS, sendo que, em sua percepção, a escolha dessa norma como referência para o processo de convergência ocorreu devido a uma decisão do CFC. Em seu entendimento, havia uma ideia compartilhada pelo órgão de classe e pelo órgão central de contabilidade de que seria interessante seguir o movimento que estava ocorrendo internacionalmente.

O entrevistado relatou que o TCU foi convidado a participar dos Grupos do CFC após a elaboração das NBC T 16, e que, em algum momento, no próprio grupo começou-se a questionar a adoção das IPSAS, se realmente seria o melhor padrão a ser seguido. Mas, devido a outros compromissos, o entrevistado passou a não mais participar das reuniões e, para ele, não se sabe ao certo a mudança que se teve no Grupo após o levantamento de tal questionamento.

Segundo o entrevistado do TCU, a contribuição direta feita pela Corte de Contas foi pequena, basicamente limitando-se às ações fiscalizatórias que resultaram nos Acórdãos $\mathrm{n}^{\circ}$ 158/12 e n 1979/12, não podendo ele afirmar acerca dos resultados das ações realizadas, nem sobre a existência ou não de um planejamento de ações para cooperação com o processo de convergência da contabilidade pública. 


\subsubsection{Promoção e Direcionamento do Processo de Convergência}

Diante do que foi relatado nas entrevistas, conclui-se que no início do processo não se tinha um planejamento bem definido, marcado pela ausência de ações planejadas a médio e longo prazo.

De 2010 a 2014, a visão que se tem é que houve um esfriamento do processo de convergência no Brasil, e nota-se a ausência de fiscalização da implantação das normas que se relacionam com os poucos resultados práticos na maior parte dos entes federativos subnacionais. Nesse sentido, ressalta-se que mecanismos de enforcement constituem um fator essencial no processo de convergência (GUERREIRO, 2009). No período de 2010 a 2012, verificam-se ações relacionadas à capacitação, no entanto, nos anos seguintes, tal número foi reduzido substancialmente.

No ano de 2015, o processo mostra sinais de avanço quanto ao planejamento e transparência das informações, já que se nota uma maior divulgação das ações e dos planos de trabalho que vêm sendo elaborados. Com a publicação do Plano de Implantação de Procedimentos Contábeis Patrimoniais (PIPCP) passa a ser estabelecido um nível maior de detalhamento em relação aos prazos apresentados anteriormente, trazendo, também, prazos diferenciados para Municípios de pequeno porte. $O$ que pode colaborar para a institucionalização das novas práticas contábeis, ao deixar mais claro as ações a serem realizadas e estabilizar as expectativas.

Outro destaque quanto a esse cronograma é que, segundo entrevistado da STN, contou com a participação de outros atores. Por exemplo, foi discutido com o Grupo de Finanças Estaduais (GFIN), que opinou por datas que julgavam ser viáveis. Além disso, o entrevistado afirmou que o documento foi elaborado em consonância com as estratégias elaboradas pelo CFC, de forma a conciliar os prazos de elaboração das próximas normas e, por fim, o documento também foi submetido a consulta pública.

Visando a triangulação dos dados, a visão dos entrevistados do CFC, STN e TCU foi confrontada com a visão de outros envolvidos, captada mediante aplicação de questionário (APÊNDICE C).

Assim, quanto ao perfil dos respondentes, houve predominância do sexo masculino (62\%) e na faixa etária de 46 a 55 anos. A maioria (94\%) trabalha na área pública, sendo que desses, 54\% atuam na esfera Estadual, 29\% na esfera Municipal e 17\% na Federal. Dos que atuam na área pública, quanto à esfera de Poder, 56\% trabalham no Executivo, 36\% em Tribunais de Contas, $5 \%$ no Judiciário e 3\% no Legislativo. O tempo médio de atuação no setor público era de 15 anos, e de 11 anos de experiência com a contabilidade aplicada ao 
setor público. Ainda, $48 \%$ dos respondentes participaram em três ou mais anos nas reuniões do GTCON.

Quanto à motivação para o processo de convergência, as palavras que mais se destacaram foram: "internacionais", "padronização", "comparabilidade" e "transparência". A palavra "internacionais" foi bastante utilizada no contexto de necessidade de adequação a padrões internacionais e a exigências de organismos internacionais. Nesse sentido, as respostas demonstram uma visão das IPSAS como um benchmarking a ser seguido, um padrão que pode proporcionar maior transparência. As respostam abordaram a questão de melhoria da visão externa acerca do País, bem como o aumento da credibilidade, no intuito de captar investimentos e facilitar relações de negócios.

Assim, a melhoria na transparência pública foi muitas vezes relacionada com a questão de credibilidade externa. Apesar de provedores de recursos serem considerados como usuários primários dos Relatórios Contábeis de Propósito Geral das Entidades do Setor Público (RCPGs), eles são trazidos nas normas internacionais e na NBC T SP - EC após os usuários de serviços públicos, indicando que estes últimos seriam o foco primário das RCPGs. No entanto, observou-se que nas repostas acerca da motivação, o aumento da transparência só foi relacionado aos cidadãos uma vez.

Quanto aos resultados e efeitos observáveis até o momento, o que mais se destacou foi a padronização, o patrimônio e a transparência. Além disso, alguns respondentes apontaram uma percepção de valorização do contador.

Em relação às dificuldades apontadas nos questionários, essas foram analisadas com base nas barreiras delineadas no estudo de Ouda (2008, p. 114). A falta de pessoal qualificado, a estrutura do país e a falta de pressão externa foram as barreiras mais citadas. Assim, a quantidade de contadores atuando no setor público, o sistema de treinamento, a extensão do país e a sua estrutura (com uma diferença cultura e econômica entre os entes, especialmente os municípios) e a falta de demanda de informação melhorada pelos decisores têm sido barreiras na implantação das normas contábeis.

O FMI ao tratar sobre a preparação da transição para a contabilidade por competência, aponta o apoio político e a liderança técnica como pré-requisitos para a reforma (CAVANAGH; FLYNN; MORETTI, 2016). Nesse sentido, a maior parte $(41,94 \%)$ dos demais envolvidos no processo acreditam que tal apoio foi médio, mas como o ranking médio obtido foi inferior a 3, pode-se afirmar que o apoio político e a liderança técnica ainda são baixos. A interação dos atores é considerada média pela maioria dos respondentes, mas seu ranking médio apresenta-se acima de 3 evidenciando que de maneira geral a interação ocorre. 
Obtém-se posicionamento similar quanto a adequação do processo como um todo, mostrando concordância com a forma que tem sido conduzido. A relação de custo e benefício do processo e a transparência na sua condução são considerados pela maior parte dos respondentes como alto, sendo que esta última apresenta o maior ranking médio das questões listadas.

Tabela 1 - Grau de Percepção acerca do Processo de Convergência da Contabilidade Pública Brasileira

\begin{tabular}{|c|c|c|c|c|c|c|}
\hline Questão & $\begin{array}{c}\text { Muito } \\
\text { Baixo }\end{array}$ & Baixo & Médio & Alto & $\begin{array}{c}\text { Muito } \\
\text { Alto }\end{array}$ & RM \\
\hline Apoio político e liderança técnica & $14,52 \%$ & $30,65 \%$ & $41,94 \%$ & $8,06 \%$ & $4,84 \%$ & 2,58 \\
\hline $\begin{array}{c}\text { Interação entre os atores promotores e } \\
\text { direcionadores envolvidos no processo de } \\
\text { convergência da contabilidade pública brasileira }\end{array}$ & $14,29 \%$ & $30,16 \%$ & $41,27 \%$ & $7,94 \%$ & $4,76 \%$ & 3,35 \\
\hline $\begin{array}{c}\text { Planejamento do processo de convergência e sua } \\
\text { implementação no país }\end{array}$ & $3,17 \%$ & $6,35 \%$ & $46,03 \%$ & $41,27 \%$ & $3,17 \%$ & 3,35 \\
\hline $\begin{array}{c}\text { Transparência na condução do processo de } \\
\text { convergência }\end{array}$ & $0,00 \%$ & $7,94 \%$ & $33,33 \%$ & $52,38 \%$ & $6,35 \%$ & 3,57 \\
\hline $\begin{array}{c}\text { Relação de Custo versus Benefício do processo } \\
\text { de convergência }\end{array}$ & $6,35 \%$ & $7,94 \%$ & $36,51 \%$ & $44,44 \%$ & $4,76 \%$ & 3,33 \\
\hline $\begin{array}{c}\text { Adequação do processo de convergência, como } \\
\text { um todo, considerando o cenário do país } \\
\text { (Decisão de adoção ou harmonização, forma } \\
\text { como tem sido conduzido, etc.) }\end{array}$ & $1,61 \%$ & $9,68 \%$ & $46,77 \%$ & $33,87 \%$ & $8,06 \%$ & 3,37 \\
\hline
\end{tabular}

Fonte: Elaboração própria.

Ademais, nos questionários nota-se que maioria dos respondentes concorda com a necessidade de mudanças das normas, notando a importância do processo de convergência às normas internacionais. Ao analisar as apresentações disponibilizadas na internet sobre o processo de convergência, realizadas pela STN, observa-se que grande parte do foco nos primeiros anos do processo de reforma foi na conscientização da necessidade da reforma da contabilidade pública, enfatizando quase sempre os benefícios que as IPSAS poderiam proporcionar. Diante disso, e considerando que $44 \%$ dos respondentes participaram de mais de 15 cursos, palestras e capacitações sobre a Contabilidade Aplicada ao Setor Público, desde de 2007, pode-se afirmar que as ações realizadas podem ter contribuído para a redução de resistência ao processo.

Assim, diferentemente do que ocorreu na Finlândia (OULASVIRTA, 2014) e na Rússia (ANTIPOVA; BOURMISTRO, 2013), no Brasil os contadores reconhecem a importância da mudança. No entanto, parece que essa visão não é compartilhada pelos gestores, tendo em vista que a falta de reconhecimento e apoio desses na implementação das normas foi frequentemente apontada nos questionários como dificuldades encontradas no processo. 
Em suma, considerando a trajetória e a percepção dos principais atores envolvidos, pode-se dizer que os estímulos para a atuação dos atores na reforma da contabilidade pública foram diferentes, enquanto o CFC passou a abordar o assunto por pressões normativas relacionadas a demandas da própria profissão contábil, a motivação da STN pareceu estar mais relacionada com a necessidade de padronização e consolidação das contas públicas, sendo influenciada pelas demandas da FMI quanto à elaboração das estatísticas fiscais.

Embora a própria STN não tenha estimado os custos e os benefícios da reforma, há uma percepção geral de que a relação de custo-benefício do processo de convergência é boa. A razão de tal percepção pode estar relacionada a fatores de legitimidade e isomorfismo a nível mundial, pois conforme Adhikari e Gårseth-Nesbakk (2016) retratam, parte da literatura aponta que a adoção está mais relacionada a questões de legitimidade do que de eficiência.

Quanto ao planejamento do processo de implementação das normas convergidas, observa-se que não houve um planejamento bem claro que definisse a estratégia de implementação das normas convergidas até o ano de 2015. No entanto, pode-se observar, a partir das respostas obtidas, que o CFC e a STN têm interagido desde o início, participando em conjunto das decisões na condução do processo. Contudo, há a necessidade de envolvimento de outros atores para que a implementação seja bem-sucedida.

Nesse sentido, ressalta-se que o envolvimento político no processo de convergência não foi muito abordado, indicando que ainda é baixo. Segundo Oulasvirta (2014, p. 275), normalmente os políticos apoiam as IPSAS por buscar legitimidade e uma aparência de modernidade e eficácia aos olhos do público, no entanto, como não foi notado um alto envolvimento, infere-se que o Poder Legislativo e os cidadãos do Brasil ainda se mostram pouco exigentes acerca da accountability (REVOREDO, 2008).

\subsection{A INFLUÊNCIA DOS ATORES ENVOLVIDOS}

Nos primeiros anos do processo de convergência, notou-se uma atuação mais influente por parte do CFC, com ações de apoio da STN. O órgão de classe emitiu verdadeiros marcos na contabilidade pública brasileira, como a aplicação dos Princípios Contábeis sob a Perspectiva do Setor Público e as Orientações Estratégicas para o desenvolvimento conceitual e para o fortalecimento institucional da Ciência Contábil.

A partir de 2008, observa-se que a STN passou a assumir um papel mais predominante, emitindo os MCASPs, Orientações Técnicas, Instruções de Procedimentos Contábeis (IPCs) e outros normativos relevantes para o andamento do processo de 
convergência às normas internacionais. Acrescenta-se que as IPCs são emissões de caráter orientador e de observância facultativa com vistas a auxiliar os entes na aplicação e interpretação das normas. Já as notas técnicas têm o objetivo de esclarecer normativos ou outras questões encontradas no caso concreto.

Destaca-se que ainda que as pesquisas realizadas no site institucional da STN mostram que o órgão disponibiliza uma série de apresentações, apostilas, vídeo aulas e cursos de multiplicadores com vistas a capacitar disseminar os conhecimentos relativos à contabilidade aplicada ao Setor Público. Além disso, ações de alinhamento técnico e pedagógico, com vistas a formação de multiplicadores, têm sido desenvolvidas principalmente em parceria com o CFC.

Muitos eventos também passaram a ser realizados, como a Semana Contábil e Fiscal para Estados e Municípios (SECOFEM) e o Seminário Brasileiro de Contabilidade Aplicada ao Setor Público (SBCASP). Ressalta-se que grande parte os eventos realizados foram objetos de acordo de cooperação técnica com o CFC, e que maioria dos eventos e cursos oferecidos, de maneira geral, conta com a participação de palestrantes da STN.

Quanto às ações de capacitação, observa-se no quadro a seguir a predominância e ações conjuntas, especialmente do CFC e STN. Cabe destacar que o Quadro 3 foi elaborado a partir das informações obtidas pela STN, via e-SIC. O mesmo pedido foi feito ao CFC, no entanto, o órgão não informou ao certo as ações de capacitações realizadas (APÊNDICE D).

Quadro 3 - Ações de Capacitação realizados desde 2010 e atores envolvidos

\begin{tabular}{|c|c|c|c|c|c|c|c|}
\hline & & & & En & olvidos & & \\
\hline Cursos e capacitações & Período & STN & CFC & ESAF & TCES & TCMs & Outros \\
\hline Curso Básico do MCASP & $\operatorname{mar} / 10$ & $\mathrm{X}$ & & & & & \\
\hline Curso Básico do MCASP & mai/10 & $X$ & & & & & \\
\hline Curso Básico do MCASP & ago/10 & $X$ & & & & & \\
\hline Curso Avançado do MCASP & mai/10 & $\mathrm{X}$ & & & & & \\
\hline Curso Avançado do MCASP & ago/10 & $X$ & & & & & \\
\hline $\begin{array}{l}\text { Curso de Contabilidade Aplicada ao Setor } \\
\text { Público Multiplicadores - NACIONAL }\end{array}$ & out $/ 10$ & $\mathrm{X}$ & & $X$ & & & $\mathrm{X}$ \\
\hline $\begin{array}{l}\text { Curso de Contabilidade Aplicada ao Setor } \\
\text { Público Multiplicadores - PR }\end{array}$ & nov/11 & $\mathrm{X}$ & & & $\mathrm{X}$ & & $\mathrm{X}$ \\
\hline $\begin{array}{l}\text { Curso de Contabilidade Aplicada ao Setor } \\
\text { Público Multiplicadores - TO }\end{array}$ & nov/11 & $\mathrm{X}$ & & $\mathrm{X}$ & $\mathrm{X}$ & & \\
\hline $\begin{array}{l}\text { Formação de Multiplicadores em Contabilidade } \\
\text { Aplicada ao Setor Público e Demonstrativos } \\
\text { Fiscais - SP }\end{array}$ & $\mathrm{abr} / 12$ & $\mathrm{X}$ & & $\mathrm{X}$ & & & \\
\hline $\begin{array}{l}\text { Formação de Multiplicadores em Contabilidade } \\
\text { Aplicada ao Setor Público e Demonstrativos } \\
\text { Fiscais - BA }\end{array}$ & jun/12 & $\mathrm{X}$ & & $\mathrm{X}$ & & & \\
\hline $\begin{array}{l}\text { Formação de Multiplicadores em Contabilidade } \\
\text { Aplicada ao Setor Público e Demonstrativos }\end{array}$ & $\mathrm{jul} / 12$ & $\mathrm{X}$ & & $\mathrm{X}$ & & & \\
\hline
\end{tabular}




\begin{tabular}{|c|c|c|c|c|c|c|c|}
\hline Fiscais - PA & & & & & & & \\
\hline $\begin{array}{l}\text { Formação de Multiplicadores em Contabilidade } \\
\text { Aplicada ao Setor Público e Demonstrativos } \\
\text { Fiscais -MG }\end{array}$ & set/12 & $X$ & & $\mathrm{X}$ & & & \\
\hline $\begin{array}{l}\text { Formação de Multiplicadores em Contabilidade } \\
\text { Aplicada ao Setor Público e Demonstrativos } \\
\text { Fiscais - GO }\end{array}$ & nov/12 & $X$ & & $X$ & & & \\
\hline $\begin{array}{l}\text { Capacitação em Contabilidade Aplicada ao Setor } \\
\text { Público São Paulo/SP }\end{array}$ & mai/12 & $X$ & $X$ & & $X$ & $X$ & $X$ \\
\hline $\begin{array}{l}\text { Capacitação em Contabilidade Aplicada ao Setor } \\
\text { Público e Lei de Responsabilidade Fiscal - LRF - } \\
\text { Fortaleza/CE }\end{array}$ & jun/12 & $\mathrm{X}$ & $X$ & $X$ & $\mathrm{X}$ & $X$ & $\mathrm{X}$ \\
\hline $\begin{array}{l}\text { I Seminário Brasileiro de Contabilidade Aplicada } \\
\text { ao Setor Público - I SBCASP }\end{array}$ & mai/13 & $X$ & $\mathrm{X}$ & $\mathrm{X}$ & & & $\mathrm{X}$ \\
\hline $\begin{array}{l}\text { Alinhamento Técnico e Pedagógico em } \\
\text { Contabilidade Aplicada ao Setor Público - CASP } \\
\text { e em Demonstrativos Fiscais - MDF }\end{array}$ & ago/14 & $\mathrm{X}$ & & $X$ & & & \\
\hline $\begin{array}{l}\text { Seminário Brasileiro de Contabilidade Aplicada } \\
\text { ao Setor Público - II SBCASP }\end{array}$ & mai/14 & $X$ & $X$ & $X$ & & & $\mathrm{X}$ \\
\hline $\begin{array}{l}\text { I Encontro de Gestores Públicos sobre a Nova } \\
\text { CASP EGP/CASP } 2015 \text { - Maceió-AL }\end{array}$ & mai/15 & $X$ & $X$ & & & & $\mathrm{X}$ \\
\hline $\begin{array}{l}\text { I Semana Contábil e Fiscal para Estados e } \\
\text { Municípios - SECOFEM - 2015. Brasília - DF }\end{array}$ & $\operatorname{mar} / 15$ & $X$ & $X$ & $X$ & & & \\
\hline $\begin{array}{l}\text { II Semana Contábil e Fiscal para Estados e } \\
\text { Municípios - SECOFEM - Maceió - AL 2015 }\end{array}$ & jun/15 & $X$ & $X$ & & & & \\
\hline $\begin{array}{l}\text { III Semana Contábil e Fiscal para Estados E } \\
\text { MunicípioS SECOFEM - Rio de Janeiro - RJ } \\
2015\end{array}$ & ago/15 & $X$ & $X$ & $X$ & & & $\mathrm{X}$ \\
\hline $\begin{array}{l}\text { IV Semana Contábil e Fiscal para Estados e } \\
\text { Municípios SECOFEM - 2015 - Cuiabá/MT }\end{array}$ & nov/15 & $X$ & $X$ & & & & $\mathrm{X}$ \\
\hline $\begin{array}{l}\text { Alinhamento Técnico e Pedagógico em: } \\
\text { - Contabilidade Aplicada ao Setor Público - } \\
\text { CASP; } \\
\text { - Demonstrativos Fiscais } \\
\text { - Sistema de Informações sobre Orçamentos } \\
\text { Públicos em Saúde - SIOPS - Adequações ao } \\
\text { PCASP; } \\
\text { - Sistema de Informações sobre Orçamentos } \\
\text { Públicos em Educação }- \text { SIOPE e } \\
\text { - Regime Próprio de Previdência Social - RPPS } \\
\end{array}$ & fev/16 & $X$ & $X$ & $X$ & & & \\
\hline $\begin{array}{l}\text { V Semana Contábil e Fiscal para Estados e } \\
\text { Municípios-SECOFEM. Brasília-DF }\end{array}$ & $\mathrm{fev} / 16$ & $X$ & $X$ & & & & $\mathrm{X}$ \\
\hline $\begin{array}{l}\text { II Encontro de Gestores Públicos sobre a nova } \\
\text { CASP EGP/CASP 2016 - Curitiba/PR }\end{array}$ & mar/16 & $\mathrm{X}$ & $X$ & & $\mathrm{X}$ & & $\mathrm{X}$ \\
\hline $\begin{array}{l}\text { VI SECOFEM - Semana Contábil e Fiscal para } \\
\text { Estados e Municípios - Curitiba-PR }\end{array}$ & $\mathrm{abr} / 16$ & $X$ & $X$ & & $\mathrm{X}$ & & $\mathrm{X}$ \\
\hline $\begin{array}{l}\text { III Encontro de Gestores Públicos sobre a nova } \\
\text { CASP EGP/CASP 2016 - Belém/PA }\end{array}$ & mai/16 & $X$ & $X$ & & $X$ & & $X$ \\
\hline $\begin{array}{l}\text { VII SECOFEM - Semana Contábil e Fiscal para } \\
\text { Estados e Municípios - Belém-PA }\end{array}$ & jun/16 & $X$ & $X$ & $X$ & $X$ & $\mathrm{X}$ & $\mathrm{X}$ \\
\hline
\end{tabular}

Fonte: Elaboração própria.

Quanto à tabela, vale acrescentar que a Escola de Administração Fazendária (ESAF) é um órgão subordinado ao Ministério da Fazenda que atua na promoção de aperfeiçoamento técnico-profissional de servidores. Além disso, a última coluna, denominada de "Outros" abrange universidades públicas e privadas, fundações, institutos e associações, tais como: 
Instituto Iris, IRB, ATRICON, BM, BB e CNM.

No que tange à influência dos Tribunais de Contas no processo de convergência da contabilidade pública às normas internacionais, alguns estudos têm buscado evidenciar as ações que estão sendo realizadas (KUTIANSKI, 2015; LINO, 2015). Nesse sentido, vale ressaltar novamente a importância de seu papel nesse processo, pois devem fiscalizar os gestores públicos no que se refere implantação efetiva das novas regras contábeis.

No relatório sobre as contas do Governo da República do ano de 2014, elaborado pelo TCU, há menções ao processo de convergência às normas internacionais de contabilidade para o setor público, e reconhecimento das IPSAS como ponto de partida para a regulamentação contábil.

Também, encontram-se disponíveis palestras de capacitação sobre o processo realizado por diversos TCs, e observa-se a participação da Atricon nos grupos de convergência e em ações com cooperação técnica com o CFC, no entanto, essa participação ainda se dá de maneira incipiente. Segundo Lino (2015), “durante toda a discussão normativa sobre a convergência para as IPSAS, os TCs participaram apenas marginalmente do processo". Isso é suportado pelo levantamento das ações realizadas pelo órgão relacionadas ao processo de convergência e a opinião captada nas entrevistas e questionários.

Assim, na prática, a participação do TCU e dos TCs de forma direta e em discussões conceituais ainda não é forte. Todavia, recentemente, observa-se um maior envolvimento desses atores nesse processo, uma vez que alguns dos relatórios sobre as contas anuais do chefe do Poder Executivo já consideram aspectos trazidos no MCASP e os prazos de adoção de procedimentos dispostos pela STN. Vale acrescentar que ainda que embora alguns TCs estejam atuando de maneira mais ativa no processo de convergência nos âmbitos Estaduais e Municipais, esses ainda são a minoria.

Quanto à influência da academia, segundo o entrevistado da STN, a partir do início do processo houve um maior estímulo para desenvolvimento de pesquisas na área pública, contudo, apesar do crescimento do número de trabalhos, entende que não houve o mesmo crescimento no número de orientadores e avaliadores de artigos científicos, bem como uma evolução da área pública nos cursos de graduação de ciências contábeis, considerando que não houve muita diferença na oferta de disciplinas relacionadas. Na opinião do entrevistado do CFC, as universidades têm contribuído por meio de seus representantes. Já para o entrevistado do TCU, poucos acadêmicos participaram e influenciaram o processo ativamente, destacando a necessidade de maiores discussões conceituais no setor público e uma visão crítica acerca do processo de convergência. 
Considerando, ainda, a escassez na literatura brasileira de pesquisas que tratam a convergência das normas de contabilidade do setor público (FRAGOSO et al., 2012) e que o tema vem sendo discutido na academia sob uma perspectiva operacional (CARVALHO; COSTA; OLIVEIRA, 2010; SILVA et al., 2012; VIANA et al. 2013; SILVA et al., 2014), nota-se que a academia pode contribuir mais ativamente nas discussões acerca da condução e promoção do processo de convergência.

Em relação aos atores, solicitou-se no questionário que os respondentes apontassem os principais envolvidos na promoção e no direcionamento do processo de convergência das normas brasileiras de contabilidade às normas internacionais. Dessa forma, houve um predomínio nas respostas da STN e CFC, respectivamente nesta ordem.

Corroborando com a visão de Gama, Duque e Almeida (2014), outro ator que foi bastante citado nos questionários e merece destaque é o GTCON. Nesse sentido, apesar de se ter “[...] a impressão de que a STN ouvia as sugestões dos participantes, mas se reservava o direito de dar a palavra final nos assuntos mais polêmicos [...]", Neves (2014, p. 14) destaca que "Com o tempo percebemos que não poderia ter sido muito diferente disso, pois não é fácil ter consenso sobre questões antigas, mas complexas [...]". Assim, o grupo técnico tem obtido visibilidade na busca de um processo mais colaborativo e com representatividade nacional. No entanto, nesta pesquisa considerou-se o GTCON como uma ação da STN, tendo em vista que foi criado e é conduzido pelo referido órgão.

A percepção de diversos agentes envolvidos no processo de convergência, obtida nos questionários, corrobora com as informações obtidas na revisão da literatura e nas entrevistas, permitindo evidenciar um ranking dos mais influentes: STN, CFC, TCU, TCs e Academia.

Tabela 2 - Influência dos Atores no Processo de Convergência Brasileiro

\begin{tabular}{|c|c|c|c|c|c|c|}
\hline Influência & Muito Baixa & Baixa & Média & Alta & Muito Alta & RM \\
\hline Academia (universidades) & $12,90 \%$ & $29,03 \%$ & $27,42 \%$ & $20,97 \%$ & $9,68 \%$ & 2,85 \\
\hline $\begin{array}{c}\text { Conselho Federal de Contabilidade } \\
\text { (CFC) }\end{array}$ & $0,00 \%$ & $1,61 \%$ & $17,74 \%$ & $40,32 \%$ & $40,32 \%$ & 4,19 \\
\hline $\begin{array}{c}\text { Secretaria do Tesouro Nacional (STN) } \\
\text { Tribunal de Contas da União }\end{array}$ & $1,67 \%$ & $11,67 \%$ & $35,00 \%$ & $36,67 \%$ & $15,00 \%$ & 3,52 \\
\hline $\begin{array}{c}\text { Tribunais de Contas (TCs) Estaduais e } \\
\text { Municipais }\end{array}$ & $6,78 \%$ & $15,25 \%$ & $32,20 \%$ & $25,42 \%$ & $20,34 \%$ & 3,37 \\
\hline
\end{tabular}

Fonte: Elaboração própria.

Assim, conforme a Tabela 2, os atores que apresentam um maior ranking médio são a STN e o CFC. Em ambos não houve nenhuma percepção de influência muito baixa. O TCU apresenta-se logo em seguida, mas com um ranking médio consideravelmente inferior ao dos 
primeiros atores. A percepção acerca da influência dos TCs demonstra-se similar à do TCU. Por fim, a academia apresenta um ranking médio inferior a 3, indicando que não tem exercido influência no processo de convergência.

Dessa forma, as ações realizadas pelos principais atores no processo de convergência da contabilidade pública brasileira às IPSAS são sintetizadas no quadro 4.

\begin{tabular}{|c|c|c|}
\hline \multicolumn{3}{|c|}{$\begin{array}{l}\text { Quadro } 4 \text { - Ações } \\
\text { Internacionais } \\
\text { Atores }\end{array}$} \\
\hline Atores & \multicolumn{2}{|c|}{ Ações Realizadas } \\
\hline \multirow{8}{*}{ CFC } & \multirow{5}{*}{ Emissão de normativos } & Portaria CFC n 37 \\
\hline & & Orientações Estratégicas CFC \\
\hline & & Resolução CFC n ${ }^{\circ} 1.111$ \\
\hline & & NBC T 16 \\
\hline & & NBC TSP \\
\hline & Outras Publicações & Tradução das IPSAS \\
\hline & Atualizações & $\begin{array}{l}\text { Portarias de composição de Grupos atuantes na } \\
\text { área de Contabilidade Pública (Anexo B) }\end{array}$ \\
\hline & Outras ações & $\begin{array}{l}\text { Acordos de Cooperação Técnica e Parcerias } \\
\text { (especialmente para capacitações) }\end{array}$ \\
\hline \multirow{14}{*}{ STN } & \multirow{8}{*}{ Emissão de normativos } & Portaria STN nº $135 / 07$ - GTREL \\
\hline & & Portaria STN no ${ }^{\circ} 136 / 07$ - GTCON \\
\hline & & Portaria MF nº $184 / 08$ \\
\hline & & $1^{\text {a }}$ edição do MCASP - 2008 \\
\hline & & Portaria STN nº 467/09 \\
\hline & & Portaria STN no $111 / 11$ - criação GTSIS \\
\hline & & Portaria STN n ${ }^{\circ} 634 / 13$ (prazos vigentes) \\
\hline & & $\begin{array}{l}\text { PIPCP- } 2015 \text { (detalhamento da Portaria } n^{\circ} \\
634 / 13 \text { ) }\end{array}$ \\
\hline & \multirow[b]{2}{*}{ Outras Publicações } & Instruções de Procedimentos Contábeis (IPCs) \\
\hline & & $\begin{array}{l}\text { Cartilha Nova Contabilidade e Gestão Fiscal: } \\
\text { Modernizando a Gestão Pública }\end{array}$ \\
\hline & \multirow[b]{2}{*}{ Atualizações } & MCASP (Atualmente está na $7^{\mathrm{a}}$ edição) \\
\hline & & $\begin{array}{l}\text { Portarias STN referentes a prazos, totalizando } \\
\text { seis: 664/2010; 828/201; 437/2012; 753/2012; } \\
\text { 634/2013. }\end{array}$ \\
\hline & \multirow[b]{2}{*}{ Outras ações } & Alinhamento Técnico e Pedagógico - ATP \\
\hline & & $\begin{array}{l}\text { Acordos de Cooperação Técnica e Parcerias } \\
\text { (especialmente para capacitações) }\end{array}$ \\
\hline \multirow{2}{*}{ TCU } & Emissão de normativos & Acórdãos TCU n ${ }^{\circ} 158 / 12$ e nº 1979/12 \\
\hline & Outros & Acordo de Cooperação Técnica \\
\hline
\end{tabular}

Fonte: Elaboração própria.

A premissa inicialmente assumida, de que quanto mais ações realizadas pelos atores, maior a sua capacidade de influência, corrobora com as percepções dos envolvidos no processo. Quanto às ações, nota-se que a maioria que foram realizadas até o momento voltaram-se para o fortalecimento da contabilidade pública, a partir da reafirmação de sua condição como ciência e de seu objeto de estudo, isto é, o patrimônio público, conforme as Orientações Estratégicas emitidas pelo CFC.

Ressalta-se que ações mais lembradas, nos questionários, foram: a adoção do PCASP, seguido pela emissão dos MCASP e, de maneira geral, o resgate do enfoque patrimonial. 
Assim, nota-se que além da STN ter realizado mais ações na promoção e condução da reforma, os seus produtos (PCASP e MCASP) foram os mais citados pelos participantes, evidenciando sua influência. No entanto, deve-se ressaltar que o PCASP deveria ser adotado obrigatoriamente por todos os entes no exercício de 2015, podendo ser uma possível razão por que ter sido bastante citado. Ademais, a emissão quase que anual do MCASP e o seu viés operacionalizador das normas, demonstra que as ações percebidas como mais impactantes na condução do processo reforma da contabilidade pública são aquelas realizadas mais recentemente e com influência direta no cotidiano dos envolvidos.

Embora a STN tenha se destacado mais quanto à realização de ações com vistas à implantação das normas, o CFC tem se mostrado fundamental para concretização dessas, especialmente nas ações de capacitação. Os atores têm atuado mediante cooperações técnicas, de forma que o CFC basicamente arca com os recursos financeiros necessários para a promoção e divulgação das normas contábeis aplicáveis ao setor público e a STN com os recursos humanos. Considerando a situação econômica atual, tem-se que sem o apoio financeiro do órgão de classe contábil, a condução do processo de convergência estaria bastante prejudicada.

Revoredo (2008) analisou o processo de convergência brasileiro em 2008 mediante a utilização do modelo FMR, segunda a autora diferentemente do que ocorre nos países europeus e suas ex-colônias, de maneira geral, no Brasil a organização profissional tinha um alto potencial de influência através da organização conjunta e atuação proativa. Atualmente, considerando as ações realizadas pelo órgão de classe e a importância das parcerias e cooperações na condução do processo de implementação, pode-se afirmar que o CFC é um ator que influência, de fato, na promoção e no direcionamento dessa reforma da contabilidade pública brasileira. No entanto, nesse ponto, deve-se apontar a necessidade de se observar a composição dos Grupos do CFC, tendo em vista a atual predominância de membros da STN, para que sejam representativos do maior número de atores possível.

Ainda, considerando as dificuldades encontradas, e algumas já até reconhecidas pelos principais atores envolvidos, recomenda-se que as ações futuras passem a focar também em outros usuários da informação, especialmente gestores e membros do legislativo. Dessa forma, ressalta-se a necessidade de um maior envolvimento e interação dos atores no processo para a desinstitucionalização e institucionalização das novas práticas contábeis. 


\section{CONSIDERAÇÕES FINAIS}

O presente estudo teve como objetivo analisar a influência dos atores no processo de convergência da contabilidade pública brasileira aos padrões internacionais, tendo como suporte teórico a Teoria Institucional e a revisão da literatura sobre o tema, mediante a aplicação de entrevistas e questionário semiestruturado, utilizando-se o software NVivo para subsidiar a análise de conteúdo realizada.

A revisão da literatura trouxe que internacionalmente há uma tendência em direção a adoção das IPSAS, seja em razão da ausência de outro padrão no setor público com o intuito de ser internacional ou devido à uma visão de que essas normas são capazes de contribuir para a melhoria das informações contábeis. A atuação de órgãos supranacionais e multilaterais é destacada, especialmente de instituições financeiras como o FMI e o BM, na promoção de tais normas.

Do ponto de vista institucional, verificou-se que no Brasil os estímulos para a atuação dos atores na reforma da contabilidade pública foram diferentes: enquanto o CFC passou a abordar o assunto por pressões normativas relacionadas a demandas da própria profissão contábil, a motivação da STN pareceu estar mais relacionada com a necessidade de padronização e consolidação das contas públicas, sendo influenciada pelas demandas da FMI quanto à elaboração das estatísticas fiscais. No entanto, observa-se que existia uma necessidade de uniformização e padronização dentro do próprio país, e essa necessidade de reforma da contabilidade pública apareceu como determinante para a escolha, a posteriori, da convergência às normas internacionais.

Os achados do estudo permitem concluir o processo de convergência teve início com a publicação pelo Conselho Federal de Contabilidade das Orientações Estratégicas para o Desenvolvimento da Contabilidade Pública no Brasil. Mas, formalmente, o processo iniciou, em 2008, com a publicação da Portaria $n^{\circ} 184$ pelo Ministério da Fazenda, sendo também publicados, no mesmo ano, as primeiras Normas Brasileiras de Contabilidade Aplicadas ao Setor Público (NBCASP), emitidas pelo CFC, e o Manual de Contabilidade Aplicado ao Setor Público (MCASP), publicado pela STN.

Assim, verificou-se que nos primeiros anos o CFC teve uma maior atuação, emitindo verdadeiros marcos na contabilidade pública brasileira. Posteriormente, STN passou a assumir um papel de destaque na condução do processo de convergência brasileiro, atuando mediante normativos, dispondo sobre prazo de aplicação dos procedimentos contábeis convergidos, editando manuais e instruções de aplicação prática, realizando cursos de capacitação, entre 
outros. Apesar de a STN ter realizado mais ações e possuir mais visibilidade, no processo como um todo, considerando as ações colaborativas entre a STN e o CFC, afirma-se que esses órgãos são os atores mais influentes no contexto brasileiro de convergência aos padrões contábeis internacionais. Quanto ao TCU e os TCs, esses ainda não desempenham um papel ativo na implantação das normas contábeis, sendo que a situação dos TCs no Brasil mostra ser muito desigual. E, apesar dos avanços, a atuação da academia não demonstrou ser influente na condução das normas de contabilidade pública.

Apesar de ter iniciado em meados de 2007, o processo teve um avanço nos primeiros anos, passando por uma fase de esfriamento entre 2010 a 2014, marcada, segundo os entrevistados, pela falta de mecanismos de enforcement para o cumprimento da implementação das normas. Entretanto, as ações desenvolvidas desde o fim de 2015 e as programadas para os próximos anos demonstram um aperfeiçoamento no planejamento, conceito e estratégia de reforma.

Assim, evidencia-se um amadurecimento dos atores envolvidos na promoção e no direcionamento diante do reconhecimento da falta de planejamento e estratégia bem definidos para a condução do processo de reforma no país. Passou-se a ter uma maior divulgação das ações realizadas e houve a elaboração de um planejamento, dessa vez, mais propício de ser seguido e, consequentemente, obter êxito, tendo em vista que passa a considerar algumas particularidades do cenário brasileiro.

No entanto, considerando o contexto atual, pode-se dizer que o processo de convergência ainda está em seu estágio inicial. Ressalta-se ainda que o processo de mudança é lento e gradual, tendo em vista que há a necessidade de desinstitucionalização e institucionalização das novas práticas contábeis. No entanto, considerando que é necessário o alinhamento dos três pilares (regulatório, normativo e cultural-cognitivo) para que se tenha um fortalecimento da contabilidade aplicada ao setor público, mostra-se necessário que exista um maior envolvimento e interação dos outros atores no processo, de forma que compreendem, aceitem e suportem a reforma em andamento.

Ademais, o estudo demonstrou que o país está lidando mais com barreiras de transição práticas do que de barreiras de transição conceituais. Em um próximo momento do processo, estas últimas podem ficar mais aparentes, o que destaca a necessidade de buscar maior envolvimento de outros atores, especialmente da academia.

Dessa forma, conclui-se que os principais atores na promoção e direcionamento do processo de convergência brasileiro às normas internacionais são: a STN, o CFC e o TCU, embora os dois primeiros são os que mais influenciam diretamente. Além disso, as ações 
realizadas ainda não se mostram suficientes para superar as barreiras impostas pelo próprio cenário brasileiro e ainda há um caminho longo a ser percorrido para que ocorra a institucionalização dos novos padrões contábeis.

Considerando ainda que alertam que análises institucionais comparativas têm sido negligenciadas no âmbito da investigação de contabilidade pública internacional (CHAN; YUNXIAO, 2008, p. 89), sugere-se que pesquisas futuras realizem estudos comparativos de como o processo de convergência da contabilidade pública está ocorrendo em países emergentes da América Latina. Por exemplo, Argentina e México são países da América Latina com expressividade econômica, que possuem em comum com o Brasil a forma de Estado Federado, sendo que a disposição institucional também é similar, tendo em vista que o sistema legal é code law e a cultura é semelhante, de acordo com as dimensões culturais de Hofstede.

Além disso, considerando que tamanho da jurisdição também influencia o processo de reformas contábeis (OUDA, 2004), como os três países juntos correspondem a cerca de 65\% da superfície da América Latina e Caribe, e contribuem com mais de 70\% do PIB da referida região, demonstram ser um caso interessante para tal análise. Recomenda-se, ainda, que pesquisas futuras incluam também a visão de outros atores, especialmente de políticos, acerca do processo de convergência da contabilidade pública. 


\section{REFERÊNCIAS}

ADHIKARI, Pawan; GÅRSETH-NESBAKK, Levi. Implementing public sector accruals in OECD member states: Major issues and challenges. Accounting Forum, v. 40, p. 125-142, 2016.

ADHIKARI, Pawan; MELLEMVIK, Frode. The adoption of IPSASs in South Asia: A comparative study of seven countries. Research in Accounting in Emerging Economies, v. 10, p. 169-199, 2010.

AHN, Paul D. et al. Beyond Self-Evident: Recognising the Problematic Political Context of Accrual Accounting Adoption in South Korea. Financial Accountability \& Management, v. 30, n. 1, p. 25-48, 2014.

ALBU, Cătălin Nicolae; ALBU, Nadia; ALEXANDER, David. When global accounting standards meet the local context-Insights from an emerging economy. Critical Perspectives on Accounting, v. 25, n. 6, p. 489-510, 2014.

ALESANI, Daniele; JENSEN, Gwenda; STECCOLINI, Ileana. IPSAS adoption by the World Food Programme: an application of the contingency model to intergovernmental organisations. International Journal of Public Sector Performance Management, v. 2, n. 1, p. 61-80, 2012.

ALEXANDRINO, Marcelo; PAULO, Vicente. Direito Administrativo Descomplicado. 18ed. Rio de Janeiro: Forense; São Paulo: Método, 2010.

AMARAL, Guilherme F.; LIMA, Diana V. A contribuição da nova contabilidade pública sobre os efeitos dos ciclos políticos no Brasil. Revista Ambiente Contábil, v. 5, n. 2, p. 173$189,2013$.

ANTIPOVA, Tatiana; BOURMISTROV, Anatoli. Is Russian public sector accounting in the process of modernization? An analysis of accounting reforms in Russia. Financial

Accountability \& Management, v. 29, n. 4, p. 442-478, 2013.

ARGENTO, Daniela; VAN HELDEN, G. Jan. Water sector reform in Italy and in the Netherlands: ambitious change with an uncertain outcome versus consensus-seeking moderate change. International Review of Administrative Sciences, v. 76, n. 4, p. 790-809, 2010.

BARDIN, Laurence. Análise de Conteúdo. rev. Lisboa: Edições, v. 70, 2009.

BARATTER, Marystela A.; FERREIRA, Jane M.; COSTA, Mayla C. Empreendedorismo Institucional: características da ação intencional. Perspectivas Contemporâneas, p. 237-266, 2010.

BATTILANA, Julie. Agency and institutions: The enabling role of individuals' social position. Organization, v. 13, n. 5, p. 653-676, 2006. 
BELKAOUI, Ahmed. Economic, political, and civil indicators and reporting and disclosure adequacy: Empirical investigation. Journal of Accounting and Public Policy, v. 2, n. 3, p. 207-219, 1983.

BENITO, Bernardino; BRUSCA, Isabel; MONTESINOS, Vicente. The harmonization of government financial information systems: the role of the IPSAS. International Review of Administrative Sciences, 73(2), p. 293-317, 2007.

BÉDARD, Jean; GENDRON, Yves. Qualitative Research on Accounting: some thoughts on what occurs behind the scene. The Real Life Guide to Accounting Research, p. 191-206, 2004.

BIONDI, Yuri. Harmonising European Public Sector Accounting Standards (EPSAS): Issues and Perspectives for Europe's Economy and Society. Accounting, Economics and Law, v. 4, n. 3, p. 165-178, 2014.

BONI, Valdete. QUARESMA, Silvia Jurema Quaresma. Aprendendo a entrevistar: como fazer entrevistas em Ciências Sociais. Em Tese, Vol. 2 n. ${ }^{\circ} 1$ (3), janeiro/julho, 2005, p. 6880 .

BORGES, Thiago Bernardo. Utilização da Informação Gerencial no Setor Público: Perspectiva Diante Das Novas Normas De Contabilidade Do Setor Público. 2012. 262 f. Dissertação (mestrado) - Universidade Federal de Minas Gerais, Centro de Pós-Graduação e Pesquisas em Contabilidade e Controladoria, Belo Horizonte. 2012.

BRASIL. Constituição da República Federativa do Brasil. Constituição de 1988. Disponível em: <http://www.presidencia.gov.br>. Acesso em: 03 ago. 2016.

Decreto $n^{0}$ 92.452/1986, de 10 de março de 1986. Cria, no Ministério da Fazenda, a Secretaria do Tesouro Nacional (STN), extingue a Secretaria Central de Controle Interno (SECIN), e dá outras providências. Disponível em:

<http://www.planalto.gov.br/ccivil_03/decreto/1980-1989/1985-1987/D92452.htm>. Acesso em: 4 ago. 2016.

Decreto no 6.976, de 7 de outubro de 2009. Dispõe sobre o Sistema de Contabilidade Federal e dá outras providências. Disponível em: <http://www.planalto. gov.br/ccivil_03/_Ato2007-2010/2009/Decreto/D6976.htm>. Acesso em: 1 ago. 2016.

Escola Nacional de Administração Pública (ENAP). Servidores Públicos Federais Perfil - 2015. Brasília, 2015.

Lei Complementar $n^{0}$ 101, de 4 de maio de 2000. Estabelece normas de finanças públicas voltadas para a responsabilidade fiscal e dá outras providências. Disponível em: <http://www.planalto.gov.br/ccivil_03/leis/lcp/lcp101.htm>. Acesso em: 4 ago. 2016.

Lei $\mathrm{n}^{\circ}$ 10.180/2001, de 6 de fevereiro de 2001. Organiza e disciplina os Sistemas de Planejamento e de Orçamento Federal, de Administração Financeira Federal, de Contabilidade Federal e de Controle Interno do Poder Executivo Federal, e dá outras providências. Disponível em: <http://www.planalto.gov.br/ccivil_03/leis/leis_2001/L10180.htm>. Acesso em: 1 ago. 2016. 
Lei Federal no 4.320, de 17 de março de 1964. Estatui normas gerais de direito nanceiro para elaboração dos orçamentos e balanços da União, dos Estados, dos Municípios e do Distrito Federal. Disponível em: 〈http://www.planalto.gov.br/ccivil_03/leis/L4320.htm〉. Acesso em: 4 ago. 2016.

Projeto de Lei Complementar 295/2016. Disponível em:

<http://www.camara.gov.br/proposicoesWeb/fichadetramitacao?idProposicao=2088990>. Acesso em: 05 dez. 2016.

Secretaria do Tesouro Nacional. Contabilidade Pública.

Secretaria do Tesouro Nacional. Portaria MF n⿳ 184, de 25 de agosto de 2009.

Dispõe sobre as diretrizes a serem observadas no setor público (pelos entes públicos) quanto aos procedimentos, práticas, elaboração e divulgação das demonstrações contábeis, de forma a torná-los convergentes com as Normas Internacionais de Contabilidade Aplicadas ao Setor Público. Disponível em: < http://www.fazenda.gov.br/acesso-ainformacao/institucional/legislacao/2008/portaria184>. Acesso em: 13 ago. 2016.

BRUSCA, Isabel; MARTÍNEZ, Juan Carlos. Adopting International Public Sector Accounting Standards: a challenge for modernizing and harmonizing public sector accounting. International Review of Administrative Sciences, p. 01-21, 2015.

BRUSCA, Isabel; MONTESINOS, Vicente; CHOW, Danny S. Legitimating international public sector accounting standards (IPSAS): the case of Spain. Public Money \& Management, v. 33, n. 6, p. 437-444, 2013.

BRUSCA, Isabel; GÓMEZ-VILLEGAS, Mauricio; MONTESINOS, Vicente. Public Financial Management Reforms: The Role of IPSAS in Latin-America. Public Administration and Development, v. 36, n. 1, p. 51-64, 2016.

BURNS, John; SCAPENS, Robert W. Conceptualizing management accounting change: an institutional framework. Management accounting research, v. 11, n. 1, p. 3-25, 2000.

CABA-PEREZ, Carmen; LÓPEZ-HERNÁNDEZ, Antonio M.; ORTIZ-RODRÍGUEZ, David. Governmental financial information reforms and changes in the political system: the Argentina, Chile and Paraguay experience. Public Administration and Development, v. 29, n. 5, p. 429-440, 2009.

CARVALHO, Luiz Nelson Guedes de; COSTA, Patrícia de Souza; OLIVEIRA, Alan de Teixeira. Impairment no setor público: particularidades das normas nacionais e internacionais. Revista de Administração Pública, v. 44, n. 4, p. 839-876, 2010.

CAVANAGH, Joseph; BENITO, Almudena Fernández. Contabilidad pública y credibilidad fiscal. In: PIMENTA, Carlos; PESSOA, Mario (Ed.). Gestión financiera pública en América Latina: La clave de la eficiencia y la transparência. 2015, p.191-249.

CAVANAGH, Joe; FLYNN, Suzanne; MORETTI, Delphine. Implementing Accrual Accounting in the Public Sector. International Monetary Fund, Fiscal Affairs Department, 2016. 
CFC. Conselho Federal de Contabilidade. Agência de Notícias, 2016.

Conselho Federal de Contabilidade. Pesquisa perfil do profissional da contabilidade

2012/13. Brasília: CFC, 2013.

Conselho Federal de Contabilidade. Normas Internacionais de Contabilidade

aplicadas ao Setor Público, 2010.

Conselho Federal. Orientações estratégicas para a contabilidade aplicada ao setor público no Brasil. Brasília, DF, 2007.

CHAN, James L. International Public Sector Accounting Standards: Conceptual and Institutional Issues. The Harmonization of Government, 21, p. 1-15, 2008.

CHAN, James L. As NICSPS e a Contabilidade Governamental de Países em Desenvolvimento. Revista de Educação e Pesquisa em Contabilidade, Brasília, v. 4, n. 1, p. 1-17, jan./abr. 2010.

CHAN, James L.; JONES, Rowan H.; LÜDER, Klaus G. Modeling Governmental Accounting Innovations. Research in Governmental and Nonprofit Accounting, v. 9, p. 119, 1996.

CHAN, James; YUNXIAO, Xu. Setting government accounting standards: a comparative institutional analysis of China and The United States Implementing reforms in public sector accounting. Coimbra, 2008. Disponível em: 〈https://digitalis.uc.pt/handle/10316.2/32141〉.

CHRISTIAENS, Johan et al. The effect of IPSAS on reforming governmental financial reporting: An international comparison. International Review of Administrative Sciences, v. 81 , n. 1, p. 158-177, 2015.

CHRISTIAENS, Johan; REYNIERS, Brecht; ROLLÉ, Caroline. Impact of IPSAS on reforming governmental financial information systems: A comparative study. International Review of Administrative Sciences, v. 76, n. 3, p. 537-554, 2010.

CIESLEWICZ, Joshua K. Relationships between national economic culture, institutions, and accounting: Implications for IFRS. Critical Perspectives on Accounting, 25, p. 511-528, 2014.

COVALESKI, Mark A.; DRISMITH, Mark W.; WEISS, Jane M. The social construction, challenge and transformation of a budgetary regime: The endogenization of welfare regulation by institutional entrepreneurs. Accounting, Organizations and Society, v. 38, n. 5, p. 333-364, 2013.

CRUVINEL, Daniel Pereira; LIMA, Diana Vaz de. Adoção do regime de competência no setor público brasileiro sob a perspectiva das normas brasileiras e internacionais de Contabilidade. Revista de Educação e Pesquisa em Contabilidade, Brasília, n. 3, p. 69-85, set./dez. 2011.

DAHL, Robert. A critique of the Ruling-Elite model. American Political Science Review, 52, 1958. 
DIMAGGIO, Paul J.; POWELL, Walter W. The iron cage revisited: institutional isomorphism and collective rationality in organizational fields. American Sociological Review, v. 48, n. 2, p.147-160, 1983.

DI PIETRO, Maria S. Z. Direito Administrativo. 27 ed. São Paulo: Atlas, 2014.

DJELIC, Marie-Laure; QUACK, Sigrid. Institutions and transnationalization. In: Greenwood R, Oliver C, Suddaby R, Sahlin K, editors. The SAGE handbook of organizational institutionalism. London: Sage Publications, p. 299-323, 2008.

EZZAMEL, Mahmoud et al. Discourse and institutional change: 'Giving accounts' and accountability. Management Accounting Research, v. 18, n. 2, p. 150-171, 2007.

FACHIN, Roberto C.; MENDONÇA, J. Ricardo C. O conceito de profissionalização e da teoria institucional. Organizações, instituições e poder no Brasil. Rio de Janeiro: FGV, p. 19-41, 2003.

FEIJÓ, Paulo H.; RIBEIRO, Carlos E. Entendendo o Plano de Contas Aplicado ao Setor Público (PCASP). Brasília: Editora Gestão Pública. Brasília, 2014.

FRAGOSO, Adriana R. et al. Normas Brasileiras e Internacionais de Contabilidade Aplicadas ao Setor Público e o Desafio da Convergência: uma Análise Comparativa-IPSAS e NBCTSP. Revista de Educação e Pesquisa em Contabilidade (REPeC), v. 6, n. 4, p. 434447, out./dez. 2012.

GAMA, Janyluce R.; DUQUE, Claudio G.; ALMEIDA, José E. F. Convergência brasileira aos padrões internacionais de contabilidade pública vis-à-vis as estratégias top-dow e bottomup. Revista de Administração Pública, v. 48, n. 1, p. 183-206, 2014.

GIACOMONI, James. Orçamento público. 14 ed. São Paulo: Atlas, 2007.

GODDARD, Andrew et al. The two publics and institutional theory - A study of public sector accounting in Tanzania. Critical Perspectives on Accounting, 2015.

GOMES, Patrícia S.; FERNANDES, Maria José; CARVALHO, João Baptista Da Costa. The International Harmonization Process of Public Sector Accounting in Portugal: The Perspective of Different Stakeholders. International Journal of Public Administration, v. 38, n. 4, p. 268-281, 2015.

GRECO, Marcus Vinicius Derito. Contabilidade governamental brasileira no contexto da convergência aos padrões internacionais. 2008. Dissertação (Mestrado em Gestão Empresarial) - Fundação Getúlio Vargas, Escola Brasileira de Administração Pública, Rio de Janeiro. 2008.

GUARIDO FILHO, Edson Ronaldo; COSTA, Mayla Cristina. Contabilidade e institucionalismo organizacional: fundamentos e implicações. Revista Contabilidade e Controladoria, v. 4, n. 1, p. 20-41, 2012.

GUERREIRO, Marta A. S. Enforcement - como garantir a correcta aplicação das normas internacionais de contabilidade? Revista TOC, v. 114, p. 19-26, set. 2009. 
GUERREIRO, Reinaldo et al. O entendimento da contabilidade gerencial sob a ótica da teoria institucional. Organizações \& Sociedade, v.12, n. 35, out./dez., p. 91-106, 2005.

HARUN, Harun; KAMASE, Haryono P. Accounting Change and Institutional Capacity: The Case of a Provincial Government in Indonesia. Australasian Accounting, Business and Finance Journal, v. 6, n. 2, p. 35-50, 2012.

HARUN, Harun et al. An Integrated Model of Institution and Its Application in Understanding the Adoption of IPSAS in Indonesian Local Governments. Conference: Comparative International Governmental Accounting Research Network, At Victoria University of Wellington, New Zealand, v. 7-9, 2016.

HASSAN, Enas A.; RANKIN, Michaela; LU, Wei. The development of accounting regulation in Iraq and the IFRS adoption decision: an institutional perspective. The International Journal of Accounting, v. 49, n. 3, p. 371-390, 2014.

HERBEST, F. G. Regime de competência no setor público: a experiência de implementação de diversos países. 2010. In: IV Congresso ANPCONT, 2010.

HOPWOOD, Anthony G.; MILLER, Peter. Accounting as Social and Institucional Practice. London: Cambridge University Press, 1994.

HYNDMAN, Noel et al. The translation and sedimentation of accounting reforms. A comparison of the UK, Austrian and Italian experiences. Critical Perspectives on Accounting, 25, p. 388-408, 2014.

IFAC. International Federation of Accountants. About IPSASB. USA: IFAC, 2016. 2014a. International Federation of Accountants. A Closer Look At: Costa Rica. USA: IFAC, IFAC, 2014b.

International Federation of Accountants. A Closer Look At: Switzerland. USA: . International Public Sector Accounting Standards Board Fact Sheet, 2015. $2013 \mathrm{a}$. $2013 b$. International Federation of Accountants. A Closer Look At: Malaysia. USA: IFAC,

INTOSAI. Internacional Organization of Supreme Audit Institutions. Disponível em: <http://www.intosai.org/en/news.html > Acesso em: 24 out. 2016.

JONES, Rowan; CARUANA, Josette. Governmental accounting in Malta towards IPSAS within the context of the European Union. International Review of Administrative Sciences, p. 1-18, 2015. 
JORGE, Susana. The reform of governmental accounting in Portugal: an application of Lüder's Contingency Model. In: Bourmistrov, Anatoli.; Mellemvik, Frode. International Trends and Experiences in Government Accounting, p. 28-48, 2005.

KAUARK, Fabiana S.; MANHÃES, Fernanda C.; MEDEIROS, Carlos H. Metodologia da pesquisa: um guia prático. Itabuna: Via Litterarum, v. 18, 2010.

KUTIANSKI, Sandi. Processo de Mudança da Contabilidade Aplicada ao Setor Público Sob a Ótica dos Órgãos Executores e Fiscalizadores do Estado do Paraná. 2015. 162f. Dissertação (mestrado) - Universidade Federal do Paraná, Programa de Pós-Graduação em Contabilidade, Curitiba. 2015.

LADIPO, Omowunmi; SÁNCHEZ, Alfonso; SOPHER, Jamil. Accountability in public expenditures in Latin America and the Caribbean: revitalizing reforms in financial management and procurement. World Bank Publications, 2009.

LEANDRO, Carlos A.; PÉREZ, Carmen C.; HERnÁNDEZ, Antonio M. L. Comparación descriptiva de los sistemas de información financiera gubernamental de los países centroamericanos. Contaduría Universidad de Antioquia, n. 60, p. 55-79, 2013.

LIMA, Bruno J. O impacto das dimensões culturais sobre a prática contábil no brasil: um olhar a partir da percepção dos operadores da contabilidade. Revista de Educação e Pesquisa em Contabilidade (REPeC), v. 10, n. 4, p. 363-379, 2016.

LINO, André F. Reforma da Contabilidade Pública e os Tribunais de Contas. 2015. 129 f. Dissertação (mestrado) - Faculdade de Economia, Administração e Contabilidade de Ribeirão Preto, Universidade de São Paulo, Ribeirão Preto, 2015.

LÜDER, Klaus. Research in comparative governmental accounting over the last decade: achievement and problems. In: MONTESINOS, V.; VELA, J.M. (Eds). Innovations in governmental accounting. Boston, MA: Kluwer Academic Publishers, 2001.

LÜDER, Klaus. "International Governmental Accounting Research", Private und Öffemtliche Rechnungslegun, (Spring), p. 235-250, 2009.

LUTHARDT, Ulf M. T. et al. Accounting Standards - A Success Story? An Empirical Investigation of the First FASB \& IASB Convergence Project. SSRN Working Paper Series, Rochester, Rochester, p. n/a, 2008.

MACHADO, Nelson; HOLANDA, Victor Branco. Diretrizes e modelo conceitual de custos para o setor público a partir da experiência no governo federal do Brasil. Revista de Administração Pública, v. 44, n. 4, p. 791-820, jul./ago, 2010.

MACHADO-DA-SILVA, C. L.; GONÇALVES, S. A. Nota técnica: A teoria institucional. In: CLEGG, S. Handbook de estudos organizacionais. São Paulo: Atlas, 1999.

MACHADO-DA-SILVA, Clóvis L.; FONSECA, Valéria Silva da; CRUBELLATE, João Marcelo. Estrutura, agência e interpretação: elementos para uma abordagem recursiva do processo de institucionalização. Revista de Administração Contemporânea, v. 9, n. 1, p. 939, 2005. 
MACHADO-DA-SILVA, Clóvis L.; FONSECA, Valéria Silva da. Competitividade organizacional: uma tentativa de reconstrução analítica. Organizações \& Sociedade, v. 4, n. 7, p. 97-114, 1996.

MAPURUNGA, Patrícia V. R.; MENESES, Anelise F. de; PETER, Maria da G. A. O processo de convergência das normas internacionais de contabilidade: uma realidade nos setores privado e público brasileiros. Revista Controle, v. 9, n. 1, p. 87-107, 2011.

MARCONI, Marina A.; LAKATOS, Eva M. Fundamentos de metodologia científica. In: Fundamentos de metodologia científica. Atlas, 2003.

MENDES, Gilmar F.; COELHO, Inocêncio M.; BRANCO, Paulo G. G. B. Curso de Direito Constitucional. 5ed. São Paulo: Saraiva, 2010.

MENEZES JÚNIOR, Cleiton B. et al. Processo de Convergência no Setor Público: Análise Comparativa entre os Padrões Contábeis da IFAC e do IASB. Seminários em

Administração - SEMEAD, XIX, 2016.

MEYER, John W.; ROWAN, Brian. Institutionalized organizations: Formal Structure as Myth and Ceremony. American journal of sociology, v. 83, n.2, p. 340-363, 1977.

MOLL, Jodie; BURNS, John; MAJOR, Maria. Institutional theory. In: em Hoque, Z. (Ed.), Methodological Issues in Accounting Research: Theories, Methods and Issues, p. 183-205, 2006.

MORAES, Alexandre. Direito Constitucional. São Paulo: Editora Atlas, 2010.

NASCIMENTO, Leonardo S. A Contabilidade Patrimonial Integral no Setor Público: os parâmetros, desafios e benefícios de sua implementação no Brasil. XIII Prêmio Do Tesouro Nacional, 2008.

NASCIMENTO, Leonardo S. A Reforma da Contabilidade Governamental Brasileira: a necessária revisão dos preceitos vigentes em face das demandas de informações e do esforço de harmonização nacional e internacional. Brasília: ESAF, 2007.

NETO, João Estevão Barbosa; COLAUTO, Romualdo Douglas. Teoria Institucional: estudo bibliométrico em anais de congressos e periódicos científicos. ConTexto, v. 10, n. 18, p. 6374, 2010.

NEVES, Wanderlei P. Prefácio. In: FEIJÓ, Paulo H.; RIBEIRO, Carlos E. Entendendo o Plano de Contas Aplicado ao Setor Público (PCASP). Brasília: Editora Gestão Pública. Brasília, 2014, Associação Brasileira de Editores Científicos de Psicologia; Instituto de Psicologia da Universidade de São Paulo, 2009. p. 13-15.

NIYAMA, Jorge Katsumi. Contabilidade Internacional. São Paulo: Atlas, 2009.

NIYAMA, Jorge Katsumi; SILVA, César Augusto Tibúrcio. Teoria da Contabilidade.

Editora Atlas, São Paulo, 2009. 
NOBES, Christopher; PARKER, Robert. Comparative International Accounting. Edinburgh: Pearson Education, 2008.

NORTH, Douglas C. Institutions, institutional change and economic performance. Cambridge University Press, 1990.

OUDA, Hassan A. G. Basic Requirements Model for Successful Application of Accrual Accounting in the Public Sector. Paper Presented at the 8th CIGAR Conference, Valencia University, Valencia, Spain, 14-15 jun. 2001.

OUDA, Hassan A. G. Basic requirements model for successful implementation of accrual accounting in the public sector. Public Fund Digest, v. 4, n. 1, p. 78-99, 2004.

OUDA, Hassan A. G. Transition barriers of accrual accounting in the public sector of developed and developing countries: statistical analyses with special focus on The Netherlands and Egypt. Implementing reforms in public sector accounting, p.111-137, 2008.

OUDA, Hassan A. G. A Prescriptive Model for Successful Transition to Accrual Accounting in the Government Sector. International Journal on Governmental Financial Management, v. 10, n. 1, 2010.

OULASVIRTA, Lasse. The reluctance of a developed country to choose International Public Sector Accounting Standards of the IFAC. A critical case study. Critical Perspectives on Accounting, v. 25, n. 3, p. 272-285, 2014.

PECI, Alketa. A nova teoria institucional em estudos organizacionais: uma abordagem crítica. Cadernos Ebape, v. 4, n. 1, 2006.

PEREIRO, Luis E. Valuation of companies in emerging markets: a practical approach. John Wiley \& Sons, 2002.

PÉREZ, Carmen C.; HERNANDEZ, Antonio L. Latin-American public financial reporting: recent and future development. Public Administration and Development, v. 27, n. 2, p. 139-157, 2007.

PINA, Vicente; TORRES, Lourdes; YETANO, Ana. Accrual accounting in EU local governments: One method, several approaches. European Accounting Review, v. 18, n. 4, p. 765-807, 2009.

POHLMANN, Marcelo C. Harmonização contábil no MERCOSUL: a profissão e o processo de emissão de normas- uma contribuição. Cad estud., São Paulo, n. 12, p. 01-19, 1995.

POTTER, Bradley N. Accounting as a Social and Institutional Practice: Perspectives to enrich our understanding of accounting change. Abacus, v. 41, n. 3, p. 265-289, 2005.

PREVITS, Gary J.; PARKER, Lee D.; COFFMAN, Edward N. An accounting historiography: subject matter and methodology. Abacus, v. 26, n. 2, p. 136-158, 1990. 
PRODANOV, Cleber C.; FREITAS, Ernani C. Metodologia do Trabalho Científico: Métodos e Técnicas da Pesquisa e do Trabalho Acadêmico, $2^{\mathbf{a}}$ Edição. Editora Feevale, 2013.

PWC. PricewaterhouseCoopers Global survey on accounting and reporting by central governments. Towards a new era in government accounting and reporting. 2ed, p. 1-46, 2015.

RADEBAUGH, Lee H.; GRAY, S. J.; BLACK, Ervin L. International accounting and multinational enterprises. 6th ed. Hoboken: Wiley, 2006.

RAUPP, Fabiano M.; BEUREN, Ilse M. Metodologia da pesquisa aplicável às ciências sociais. In: BEUREN, Ilse. Maria. (Org.). Como elaborar trabalhos monográficos em contabilidade: teoria e prática. São Paulo: Atlas, 2006.

REVOREDO, Márcia Maria Oliveira. Brasil rumo aos padrões internacionais de contabilidade para o setor público: uma análise sob a ótica do Financial Management Reform Process Model de Lüder. 2008. 170 f. Dissertação (Mestrado) - Universidade do Estado do Rio de Janeiro, Faculdade de Administração e Finanças.

RIBEIRO, Cintia de Melo Albuquerque; BIZERRA, André Luiz Villagelim. Convergência Contábil na Administração Pública Federal: o Caso das Instituições Federais de Ensino do Estado do Rio de Janeiro. Pensar Contábil, Rio de Janeiro, v. 13, n. 52, p. 55 - 64, set/dez. 2011.

ROYBARK, Helen M.; COFFMAN, Edward N.; PREVITS, Gary J. The First Quarter Century of the GASB (1984-2009): A Perspective on Standard Setting (Part One). Abacus, v. 48, n. 1, p. 1-30, 2012.

SCOTT, W. R. Institutions and organizations. Thousand Oaks, California: Sage, 2001.

SELZNICK, Philip. A liderança na administração: uma interpretação sociológica. Rio de Janeiro: FGV, 1972.

SILVA, Anderson C. et al. AVALIAÇÃO DE ATIVOS IMOBILIZADOS NO SETOR PÚBLICO: ESTUDO DE CASO EM UMA ORGANIZAÇÃO MILITAR DA MARINHA DO BRASIL. Revista de Informação Contábil, v. 6, n. 3, 2012.

SILVA, Júlio C. et al. O Impacto da Depreciação nos Índices Econômicos e Financeiros de uma Organização Pública pela Aplicação da Ipsas 17. Pensar Contábil, v. 16, n. 60, 2014.

SOARES, Maurélio; SCARPIN, Jorge E. A convergência da contabilidade pública nacional às normas internacionais e os impactos na aplicação da DRE na administração direta. Revista Catarinense da Ciência Contábil, v. 9, n. 27, p. 25-42, 2010.

SOEIRO, Tiago de Moura. Pesquisa institucional em contabilidade: uma revisão nos principais periódicos nacionais e internacionais. 2015. 145 f. Dissertação (Mestrado em Ciências Contábeis) - Universidade Federal de Pernambuco, CCSA. 
SUCHMAN, Mark C. Managing Legitimacy: Strategic and Institutional Approaches. Academy of Management Review, 20, p. 571-610, 1995.

SUTCLIFFE, Paul. The standards programme of IFAC's Public Sector Committee. Public Money \& Management, v. 23, n. 1, p. 29-36, 2003.

TCU. Tribunal de Contas da União. Acórdão nº 0158/2012. Disponível em: <http://www.tcu.gov.br/Consultas/Juris/Docs/judoc/Acord/20120206/AC_0158_03_12_P.doc >. Acesso em: 25 set. 2016.

. Tribunal de Contas da União. Acórdão no 1929/2012. Disponível em: <https://contas.tcu.gov.br/sagas/SvlVisualizarRelVotoAcRtf?codFiltro=SAGAS-SESSAOENCERRADA\&seOcultaPagina=S\&item0=404766>. Acesso em: 25 set. 2016.

TOLBERT, Pamela S.; ZUCKER, Lynne G. A institucionalização da teoria institucional. Handbook de estudos organizacionais, v. 1, p. 196-219, 1999.

VAN HENGEL, Hugo; BUDDING, Tjerk; GROOT, Tom. Loosely Coupled Results Control in Dutch Municipalities. Financial Accountability \& Management, v. 30, n. 1, p. 49-74, 2014.

VENTURA, Magda M. O estudo de caso como modalidade de pesquisa.Revista Socerj, v. 20, n. 5, p. 383-386, 2007.

VIANA, Clilson C. et al. Implantação da depreciação no setor público e procedimentos contábeis: um estudo em uma instituição pública de ensino superior. Revista

Contemporânea de Contabilidade, v. 10, n. 20, p. 113-138, 2013.

VICENTE, Ernesto F.R.; MORAIS, Leandro M.; PLATT NETO, Orion A. A reforma na contabilidade pública brasileira e o processo de convergência: Implicações e perspectivas. Revista de Informação Contábil, v. 6, n. 2, p. 01-20, 2012.

VILLEGAS, Mauricio G.; JULVE, Vicente M. Las innovaciones en contabilidad gubernamental en Latinoamérica: el caso de Colombia. Innovar, v. 22, n. 45, p. 17, 2012.

WEFFORT, Elionor F. J. O Brasil e a harmonização contábil internacional. São Paulo: Atlas, 2005.

YIN, Robert K. Estudo de Caso: Planejamento e Métodos. Editora Bookman, 2010.

ZEFF, Stephen A. Some obstacles to global financial reporting comparability and convergence at a high level of quality. The British Accounting Review, v. 39, n. 4, p. 290302, 2007.

ZUCKER, Lynne G. Institutional theories of organization. Annual Rewiew of Sociology, v. 13, p. 443-464, 1987. 


\section{APÊNDICE A - Roteiro Semiestruturado para Entrevistas}

\section{IDENTIFICAÇÃO DO ENTREVISTADO}

\begin{tabular}{|l|l|}
\hline Nome do entrevistado & \\
\hline Ator que representa & \\
\hline Função exercida pelo entrevistado no processo & \\
\hline Canal de comunicação & \\
\hline Data da entrevista & \\
\hline Duração & \\
\hline
\end{tabular}

\section{PERGUNTA CENTRAL}

1. Qual é o papel do ator que você representa no processo de convergência do setor público brasileiro aos padrões contábeis internacionais (IPSAS)?

\section{PERGUNTAS COMPLEMENTARES}

Descreva analiticamente, em sua percepção, as seguintes questões:

2. A trajetória da instituição (ator) desde o início do processo até os dias atuais (linha temporal), comentando eventuais mudanças (harmonização versus padronização, alteração de papéis dos promotores da reforma, etc.) durante esse período.

3. A motivação (por exemplo, necessidade de melhoria da informação, pressão externa, etc.) para a adoção das IPSAS.

4. Instituições/atores que têm contribuído para o processo ao longo dos anos (preferencialmente traçando uma linha temporal).

5. Papel que a instituição/ator tem exercido nesse processo (apenas consultivo, apenas como operador, normativo, fiscalizador, etc.).

6. Ações formais ou informais implementadas pela instituição/ator a partir desse papel (por exemplo, emissão de notícias, de orientações, desenvolvimento e oferecimento de seminários e cursos, etc.). 
7. Cronograma de planejamento/execução para implementação das IPSAS no País desde o início do processo (incluindo ações futuras).

8. Barreiras encontradas pela a instituição em um primeiro momento para a concretização das ações planejadas, e as que ainda estão sendo superadas.

9. Resultados obtidos pela instituição/ator com a relação à implementação das IPSAS a partir das ações já realizadas.

10. Resultados esperados pela instituição/ator com a relação à implementação das IPSAS a partir das ações já realizadas ou a realizar. 
APÊNDICE B - Entrevistados

\begin{tabular}{|l|l|}
\hline Nome do entrevistado & Leonardo Silveira do Nascimento \\
\hline Ator que representa & Secretaria do Tesouro Nacional - STN \\
\hline $\begin{array}{l}\text { Função exercida pelo } \\
\text { entrevistado no processo }\end{array}$ & $\begin{array}{l}\text { Membro do Grupo Assessor do CFC das Normas Brasileiras } \\
\text { de Contabilidade Aplicadas ao Setor Público, Coordenador- } \\
\text { Geral de Normas de Contabilidade Aplicadas à Federação da } \\
\text { STN e Representante do CFC no IPSASB/IFAC. }\end{array}$ \\
\hline Canal de comunicação & Pessoalmente \\
\hline Data da entrevista & $01 / 09 / 2016$ \\
\hline Duração & $1 \mathrm{~h} 29$ \\
\hline
\end{tabular}

\begin{tabular}{|l|l|}
\hline Nome do entrevistado & Joaquim Osório Liberalquino Ferreira \\
\hline Ator que representa & Conselho Federal de Contabilidade \\
\hline $\begin{array}{l}\text { Função exercida pelo } \\
\text { entrevistado no processo }\end{array}$ & $\begin{array}{l}\text { Membro do Grupo Assessor do CFC das Normas Brasileiras } \\
\text { de Contabilidade Aplicadas ao Setor Público }\end{array}$ \\
\hline Canal de comunicação & Telefone \\
\hline Data da entrevista & $19 / 08 / 2016$ \\
\hline Duração & $1 \mathrm{~h} 34$ \\
\hline
\end{tabular}

\begin{tabular}{|l|l|}
\hline Nome do entrevistado & Laércio Mendes Vieira \\
\hline Ator que representa & Tribunal de Contas da União - TCU \\
\hline $\begin{array}{l}\text { Função exercida pelo } \\
\text { entrevistado no processo }\end{array}$ & $\begin{array}{l}\text { Representante do TCU junto ao Grupo de Trabalho da } \\
\text { Convergência em Contabilidade Aplicada ao Setor Público } \\
\text { (GTCASP) do CFC }\end{array}$ \\
\hline Canal de comunicação & Pessoalmente \\
\hline Data da entrevista & $01 / 09 / 2016$ \\
\hline Duração & $1 \mathrm{~h} 28$ \\
\hline
\end{tabular}




\section{APÊNDICE C - Questionário}

Caro Participante,

Este questionário tem como objetivo analisar o processo de convergência da contabilidade pública brasileira aos padrões internacionais e analisar a influência dos atores envolvidos nesse processo. A presente coleta de dados destina-se a dar subsídios para a elaboração da dissertação da mestranda Raquel Luz de Lima, aluna do Programa de PósGraduação em Ciências Contábeis - PPGCONT da Universidade de Brasília, orientada pela professora Dra. Diana Vaz de Lima.

Salientamos que os dados do perfil do entrevistado por meio deste questionário serão sigilosos e confidenciais e, em hipótese alguma, os respondentes serão identificados na pesquisa.

\section{I - Perfil do Entrevistado}

1. Sexo:

( ) Feminino

( ) Masculino

\section{Faixa etária:}

( ) Até 25 anos

( ) 26 a 35 anos

( ) 36 a 45 anos

( ) 46 a 55 anos

( ) Acima de 55 anos

3. Escolaridade (Informar apenas se foi concluído. Se possuir mais de uma graduação ou pós-graduação, informar todas as áreas de formação):

( ) Nível Médio

( ) Técnico

( ) Graduação. Qual(is) área(s)?

( ) Especialização Lato Sensu. Qual(is) área(s)?

( ) Mestrado. Qual(is) área(s)?

( ) Doutorado. Qual(is) área(s)?

( ) Pós Doutorado. Qual(is) área(s)?

\section{4. Área de trabalho:}
( ) Setor Público
( ) Iniciativa Privada
( ) Terceiro Setor

5. Região de trabalho:
( ) Centro-Oeste
( ) Nordeste
( ) Norte
( ) Sudeste
( ) Sul

6. Esfera de Governo do setor público que você trabalha:
( ) Não trabalho no Setor Público
( ) Federal
( ) Estadual
( ) Municipal 
7. Esfera de Poder do setor público que você trabalha:

( ) Não trabalho no Setor Público

( ) Executivo

( ) Legislativo

( ) Judiciário

( ) Ministério Público

( ) Tribunal de Contas

8. Tempo de serviço público (considerar data de posse no serviço público):

9 - Tempo de experiência com a Contabilidade Aplicada ao Setor Público (em anos):

10. Participação em cursos, palestras e capacitações sobre a Contabilidade Aplicada ao Setor Público, independente da carga horária, desde de 2007:
( ) De 1 a 5
( ) De 6 a 10
( ) De 11 a 15
( ) Acima de 15

11. Entidade na qual você é vinculado:

( ) Associação Brasileira das Secretarias de Finanças das Capitais - ABRASF

( ) Associação Brasileira dos Municípios - ABM

( ) Associação dos Membros dos Tribunais de Contas do Brasil - ATRICON

( ) Confederação Nacional dos Municípios - CNM

( ) Conselho Federal de Contabilidade - CFC

( ) Conselho Nacional de Controle Interno - CONACI

( ) Consultoria de Orçamento e Fiscalização Financeira, da Câmara dos Deputados - CONOF

( ) Consultoria de Orçamentos, Fiscalização e Controle, do Senado Federal - CONORF

( ) Controladoria Geral da União - CGU

( ) Departamento dos Regimes de Previdência no Serviço Público - DRPSP/SPS/MPS

( ) Frente Nacional de Prefeitos - FNP

( ) Grupo dos Gestores de Finanças Estaduais - GEFIN

( ) Instituto Brasileiro de Geografia e Estatística - IBGE

( ) Instituto Rui Barbosa - IRB

( ) Secretaria de Orçamento Federal - SOF

( ) Secretaria do Tesouro Nacional - STN

( ) Tribunal de Contas da União - TCU

( ) Não sou vinculado a essas instituições. Entidade em que é vinculado?

12. Ano de participação no GTCON (Marcar todos os anos de participação): ( ) 2007 ( ) 2008 ( ) 2009 ( ) 2010 ( ) 2011 ( ) 2012 ( ) 2013 ( ) 2014 ( ) 2015 ( ) 2016

13. O Sr. (a Sra.) tem conhecimento de alguma ação (formal e/ou informal) realizada pela organização em que trabalha/atua relacionada à implementação das Normas de Contabilidade Aplicadas ao Setor Público?

$\square$ Não

$\square$ Sim. Quais ações foram realizadas (tanto formais como informais)? 


\section{II - Processo de Convergência no Brasil}

14. Em sua opinião, quais foram as principais razões que levaram o governo brasileiro a convergir às IPSAS?

15. Em sua opinião, quais são os principais efeitos e resultados que já podem ser observados na contabilidade pública brasileira e no seu ambiente, de forma geral, após o início do processo convergência?

16. Em sua opinião, está havendo dificuldades na implementação das Normas de Contabilidade Aplicadas ao Setor Público no país? Em caso positivo, quais?

$\underline{\text { III - Atores }}$

17. Em sua percepção, quais são os principais atores atuando na promoção e no direcionamento do processo de convergência das normas brasileiras de contabilidade às normas internacionais? 
18. Qual é o seu grau de percepção acerca dos seguintes itens:

\begin{tabular}{|l|l|l|l|l|l|}
\hline & $\begin{array}{l}\text { Muito } \\
\text { Baixo }\end{array}$ & Baixo & Médio & Alto & $\begin{array}{c}\text { Muito } \\
\text { Alto }\end{array}$ \\
\hline Apoio político e liderança técnica & & & & & \\
\hline $\begin{array}{l}\text { Interação entre os atores promotores e direcionadores } \\
\text { envolvidos no processo de convergência da contabilidade } \\
\text { pública brasileira }\end{array}$ & & & & & \\
\hline $\begin{array}{l}\text { Planejamento do processo de convergência e sua } \\
\text { implementação no país }\end{array}$ & & & & & \\
\hline Transparência na condução do processo de convergência & & & & & \\
\hline $\begin{array}{l}\text { Relação de Custo versus Benefício do processo de } \\
\text { convergência }\end{array}$ & & & & \\
\hline $\begin{array}{l}\text { Adequação do processo de convergência, como um todo, } \\
\text { considerando o cenário do país (Decisão de adoção ou } \\
\text { harmonização, forma como tem sido conduzido, etc.) }\end{array}$ & & & & & \\
\hline
\end{tabular}

19. Em sua opinião, qual o nível de influência prática dos atores promotores e direcionadores, a seguir listados, no processo de convergência da contabilidade pública e implantação das IPSAS?

\begin{tabular}{|l|l|l|l|l|l|}
\hline & $\begin{array}{c}\text { Muito } \\
\text { Baixo }\end{array}$ & Baixo & Médio & $\begin{array}{c}\text { Alto } \\
\text { Muito } \\
\text { Alto }\end{array}$ \\
\hline Academia (universidades) & & & & & \\
\hline Conselho Federal de Contabilidade (CFC) & & & & & \\
\hline Secretaria do Tesouro Nacional (STN) & & & & & \\
\hline Tribunal de Contas da União (TCU) & & & & & \\
\hline Tribunais de Contas (TCs) Estaduais e Municipais & & & & \\
\hline $\begin{array}{l}\text { Outros atores que contribuam para a promoção e direcionamento do } \\
\text { processo de convergência da contabilidade pública brasileira: }\end{array}$ & & & & & \\
\hline
\end{tabular}


20. Em sua opinião, havia necessidade de mudança nas normas de contabilidade pública?

( ) $\operatorname{Sim}$

( ) Não

21. Em sua opinião, dentre as ações já realizadas com vistas a implementação das IPSAS quais que mais impactaram na condução do processo de convergência da contabilidade pública brasileira?

Gostaria de realizar algum comentário adicional sobre o processo de convergência e atuação dos atores nesse processo?

Obrigada pela sua participação! 


\section{APÊNDICE C - Pedido de Acesso à Informação}

Gostaria de solicitar, para fins de pesquisa acadêmica (Dissertação de Mestrado do Programa de Ciências Contábeis da UnB), uma lista das ações realizadas pela instituição, relacionadas à convergência da contabilidade pública, desde o início do processo. Incluindo:

- Normativos emitidos (e respectivo documento, no caso de não serem disponibilizados na internet) e outros publicações (cartilhas, etc);

- Cooperações técnicas e parcerias realizadas (detalhar escopo e período, se possível indicação do documento);

- Atas de reuniões dos grupos de trabalho (normativos de estrutura e composição);

- Cursos, palestras e capacitações, informando o período em que ocorreu e se realizado apenas pela instituição ou mediante parceria.

- Outros. 


\section{ANEXO A - Adoção das IPSAS: Resumo das Jurisdições que já Adotaram ou estão em Processo de Adoção}

\begin{tabular}{|c|c|c|}
\hline Nível de governo & Status da adoção & Tipo de norma \\
\hline \multicolumn{3}{|l|}{ Argentina } \\
\hline Incerto & Planejado & $\begin{array}{l}\text { Normas nacionais baseadas nas IPSAS } \\
\text { por competência }\end{array}$ \\
\hline \multicolumn{3}{|l|}{ Armênia } \\
\hline Incerto & Em andamento & $\begin{array}{l}\text { Normas nacionais baseadas nas IPSAS } \\
\text { por competência }\end{array}$ \\
\hline \multicolumn{3}{|l|}{ Austrália } \\
\hline Locais/Municipais & Adotado & $\begin{array}{l}\text { Padrões Nacionais semelhantes às IPSAS } \\
\text { por competência }\end{array}$ \\
\hline Estado/Província & Adotado & $\begin{array}{l}\text { Padrões Nacionais semelhantes às IPSAS } \\
\text { por competência }\end{array}$ \\
\hline Central/Nacional/Federal & Adotado & $\begin{array}{l}\text { Padrões Nacionais semelhantes às IPSAS } \\
\text { por competência }\end{array}$ \\
\hline \multicolumn{3}{|l|}{ Áustria } \\
\hline Central/Nacional/Federal & Adotado & IPSAS por competência \\
\hline Estado/província & Em andamento & IPSAS por competência \\
\hline \multicolumn{3}{|l|}{ República de Azerbaijão } \\
\hline Incerto & Em andamento & $\begin{array}{l}\text { Normas nacionais baseadas nas IPSAS } \\
\text { por competência }\end{array}$ \\
\hline \multicolumn{3}{|l|}{ Bangladesh } \\
\hline Incerto & Em andamento & IPSAS por competência \\
\hline \multicolumn{3}{|l|}{ Barbados } \\
\hline Incerto & Em andamento & IPSAS por competência \\
\hline \multicolumn{3}{|l|}{ Bélgica } \\
\hline Incerto & Em andamento & $\begin{array}{l}\text { Normas nacionais baseadas nas IPSAS } \\
\text { por competência }\end{array}$ \\
\hline \multicolumn{3}{|l|}{ Bolívia } \\
\hline Incerto & Adotado & IPSAS por competência \\
\hline \multicolumn{3}{|l|}{ Bósnia e Herzegovina } \\
\hline Incerto & Adotado & Consistente com as normas nacionais \\
\hline \multicolumn{3}{|l|}{ Botswana } \\
\hline Incerto & Planejado & IPSAS por competência \\
\hline \multicolumn{3}{|l|}{ Brasil } \\
\hline Estado/província & Em andamento & IPSAS por competência \\
\hline Locais/municipais & Em andamento & IPSAS por competência \\
\hline Central/Nacional/Federal & Em andamento & IPSAS por competência \\
\hline \multicolumn{3}{|l|}{ Camboja } \\
\hline Incerto & Em andamento & IPSAS por competência \\
\hline \multicolumn{3}{|l|}{ Canadá } \\
\hline Central/Nacional/Federal & Adotado & $\begin{array}{l}\text { Padrões Nacionais semelhantes às IPSAS } \\
\text { por competência }\end{array}$ \\
\hline Estado/província & Adotado & $\begin{array}{l}\text { Padrões Nacionais semelhantes às IPSAS } \\
\text { por competência }\end{array}$ \\
\hline
\end{tabular}




\begin{tabular}{|c|c|c|}
\hline Nível de governo & Status da adoção & Tipo de norma \\
\hline Locais/municipais & Adotado & $\begin{array}{l}\text { Padrões Nacionais semelhantes às IPSAS } \\
\text { por competência }\end{array}$ \\
\hline \multicolumn{3}{|l|}{ Ilhas Cayman } \\
\hline Central/Nacional/Federal & Em andamento & IPSAS por competência \\
\hline \multicolumn{3}{|l|}{ Chile } \\
\hline Central/Nacional/Federal & Em andamento & IPSAS por competência \\
\hline Locais/municipais & Em andamento & IPSAS por competência \\
\hline \multicolumn{3}{|l|}{ China } \\
\hline Estado/província & Em andamento & $\begin{array}{l}\text { Padrões Nacionais semelhantes às IPSAS } \\
\text { por competência IPSAS }\end{array}$ \\
\hline Central/Nacional/Federal & Planejado & $\begin{array}{l}\text { Padrões Nacionais semelhantes às IPSAS } \\
\text { por competência }\end{array}$ \\
\hline \multicolumn{3}{|l|}{ Costa Rica } \\
\hline Central/Nacional/Federal & Em andamento & IPSAS por competência \\
\hline \multicolumn{3}{|l|}{ República Dominicana } \\
\hline Incerto & Planejado & $\begin{array}{l}\text { Normas nacionais baseadas nas IPSAS } \\
\text { por competência }\end{array}$ \\
\hline \multicolumn{3}{|l|}{ Estônia } \\
\hline Incerto & Adotado & IPSAS por competência \\
\hline \multicolumn{3}{|l|}{ França } \\
\hline Central/Nacional/Federal & Adotado & $\begin{array}{l}\text { Padrões Nacionais semelhantes às IPSAS } \\
\text { por competência }\end{array}$ \\
\hline Locais/municipais & Adotado & $\begin{array}{l}\text { Padrões Nacionais semelhantes às IPSAS } \\
\text { por competência }\end{array}$ \\
\hline Fundos de segurança social & Adotado & $\begin{array}{l}\text { Padrões Nacionais semelhantes às IPSAS } \\
\text { por competência }\end{array}$ \\
\hline \multicolumn{3}{|l|}{ Gana } \\
\hline Incerto & Em andamento & IPSAS por competência \\
\hline \multicolumn{3}{|l|}{ Grécia } \\
\hline Todos & $\begin{array}{l}\text { Não tem planos } \\
\text { de mudança }\end{array}$ & $\begin{array}{l}\text { Padrões Nacionais semelhantes às IPSAS } \\
\text { por competência }\end{array}$ \\
\hline \multicolumn{3}{|l|}{ Guatemala } \\
\hline Central/Nacional/Federal & Em andamento & IPSAS por competência \\
\hline \multicolumn{3}{|l|}{ Honduras } \\
\hline Incerto & Em andamento & $\begin{array}{l}\text { Normas nacionais baseadas nas IPSAS } \\
\text { por competência }\end{array}$ \\
\hline \multicolumn{3}{|l|}{ Indonésia } \\
\hline Incerto & Em andamento & $\begin{array}{l}\text { Normas nacionais baseadas nas IPSAS } \\
\text { por competência }\end{array}$ \\
\hline \multicolumn{3}{|l|}{ Israel } \\
\hline Central/Nacional/Federal & Adotado & $\begin{array}{l}\text { Padrões Nacionais semelhantes às IPSAS } \\
\text { por competência }\end{array}$ \\
\hline \multicolumn{3}{|l|}{ Jamaica } \\
\hline Todos & Em andamento & IPSAS por competência \\
\hline \multicolumn{3}{|l|}{ Japão } \\
\hline Central/Nacional/Federal & Adotado & $\begin{array}{l}\text { Padrões nacionais consistentes com as } \\
\text { IPSAS por competência }\end{array}$ \\
\hline Jordânia & & \\
\hline
\end{tabular}




\begin{tabular}{|c|c|c|}
\hline Nível de governo & Status da adoção & Tipo de norma \\
\hline Todos & Em andamento & IPSAS por competência \\
\hline \multicolumn{3}{|l|}{ Cazaquistão } \\
\hline Incerto & Adotado & IPSAS por competência \\
\hline \multicolumn{3}{|l|}{ Quênia } \\
\hline Locais/municipais & Adotado & IPSAS por competência \\
\hline Central/Nacional/Federal & Em andamento & IPSAS por competência \\
\hline \multicolumn{3}{|l|}{ Coréia } \\
\hline Incerto & Em andamento & $\begin{array}{l}\text { Normas nacionais baseadas nas IPSAS } \\
\text { por competência }\end{array}$ \\
\hline \multicolumn{3}{|l|}{ Kuaite } \\
\hline Incerto & Em andamento & IPSAS por competência \\
\hline \multicolumn{3}{|l|}{ Quirguistão } \\
\hline Incerto & Planejado & IPSAS por competência \\
\hline \multicolumn{3}{|l|}{ Letônia } \\
\hline Central/Nacional/Federal & Adotado & IPSAS por competência \\
\hline Locais/municipais & Adotado & IPSAS por competência \\
\hline \multicolumn{3}{|l|}{ Lesoto } \\
\hline Incerto & Planejado & IPSAS por competência \\
\hline \multicolumn{3}{|l|}{ Libéria } \\
\hline Incerto & Em andamento & IPSAS por competência \\
\hline \multicolumn{3}{|l|}{ Lituânia } \\
\hline Central/Nacional/Federal & Adotado & IPSAS por competência \\
\hline Locais/municipais & Adotado & IPSAS por competência \\
\hline \multicolumn{3}{|l|}{$\begin{array}{l}\text { Macedónia (nota usa tanto caixa e } \\
\text { competência IPSAS) }\end{array}$} \\
\hline Outros & Adotado & IPSAS por competência \\
\hline \multicolumn{3}{|l|}{ Madagascar } \\
\hline Incerto & Adotado & $\begin{array}{l}\text { Normas nacionais baseadas nas IPSAS } \\
\text { por competência }\end{array}$ \\
\hline \multicolumn{3}{|l|}{ Malásia } \\
\hline Central/Nacional/Federal & Em andamento & IPSAS por competência \\
\hline \multicolumn{3}{|l|}{ Malta } \\
\hline Locais/municipais & Adotado & $\begin{array}{l}\text { Padrões Nacionais semelhantes às IPSAS } \\
\text { por competência }\end{array}$ \\
\hline Central/Nacional/Federal & Em andamento & IPSAS por competência \\
\hline \multicolumn{3}{|l|}{ México } \\
\hline Estado/província & Adotado & Consistente com as normas nacionais \\
\hline Central/Nacional/Federal & Adotado & Consistente com as normas nacionais \\
\hline Locais/municipais & Adotado & Consistente com as normas nacionais \\
\hline \multicolumn{3}{|l|}{ Mongólia } \\
\hline Incerto & Adotado & IPSAS por competência \\
\hline \multicolumn{3}{|l|}{ Nova Zelândia } \\
\hline Todos os & Adotado & $\begin{array}{l}\text { Normas nacionais baseadas nas IPSAS } \\
\text { por competência }\end{array}$ \\
\hline Paquistão & & \\
\hline
\end{tabular}




\begin{tabular}{|c|c|c|}
\hline Nível de governo & Status da adoção & Tipo de norma \\
\hline Incerto & Planejado & IPSAS por competência \\
\hline \multicolumn{3}{|l|}{ Panamá } \\
\hline Incerto & Em andamento & IPSAS por competência \\
\hline \multicolumn{3}{|l|}{ Peru } \\
\hline Incerto & Adotado & IPSAS por competência \\
\hline \multicolumn{3}{|l|}{ Filipinas } \\
\hline Incerto & Adotado & IPSAS por competência \\
\hline \multicolumn{3}{|l|}{ Polônia } \\
\hline Incerto & Planejado & IPSAS por competência \\
\hline \multicolumn{3}{|l|}{ Portugal } \\
\hline Incerto & Planejado & IPSAS por competência \\
\hline \multicolumn{3}{|l|}{ Rússia } \\
\hline Central/Nacional/Federal & Em andamento & IPSAS por competência \\
\hline Estado/província & Em andamento & IPSAS por competência \\
\hline Locais/municipais & Em andamento & IPSAS por competência \\
\hline \multicolumn{3}{|l|}{ Cingapura } \\
\hline Central/Nacional/Federal & $\begin{array}{l}\text { Não tem planos } \\
\text { de mudança }\end{array}$ & $\begin{array}{l}\text { Padrões Nacionais semelhantes às IPSAS } \\
\text { por competência }\end{array}$ \\
\hline \multicolumn{3}{|l|}{ Eslováquia } \\
\hline Locais/municipais & Adotado & IPSAS por competência \\
\hline Central/Nacional/Federal & Adotado & IPSAS por competência \\
\hline \multicolumn{3}{|l|}{ Eslovênia } \\
\hline Central/Nacional/Federal & Planejado & IPSAS por competência \\
\hline Locais/municipais & Planejado & IPSAS por competência \\
\hline \multicolumn{3}{|l|}{ África do Sul } \\
\hline Locais/municipais & Adotado & Normas nacionais baseadas nas IPSAS \\
\hline Estado/província & Adotado & Normas nacionais baseadas nas IPSAS \\
\hline Central/Nacional/Federal & Adotado & Normas nacionais baseadas nas IPSAS \\
\hline \multicolumn{3}{|l|}{ Espanha } \\
\hline Incerto & Em andamento & IPSAS por competência \\
\hline \multicolumn{3}{|l|}{ Sri Lanka } \\
\hline Incerto & Planejado & $\begin{array}{l}\text { Padrões Nacionais semelhantes às IPSAS } \\
\text { por competência }\end{array}$ \\
\hline \multicolumn{3}{|l|}{ Suécia } \\
\hline Central/Nacional/Federal & Adotado & $\begin{array}{l}\text { Padrões Nacionais semelhantes às IPSAS } \\
\text { por competência }\end{array}$ \\
\hline Locais/municipais & Adotado & $\begin{array}{l}\text { Padrões Nacionais semelhantes às IPSAS } \\
\text { por competência }\end{array}$ \\
\hline \multicolumn{3}{|l|}{ Suíça } \\
\hline Central/Nacional/Federal & Adotado & IPSAS por competência \\
\hline \multicolumn{3}{|l|}{ Tajiquistão } \\
\hline Incerto & Adotado & $\begin{array}{l}\text { Padrões Nacionais semelhantes às IPSAS } \\
\text { por competência }\end{array}$ \\
\hline \multicolumn{3}{|l|}{ Tanzânia } \\
\hline Locais/municipais & Adotado & IPSAS por competência \\
\hline
\end{tabular}




\begin{tabular}{|c|c|c|}
\hline Nível de governo & Status da adoção & Tipo de norma \\
\hline Central/Nacional/Federal & Em andamento & IPSAS por competência \\
\hline \multicolumn{3}{|l|}{ Turquia } \\
\hline Locais/municipais & Em andamento & IPSAS por competência \\
\hline Central/Nacional/Federal & Em andamento & IPSAS por competência \\
\hline \multicolumn{3}{|l|}{ Turcomenistão } \\
\hline Incerto & Adotado & IPSAS por competência \\
\hline \multicolumn{3}{|l|}{ Uganda } \\
\hline Incerto & Planejado & IPSAS por competência \\
\hline \multicolumn{3}{|l|}{ Ucrânia } \\
\hline Incerto & Em andamento & IPSAS por competência \\
\hline \multicolumn{3}{|l|}{ Emirados Árabes Unidos } \\
\hline Incerto & Em andamento & IPSAS por competência \\
\hline \multicolumn{3}{|l|}{ Reino Unido } \\
\hline Central/Nacional/Federal & Adotado & $\begin{array}{l}\text { Padrões Nacionais semelhantes às IPSAS } \\
\text { por competência }\end{array}$ \\
\hline Locais/municipais & Adotado & $\begin{array}{l}\text { Padrões Nacionais semelhantes às IPSAS } \\
\text { por competência }\end{array}$ \\
\hline \multicolumn{3}{|l|}{ Estados Unidos } \\
\hline Locais/municipais & Adotado & $\begin{array}{l}\text { Padrões Nacionais semelhantes às IPSAS } \\
\text { por competência }\end{array}$ \\
\hline Estado/província & Adotado & $\begin{array}{l}\text { Padrões Nacionais semelhantes às IPSAS } \\
\text { por competência }\end{array}$ \\
\hline Central/Nacional/Federal & Adotado & $\begin{array}{l}\text { Padrões Nacionais semelhantes às IPSAS } \\
\text { por competência }\end{array}$ \\
\hline \multicolumn{3}{|l|}{ Uzbequistão } \\
\hline Incerto & Planejado & IPSAS por competência \\
\hline \multicolumn{3}{|l|}{ Vanuatu } \\
\hline Todos & Em andamento & IPSAS por competência \\
\hline \multicolumn{3}{|l|}{ Cidade do Vaticano } \\
\hline Todos & Em andamento & IPSAS por competência \\
\hline \multicolumn{3}{|l|}{ Afeganistão } \\
\hline Incerto & Em andamento & IPSAS por caixa \\
\hline \multicolumn{3}{|l|}{ Albânia } \\
\hline Incerto & Planejado & IPSAS por caixa \\
\hline \multicolumn{3}{|l|}{ Butão } \\
\hline Incerto & Planejado & IPSAS por caixa \\
\hline \multicolumn{3}{|l|}{ Chipre } \\
\hline Incerto & Adotado & IPSAS por caixa \\
\hline \multicolumn{3}{|l|}{ Timor-Leste } \\
\hline Incerto & Adotado & IPSAS por caixa \\
\hline \multicolumn{3}{|l|}{ Fiji } \\
\hline Incerto & Adotado & IPSAS por caixa \\
\hline \multicolumn{3}{|l|}{ Gâmbia } \\
\hline Incerto & Em andamento & IPSAS por caixa \\
\hline Geórgia & & \\
\hline
\end{tabular}




\begin{tabular}{|c|c|c|}
\hline Nível de governo & Status da adoção & Tipo de norma \\
\hline Estado/província & Em andamento & IPSAS por caixa \\
\hline Central/Nacional/Federal & Em andamento & IPSAS por caixa \\
\hline \multicolumn{3}{|l|}{ Kosovo } \\
\hline Todos os & Adotado & IPSAS por caixa \\
\hline \multicolumn{3}{|l|}{ Laos } \\
\hline Todos os & Planejado & IPSAS por caixa \\
\hline \multicolumn{3}{|l|}{$\begin{array}{l}\text { Macedônia (nota: usa tanto IPSAS por } \\
\text { caixa como competência) }\end{array}$} \\
\hline Incerto & Em andamento & IPSAS por caixa \\
\hline \multicolumn{3}{|l|}{ Malawi } \\
\hline Incerto & Adotado & IPSAS por caixa \\
\hline \multicolumn{3}{|l|}{ Maldives } \\
\hline Incerto & Planejado & IPSAS por caixa \\
\hline \multicolumn{3}{|l|}{ Nepal } \\
\hline Todos os & Planejado & IPSAS por caixa \\
\hline \multicolumn{3}{|l|}{ Nicarágua } \\
\hline Incerto & Adotado & IPSAS por caixa \\
\hline \multicolumn{3}{|l|}{ Nigéria } \\
\hline Incerto & Em andamento & IPSAS por caixa \\
\hline \multicolumn{3}{|l|}{ Papua-Nova Guiné } \\
\hline Incerto & Adotado & IPSAS por caixa \\
\hline \multicolumn{3}{|l|}{ Sérvia e Montenegro } \\
\hline Incerto & Adotado & IPSAS por caixa \\
\hline \multicolumn{3}{|l|}{ Seychelles } \\
\hline Incerto & Em andamento & IPSAS por caixa \\
\hline \multicolumn{3}{|l|}{ Ilhas Salomão } \\
\hline Todos os & Adotado & IPSAS por caixa \\
\hline \multicolumn{3}{|l|}{ Tailândia } \\
\hline Incerto & Planejado & $\begin{array}{l}\text { Normas nacionais semelhantes às IPSAS } \\
\text { por caixa }\end{array}$ \\
\hline \multicolumn{3}{|l|}{ Iêmen } \\
\hline Incerto & Em andamento & IPSAS por caixa \\
\hline \multicolumn{3}{|l|}{ Zâmbia } \\
\hline Incerto & Em andamento & IPSAS por caixa \\
\hline \multicolumn{3}{|l|}{ Zimbábue } \\
\hline Incerto & Planejado & IPSAS por caixa \\
\hline
\end{tabular}

Fonte: IPSASB, adaptado (2016). 


\section{ANEXO B - Portarias CFC relacionadas à Grupos na área de Contabilidade Pública}

\begin{tabular}{|c|c|c|}
\hline Portaria & Objeto & Integrantes \\
\hline $11 / 1998$ & $\begin{array}{l}\text { Cria Grupo de Estudo sobre Normas } \\
\text { Brasileiras de Contabilidade visando } \\
\text { a Área Pública }\end{array}$ & $\begin{array}{l}\text { Bolanger José de Almeida, Heraldo da Costa Reis, Lino } \\
\text { Martins da Silva, Marcos Vinícius Mendes Bastos e Ynel } \\
\text { de Carmargo. }\end{array}$ \\
\hline $12 / 2000$ & $\begin{array}{l}\text { Cria Grupo de Estudo sobre as } \\
\text { Normas Brasileiras de Contabilidade } \\
\text { voltado para a Área Pública }\end{array}$ & $\begin{array}{l}\text { Acy Castrillon Ferreira; Heraldo da Costa Reis; Lino } \\
\text { Martins da Silva; Marcos Vinicius Mendes Bastos, Ynel } \\
\text { de Carmargo. }\end{array}$ \\
\hline $35 / 2002$ & $\begin{array}{l}\text { Designa a composição e o } \text { a } \\
\text { funcionamento do Grupo de Estudo } \\
\text { voltado para a Área Pública }\end{array}$ & $\begin{array}{l}\text { José Antonio de Godoy; Acy Castrillon Ferreira; Heraldo } \\
\text { da Costa Reis; José Monteiro Alves; Lino Martins da } \\
\text { Silva; Maércio José Ceregatti; Marcos Vinicius Mendes } \\
\text { Bastos; Zulmir Ivânio Breda }\end{array}$ \\
\hline $37 / 2004$ & $\begin{array}{l}\text { Designa a composição e e o } \\
\text { funcionamento do Grupo de Estudo } \\
\text { voltado para a Área Pública }\end{array}$ & $\begin{array}{l}\text { Isaltino Alves da Cruz; Acy Castrillon Ferreira; Heraldo } \\
\text { da Costa Reis; Joaquim Osório Liberalquino Ferreira; } \\
\text { Lino Martins da Silva; Wander Luiz; Zulmir Ivânio } \\
\text { Breda }\end{array}$ \\
\hline $83 / 2004$ & $\begin{array}{l}\text { Cria Grupo de Trabalho para Revisar } \\
\text { a Lei 4.320/64 e Nomeia seus } \\
\text { Integrantes }\end{array}$ & $\begin{array}{l}\text { Inaldo da Paixão Santos Araújo, Isaltino Alves da Cruz, } \\
\text { Maria da Conceição Barros de Rezende, Ricardo } \\
\text { Portezan, Domingos Poubel de Castro e Wander Luiz }\end{array}$ \\
\hline $38 / 05$ & $\begin{array}{l}\text { Designa a composição e } \text { e } \\
\text { funcionamento do Grupo de Estudo } \\
\text { voltado para a Área Pública }\end{array}$ & $\begin{array}{l}\text { Isaltino Alves da Cruz, Acy Castrillon, Diana Vaz de } \\
\text { Lima, Heraldo da Costa Reis, Joaquim Osório } \\
\text { Liberalquino, Lino Martins da Silva e Zulmir Ivânio } \\
\text { Breda. }\end{array}$ \\
\hline $57 / 06$ & $\begin{array}{l}\text { Designa relatores para a NBC T } 16- \\
\text { Aspectos Contábeis Específicos da } \\
\text { Gestão Governamental. }\end{array}$ & $\begin{array}{l}\text { Joaquim Osório Liberalquino Ferreira e Lino Martins da } \\
\text { Silva }\end{array}$ \\
\hline $119 / 06$ & $\begin{array}{l}\text { Designa revisor para a NBC T } 16.1- \\
\text { Conceituação e Objetivos dos } \\
\text { Aspectos Contábeis Específicos da } \\
\text { Gestão Governamental. }\end{array}$ & Francisco José dos Santos Alves \\
\hline $120 / 06$ & $\begin{array}{l}\text { Designa revisor para a NBC T } 16.3- \\
\text { Planejamento e seus Instrumentos } \\
\text { dos Aspectos Contábeis Específicos } \\
\text { da Gestão Governamental. }\end{array}$ & Zulmir Ivânio Breda \\
\hline $121 / 06$ & $\begin{array}{l}\text { Designa revisor para a NBC T } 16.4- \\
\text { Transações Governamentais dos } \\
\text { Aspectos Contábeis Específicos da } \\
\text { Gestão Governamental. }\end{array}$ & João Eudes Bezerra Filho \\
\hline $122 / 06$ & $\begin{array}{l}\text { Designa relator para a NBC T } 16.8- \\
\text { Controle Interno dos Aspectos } \\
\text { Contábeis Específicos da Gestão } \\
\text { Governamental. }\end{array}$ & Blênio Severo Peixe \\
\hline $124 / 06$ & $\begin{array}{l}\text { Designa revisor para a NBC T } 16.5- \\
\text { Registro Contábil, NBC T } 16.6- \\
\text { Demonstrações Contábeis e NBC T } \\
16.7 \quad \text { Consolidação das } \\
\text { Demonstrações Contábeis dos } \\
\text { Aspectos Contábeis Específicos da } \\
\text { Gestão Governamental. }\end{array}$ & Heraldo da Costa Reis \\
\hline 134/06 & $\begin{array}{l}\text { Designa revisor para a NBC T } 16.2- \\
\text { Patrimônio e Sistemas Contábeis dos } \\
\text { Aspectos Contábeis Específicos da } \\
\text { Gestão Governamental. }\end{array}$ & Flávio da Cruz \\
\hline
\end{tabular}




\begin{tabular}{|c|c|c|}
\hline $136 / 06$ & $\begin{array}{l}\text { Designa relatora para a NBC T } 16.5 \\
\text { - Registro Contábil dos Aspectos } \\
\text { Contábeis Específicos da Gestão } \\
\text { Governamental. }\end{array}$ & Diana Vaz de Lima \\
\hline $137 / 06$ & $\begin{array}{l}\text { Designa relator para a NBC T } 16.6- \\
\text { Demonstrações Contábeis dos } \\
\text { Aspectos Contábeis Específicos da } \\
\text { Gestão Governamental. }\end{array}$ & Valmor Slomsky \\
\hline $138 / 06$ & 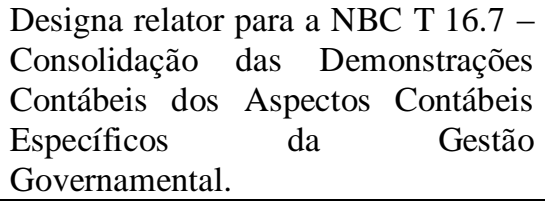 & José Francisco Ribeiro Filho \\
\hline $139 / 06$ & $\begin{array}{l}\text { Designa relator/coordenador para a } \\
\text { NBC T } 16.9-\text { Reavaliação e } \\
\text { Depreciação dos Bens Públicos dos } \\
\text { Aspectos Contábeis Específicos da } \\
\text { Gestão Governamental. }\end{array}$ & Antonio César Lins Cavalcanti \\
\hline $13 / 2010$ & $\begin{array}{l}\text { Institui o Grupo de Estudo das } \\
\text { Normas Brasileiras de Contabilidade } \\
\text { Técnicas do Setor Público }\end{array}$ & $\begin{array}{l}\text { Diana Vaz de Lima; Domingos Poubel de Castro; Inaldo } \\
\text { da Paixão Santos Araújo; João Eudes Bezerra Filho, } \\
\text { Joaquim Osório Liberalquino Ferreira; José Francisco } \\
\text { Ribeiro Filho; Lino Martins da Silva; Luiz Mário Vieira; } \\
\text { Paulo Henrique Feijó da Silva; Sandra Maria de } \\
\text { Carvalho Campos e Verônica Cunha de Souto Maior. }\end{array}$ \\
\hline $55 / 2010$ & $\begin{array}{l}\text { Altera os integrantes do Grupo de } \\
\text { Estudo expresso na Portaria } 13 / 2010 \\
\text { que dispõe sobre o Grupo de Estudo } \\
\text { das Normas Brasileiras de } \\
\text { Contabilidade Técnica do Setor } \\
\text { Público }\end{array}$ & $\begin{array}{l}\text { Diana Vaz de Lima; Domingos Poubel de Castro; Inaldo } \\
\text { da Paixão Santos Araújo; João Eudes Bezerra Filho; } \\
\text { Joaquim Osório Liberalquino Ferreira; José Francisco } \\
\text { Ribeiro Filho; Lino Martins da Silva; Luiz Mário Vieira; } \\
\text { Paulo Henrique Feijó da Silva; Sandra Maria de } \\
\text { Carvalho Campos; Verônica Cunha de Souto Maior; } \\
\text { Victor Branco de Holanda. }\end{array}$ \\
\hline $82 / 2010$ & $\begin{array}{l}\text { Institui Grupo de } \\
\text { Trabalho da } \\
\text { Convergência em Contabilidade } \\
\text { Pública (GTCP), previsto no } \\
\text { Regimento Interno do Comitê Gestor } \\
\text { da Convergência no Brasil }\end{array}$ & $\begin{array}{l}\text { José Francisco Ribeiro Filho, Valmor Slomski; Paulo } \\
\text { Henrique Feijó da Silva; Laércio Mendes Vieira; Victor } \\
\text { Branco de Holanda. }\end{array}$ \\
\hline $26 / 2011$ & $\begin{array}{l}\text { Institui Grupo de Estudos das } \\
\text { Normas Brasileiras de Contabilidade } \\
\text { Técnica do Setor Público }\end{array}$ & $\begin{array}{l}\text { Verônica Cunha de Souto Maior; Joaquim Osório } \\
\text { Liberalquino; Diana Vaz de Lima; Domingos Poubel de } \\
\text { Castro; Inaldo da Paixão Santos Araújo; João Eudes } \\
\text { Bezerra Filho; Lino Martins da Silva; Luiz Mário Vieira; } \\
\text { Nelson Machado; Paulo Henrique Feijó da Silva; Sandra } \\
\text { Maria de Carvalho Campos; Victor Branco de Holanda. }\end{array}$ \\
\hline $027 / 2012$ & $\begin{array}{l}\text { Institui Grupo Assessor das Normas } \\
\text { Brasileiras de Contabilidade } \\
\text { Aplicadas ao Setor Público }\end{array}$ & $\begin{array}{l}\text { Verônica Cunha de Souto Maior, Joaquim Osório } \\
\text { Liberalquino Ferreira, Diana Vaz de Lima, Inaldo da } \\
\text { Paixão Santos Araujo, João Eudes Bezerra Filho, Lino } \\
\text { Martins da Silva, Luiz Mário Vieira, Nelson Machado, } \\
\text { Paulo Henrique Feijó da Silva, Sandra Maria de } \\
\text { Carvalho Campos, Victor Branco de Holanda, Carlos } \\
\text { Alberto Miranda Medeiros, Valmor Slomski e Laércio } \\
\text { Mendes Vieira. }\end{array}$ \\
\hline $015 / 2013$ & $\begin{array}{l}\text { Institui Grupo Assessor das Normas } \\
\text { Brasileiras de Contabilidade } \\
\text { Aplicadas ao Setor Público }\end{array}$ & $\begin{array}{l}\text { Verônica Cunha de Souto Maior, Joaquim Osório } \\
\text { Liberalquino Ferreira, Diana Vaz de Lima, Inaldo da } \\
\text { Paixão Santos Araujo, João Eudes Bezerra Filho, Lino } \\
\text { Martins da Silva, Luiz Mário Vieira, Nelson Machado, } \\
\text { Paulo Henrique Feijó da Silva, Sandra Maria de } \\
\text { Carvalho Campos, Victor Branco de Holanda, Carlos } \\
\text { Alberto Miranda Medeiros, Laércio Mendes Vieira, } \\
\text { Alessandro Aurélio Caldeira, Renato Lima Cavalcante, } \\
\text { Gilvan da Silva Dantas, Renato Pontes Dias, Leonardo }\end{array}$ \\
\hline
\end{tabular}




\begin{tabular}{|c|c|c|}
\hline & & Silveira do Nascimento e Luiz Genédio Mendes Jorge. \\
\hline $103 / 14$ & $\begin{array}{l}\text { Institui Grupo Assessor das Normas } \\
\text { Brasileiras de Contabilidade } \\
\text { Aplicadas ao Setor Público }\end{array}$ & $\begin{array}{l}\text { Verônica Cunha de Souto Maior, Joaquim Osório } \\
\text { Liberalquino Ferreira, Juarez Domingues Carneiro, } \\
\text { Nelson Machado, Diana Vaz de Lima, João Eudes } \\
\text { Bezerra Filho, Luiz Mário Vieira, Sandra Maria de } \\
\text { Carvalho Campos, Victor Branco de Holanda, Carlos } \\
\text { Alberto Miranda Medeiros, Alessandro Aurélio Caldeira, } \\
\text { Gilvan da Silva Dantas, Renato Pontes Dias, Leonardo } \\
\text { Silveira do Nascimento, Rosilene Oliveira de Souza, } \\
\text { Michele Patrícia Roncálio, José Alexandre Magrini } \\
\text { Pigatto, Maria da Conceição Barros de Rezende e Inaldo } \\
\text { da Paixão Santos Araújo. }\end{array}$ \\
\hline $112 / 15$ & $\begin{array}{l}\text { Institui Grupo Assessor das Normas } \\
\text { Brasileiras de Contabilidade } \\
\text { Aplicadas ao Setor Público }\end{array}$ & $\begin{array}{l}\text { Verônica Cunha de Souto Maior, Gildernora Batista } \\
\text { Dantas Milhomem, Leonardo Silveira do Nascimento, } \\
\text { Joaquim Osório Liberalquino Ferreira, José Alexandre } \\
\text { Magrini Pigatto, Renato Pontes Dias, Rosilene Oliveira } \\
\text { de Souza, Luiz Genédio Mendes Jorge e Alessandro } \\
\text { Aurélio Caldeira. }\end{array}$ \\
\hline $131 / 16$ & $\begin{array}{l}\text { Institui Grupo Assessor das Normas } \\
\text { Brasileiras de Contabilidade } \\
\text { Aplicadas ao Setor Público }\end{array}$ & $\begin{array}{l}\text { Zulmir Ivânio Breda, Gildernora Batista Dantas } \\
\text { Milhomem, Leonardo Silveira do Nascimento, Joaquim } \\
\text { Osório Liberalquino Ferreira, Renato Pontes Dias, } \\
\text { Rosilene Oliveira de Souza, Luiz Genédio Mendes Jorge, } \\
\text { Diego Rodrigues Boente, Bruno Ramos Mangualde, } \\
\text { Eder Sousa Vogado, Janilson Antonio Rocha, Felipe } \\
\text { Severo Bittencourt e Bruno Pires Dias. }\end{array}$ \\
\hline
\end{tabular}

Fonte: CFC, adaptado. 
ANEXO A - Histórico de Portarias que fixaram prazos de observância obrigatória dos procedimentos contábeis contidos no MCASP

\begin{tabular}{|c|c|c|c|c|c|c|c|}
\hline & $\begin{array}{l}\text { Portaria } n^{0} \\
467 / 2009(\text { texto } \\
\text { original })\end{array}$ & $\begin{array}{c}\text { Portaria } n^{\circ} \\
664 / 2010 \text { (texto } \\
\text { original) }\end{array}$ & $\begin{array}{l}\text { Portaria } n^{0} \\
406 / 2011(\text { texto } \\
\text { original) }\end{array}$ & $\begin{array}{c}\text { Portaria no } \\
828 / 2011\end{array}$ & $\begin{array}{c}\text { Portaria } n^{\circ} \\
437 / 2012 \text { (texto } \\
\text { original) }\end{array}$ & $\begin{array}{c}\text { Portaria } \mathbf{n}^{\mathbf{0}} \\
\text { 753/2012 } \\
\text { (alteração das } \\
\text { Portarias no } \\
\text { 437/2012 e } \mathbf{n}^{\mathbf{0}} \\
\text { 828/2011) } \\
\end{array}$ & $\begin{array}{c}\text { Portaria } \mathrm{n}^{\circ} \\
634 / 2013 \text { (texto } \\
\text { original) } \\
\text { Prazos atuais - } \\
\text { vigentes } \\
\text { integralmente }\end{array}$ \\
\hline PCASP & $\begin{array}{l}\text { 2011: União } \\
\text { 2012: Estados e } \\
\text { DF } \\
\text { 2013: Municípios }\end{array}$ & $\begin{array}{l}\text { 2012: União, } \\
\text { Estados e DF } \\
\text { 2013: Municípios }\end{array}$ & $\begin{array}{l}\text { 2012: União, } \\
\text { Estados e DF } \\
\text { 2013: Municípios }\end{array}$ & $\begin{array}{l}\text { 2013: União, } \\
\text { Estados, DF e } \\
\text { Municípios }\end{array}$ & $\begin{array}{l}\text { 2013: União, } \\
\text { Estados, DF e } \\
\text { Municípios }\end{array}$ & $\begin{array}{l}\mathbf{2 0 1 4} \\
\text { (integralmente até } \\
\text { o final do } \\
\text { exercício): União, } \\
\text { Estados, DF e } \\
\text { Municípios }\end{array}$ & $\begin{array}{l}\mathbf{2 0 1 4} \\
\text { (integralmente até } \\
\text { o final do } \\
\text { exercício): União, } \\
\text { Estados, DF e } \\
\text { Municípios }\end{array}$ \\
\hline DCASP & $\begin{array}{l}\text { 2011: União } \\
\text { 2012: os Estados e } \\
\text { DF } \\
\text { 2013: Municípios }\end{array}$ & $\begin{array}{l}\text { 2012: União, } \\
\text { Estados e DF } \\
\text { 2013: Municípios }\end{array}$ & $\begin{array}{l}\text { 2012: União, } \\
\text { Estados e DF } \\
\text { 2013: Municípios }\end{array}$ & $\begin{array}{l}\text { 2013: União, } \\
\text { Estados, DF e } \\
\text { Municípios }\end{array}$ & $\begin{array}{l}\text { 2013: União, } \\
\text { Estados, DF e } \\
\text { Municípios }\end{array}$ & $\begin{array}{l}\mathbf{2 0 1 4} \\
\text { (integralmente até } \\
\text { o final do } \\
\text { exercício): União, } \\
\text { Estados, DF e } \\
\text { Municípios }\end{array}$ & $\begin{array}{l}\mathbf{2 0 1 4} \\
\text { (integralmente até } \\
\text { o final do } \\
\text { exercício): União, } \\
\text { Estados, DF e } \\
\text { Municípios }\end{array}$ \\
\hline $\begin{array}{l}\text { Procedimentos } \\
\text { Contábeis } \\
\text { Patrimoniais - } \\
\text { PCP }\end{array}$ & $\begin{array}{l}\text { 2011: União } \\
\text { 2012: os Estados e } \\
\text { DF } \\
\text { 2013: Municípios }\end{array}$ & $\begin{array}{l}\text { 2011: União, } \\
\text { Estados, DF e } \\
\text { Municípios }\end{array}$ & $\begin{array}{l}\text { 2012: União, } \\
\text { Estados, DF e } \\
\text { Municípios }\end{array}$ & $\begin{array}{c}\mathbf{2 0 1 2} \\
\text { (gradualmente) } \\
\mathbf{2 0 1 4} \\
\text { (integralmente até } \\
\text { o final do } \\
\text { exercício): União, } \\
\text { Estados, DF e } \\
\text { Municípios }\end{array}$ & $\begin{array}{l}\mathbf{2 0 1 4} \\
\text { (integralmente até } \\
\text { o final do } \\
\text { exercício): União, } \\
\text { Estados, DF e } \\
\text { Municípios }\end{array}$ & $\begin{array}{l}\mathbf{2 0 1 4} \\
\text { (integralmente até } \\
\text { o final do } \\
\text { exercício): União, } \\
\text { Estados, DF e } \\
\text { Municípios }\end{array}$ & $\begin{array}{c}\text { Prazos a serem } \\
\text { definidos } \\
\text { conforme ato } \\
\text { normativo } \\
\text { específico da STN } \\
\text { para cada } \\
\text { procedimento }\end{array}$ \\
\hline $\begin{array}{l}\text { Procedimentos } \\
\text { Contábeis } \\
\text { Específicos - PCE }\end{array}$ & $\begin{array}{l}\text { 2011: União } \\
\text { 2012: os Estados e } \\
\text { DF } \\
\text { 2013: Municípios }\end{array}$ & $\begin{array}{l}\text { 2011: União, } \\
\text { Estados, DF e } \\
\text { Municípios }\end{array}$ & $\begin{array}{l}\text { 2012: União, } \\
\text { Estados, DF e } \\
\text { Municípios }\end{array}$ & $\begin{array}{l}\text { 2012: União, } \\
\text { Estados, DF e } \\
\text { Municípios }\end{array}$ & $\begin{array}{l}\text { 2013: União, } \\
\text { Estados, DF e } \\
\text { Municípios }\end{array}$ & $\begin{array}{l}\text { 2013: União, } \\
\text { Estados, DF e } \\
\text { Municípios }\end{array}$ & $\begin{array}{l}\text { 2013: União, } \\
\text { Estados, DF e } \\
\text { Municípios }\end{array}$ \\
\hline
\end{tabular}




\begin{tabular}{|c|c|c|c|c|c|c|c|}
\hline & $\begin{array}{l}\text { Portaria } n^{0} \\
467 / 2009(\text { texto } \\
\text { original) }\end{array}$ & $\begin{array}{l}\text { Portaria } \mathrm{n}^{0} \\
664 / 2010 \text { (texto } \\
\text { original) }\end{array}$ & $\begin{array}{l}\text { Portaria } n^{0} \\
406 / 2011(\text { texto } \\
\text { original) }\end{array}$ & $\begin{array}{c}\text { Portaria } \mathrm{n}^{\circ} \\
\mathbf{8 2 8 / 2 0 1 1}\end{array}$ & $\begin{array}{l}\text { Portaria }^{0} \\
437 / 2012 \text { (texto } \\
\text { original) }\end{array}$ & 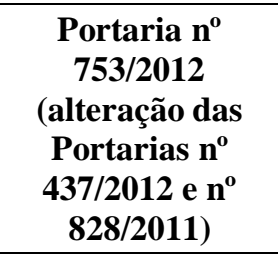 & $\begin{array}{c}\text { Portaria }^{\circ} \\
634 / 2013 \text { (texto } \\
\text { original) } \\
\text { Prazos atuais - } \\
\text { vigentes } \\
\text { integralmente } \\
\end{array}$ \\
\hline $\begin{array}{c}\text { Procedimentos } \\
\text { Contábeis } \\
\text { Orçamentários - } \\
\text { PCO } \\
\end{array}$ & $\begin{array}{l}\text { Aplicabilidade } \\
\text { imediata* }\end{array}$ & $\begin{array}{l}\text { Aplicabilidade } \\
\text { imediata* }\end{array}$ & $\begin{array}{l}\text { Aplicabilidade } \\
\text { imediata* }\end{array}$ & $\begin{array}{l}\text { Aplicabilidade } \\
\text { imediata* }\end{array}$ & $\begin{array}{l}\text { Aplicabilidade } \\
\text { imediata* }\end{array}$ & $\begin{array}{l}\text { Aplicabilidade } \\
\text { imediata* }\end{array}$ & $\begin{array}{l}\text { Aplicabilidade } \\
\text { imediata* }\end{array}$ \\
\hline
\end{tabular}

Fonte: Nota Técnica nº 5/2013/CCONF/SUCON/STN/MF-DF, adaptado. 


\section{ANEXO B - NBC TSP do Setor Público}

\begin{tabular}{|c|c|c|c|}
\hline & & & Correlação \\
\hline NBC & $\begin{array}{l}\text { Resolução } \\
\text { CFC }\end{array}$ & Nome da Norma & IFAC \\
\hline $\begin{array}{c}\text { NBC TSP } \\
\text { ESTRUTURA } \\
\text { CONCEITUAL }\end{array}$ & DOU 04/10/16 & $\begin{array}{l}\text { Estrutura Conceitual para Elaboração e Divulgação de Informação Contábil de Propósito Geral } \\
\text { pelas Entidades do Setor Público }\end{array}$ & $\begin{array}{l}\text { Conceptual } \\
\text { Framework }\end{array}$ \\
\hline NBC T 16.1 & $1.128 / 08$ & Conceituação, Objeto e Campo de Aplicação - revogada a partir de 1/1/17 & não há \\
\hline NBC T 16.2 & $1.129 / 08$ & Patrimônio e Sistemas Contábeis - revogada a partir de 1/1/17 & não há \\
\hline NBC T 16.3 & $1.130 / 08$ & Planejamento e seus Instrumentos sob o Enfoque Contábil - revogada a partir de 1/1/17 & não há \\
\hline NBC T 16.4 & $1.131 / 08$ & Transações no Setor Público - revogada a partir de 1/1/17 & não há \\
\hline NBC T 16.5 & $1.132 / 08$ & Registro Contábil - revogada a partir de 1/1/17 & não há \\
\hline NBC T $16.6 \mathrm{R} 1$ & DOU $31 / 10 / 14$ & Demonstrações Contábeis & não há \\
\hline NBC T 16.7 & $1.134 / 08$ & Consolidação das Demonstrações Contábeis & não há \\
\hline NBC T 16.8 & $1.135 / 08$ & Controle Interno & não há \\
\hline NBC T 16.9 & $1.136 / 08$ & Depreciação, Amortização e Exaustão & não há \\
\hline NBC T 16.10 & $1.137 / 08$ & Avaliação e Mensuração de Ativos e Passivos em Entidades do Setor Público & não há \\
\hline NBC T 16.11 & $1.366 / 11$ & Sistema de Informação de Custos do Setor Público & não há \\
\hline
\end{tabular}

Fonte: CFC, 2016. 
